\title{
Basisinformatie arbeidsmarkt en scholing voor de ambachten
}

Citation for published version (APA):

Cörvers, F., \& Borghans, L. (1998). Basisinformatie arbeidsmarkt en scholing voor de ambachten.

Researchcentrum voor Onderwijs en Arbeidsmarkt, Faculteit der Economische Wetenschappen. ROA Reports No. 6 https://doi.org/10.26481/umarep.1998006

Document status and date:

Published: 01/01/1998

DOI:

10.26481/umarep.1998006

Document Version:

Publisher's PDF, also known as Version of record

\section{Please check the document version of this publication:}

- A submitted manuscript is the version of the article upon submission and before peer-review. There can be important differences between the submitted version and the official published version of record.

People interested in the research are advised to contact the author for the final version of the publication, or visit the DOI to the publisher's website.

- The final author version and the galley proof are versions of the publication after peer review.

- The final published version features the final layout of the paper including the volume, issue and page numbers.

Link to publication

\footnotetext{
General rights rights.

- You may freely distribute the URL identifying the publication in the public portal. please follow below link for the End User Agreement:

www.umlib.nl/taverne-license

Take down policy

If you believe that this document breaches copyright please contact us at:

repository@maastrichtuniversity.nl

providing details and we will investigate your claim.
}

Copyright and moral rights for the publications made accessible in the public portal are retained by the authors and/or other copyright owners and it is a condition of accessing publications that users recognise and abide by the legal requirements associated with these

- Users may download and print one copy of any publication from the public portal for the purpose of private study or research.

- You may not further distribute the material or use it for any profit-making activity or commercial gain

If the publication is distributed under the terms of Article $25 \mathrm{fa}$ of the Dutch Copyright Act, indicated by the "Taverne" license above, 


\section{Basisinformatie arbeidsmarkt en scholing voor de ambachten}

F. Cörvers
L. Borghans

Researchcentrum voor Onderwijs en Arbeidsmarkt

Faculteit der Economische Wetenschappen en Bedrijfskunde Universiteit Maastricht

Maastricht, maart 1998 
ISBN 90-5321-230-2

SEC98.048/FC 


\section{Inhoud}

Bladzijde

1 Inleiding 1

2 Schoolverlaters tussen opleiding en ambacht $\quad 11$

3 Kenmerken van werkenden in ambachtelijke branches 35

4 Arbeidsmarktperspectieven voor de ambachten 55

$\begin{array}{ll}5 \text { Conclusies } & 71\end{array}$

$\begin{array}{ll}\text { Literatuur } & 77\end{array}$

$\begin{array}{ll}\text { Bijlage A } & 79\end{array}$

$\begin{array}{lr}\text { Bijlage B } & 83\end{array}$

$\begin{array}{ll}\text { Bijlage C } & 95\end{array}$ 



\section{Inleiding}

Ambachtelijk vervaardigde producten en ambachtelijke dienstverlening staan in het dagelijkse leven voor degelijkheid, echtheid en vakbekwaamheid. Het ambacht staat tegenwoordig voor veel meer dan 'oude ambachten', omdat toenemende massaproductie voor de consumentenmarkt ertoe heeft geleid dat het ambacht zich meer is gaan toeleggen op zowel maatwerk als onderhoud en dienstverlening. Door voortschrijdende technologische ontwikkelingen, veranderende arbeidsomstandigheden en hogere eisen op het gebied van milieu, gezondheid en kwaliteit wordt een steeds groter beroep gedaan op het vakmanschap en de creativiteit van werknemers en zelfstandige ondernemers in het ambacht. Goed ondernemerschap en hoogwaardige kwaliteit van producten en diensten in een dynamische omgeving stellen hoge eisen aan de beschikbaarheid en kwalificaties van werkenden in het ambacht. Het is derhalve van groot belang zicht te krijgen op de beschikbaarheid van goed opgeleide arbeidskrachten voor het ambacht.

Een belangrijk gedeelte van het ambacht in Nederland wordt vertegenwoordigd door het Hoofdbedrijfschap Ambachten (HBA). Het HBA is een publiekrechtelijke bedrijfsorganisatie gericht op ondernemers en werknemers die in het ambacht werken. Het HBA is in het bijzonder belast met het sociaal-economisch beleid van het ambacht. Eén van de kernthema's van het HBA is arbeidsmarkt en scholing. Het HBA ontplooit onder andere initiatieven om vraag en aanbod op de arbeidsmarkt voor het ambacht beter op elkaar te laten aansluiten en de werkgelegenheid in het ambacht te bevorderen.

Het HBA omvat 38 ambachtelijke branches (zie bijlage A) die gezamenlijk ongeveer 52.000 ondernemingen en een kwart miljoen arbeidsplaatsen vertegenwoordigen. De relevantie van voldoende en goed opgeleide arbeidskrachten voor deze ambachten is hierboven al aangegeven. Met het oog hierop wordt in dit rapport kwantitatieve informatie gegeven over de relevante opleidingen en beroepen voor de ambachten die bij het HBA zijn aangesloten en de aansluiting tussen deze opleidingen en beroepen. Daarnaast wordt getracht zicht te krijgen op de kenmerken van de werkenden en de door hen bezette arbeidsplaatsen in het ambacht wat betreft bijvoorbeeld geslacht, afkomst en deeltijdwerk. Het inzicht in deze kenmerken is zinvol vanwege maatschappelijke en politieke voorkeuren omtrent de bevordering van de arbeidsparticipatie van vrouwen en allochtonen en de bevordering van deeltijdwerk en zelfstandig ondernemerschap.

De significante betekenis van alle ambachtelijke branches tezamen voor de Nederlandse economie blijkt uit de omzet van 72 miljard gulden die zij in 1995 realiseerden en de hiermee gepaard gaande werkgelegenheid van 308.000 arbeidsjaren (zie EIM, 1997). Hoewel het ambacht verantwoordelijk was voor slechts $6 \%$ van de totale omzet van het particuliere bedrijfsleven in 1995, behoorde maar liefst $22 \%$ van de ondernemingen in het particuliere bedrijfsleven tot de ambachtelijke branches 
(volgens de afbakening van het EIM, 1997), hetgeen de kleinschaligheid van deze ondernemingen illustreert. Voorts nam het ambacht $9 \%$ van het totale aantal arbeidsjaren van het particuliere bedrijfsleven voor zijn rekening, hetgeen de hoge arbeidsintensiteit van het ambacht illustreert ${ }^{1}$. Bovenstaande gegevens illustreren de twee sleutelbegrippen die het ambacht volgens de omschrijving in het Jaarboek Ambacht 1996-1997 (EIM, 1997) kenmerken, namelijk de kleinschaligheid en de handmatige aard van de productiewijze $e^{2}$. Het aanzienlijke aandeel van de ambachtelijke branches in de werkgelegenheid van het Nederlandse bedrijfsleven is reden te meer om vraag en aanbod op de arbeidsmarkt voor de ambachten nader te onderzoeken.

\section{Afbakening van de ambachten}

In dit rapport worden de ambachten gedefinieerd door uit te gaan van de ambachtelijke brancheverenigingen die zijn aangesloten bij het HBA (zie bijlage A). De branches behorende tot het HBA vallen elk onder één of meerdere bedrijfsklassen uit de Standaard Bedrijfsindeling 1993 van het Centraal Bureau voor de Statistiek (CBS). Verder zijn er ten behoeve van dit rapport voor elke branche bijbehorende beroepen vastgesteld uit de Standaard Beroepenclassificatie 1992 van het CBS (zie bijlage B). Met behulp van deze twee classificaties van het CBS kan in beginsel elk ambacht worden afgebakend. Voor een aantal ambachten komen de bedrijfsklasse en het beroep vrijwel overeen, bijvoorbeeld in het tandtechnisch laboratorium bedrijf. In de bedrijfsklasse Tandtechnische bedrijven (SBI 3310.1) werken vooral tandtechnici en tandprothetici (zie paragraaf 3.30). Een beperkt aantal werkenden in deze bedrijfsklasse heeft een ander beroep, bijv. secretaresse of schoonmaker.

Andere ambachten omvatten meerdere bedrijfsklassen of beroepen, zijn in één bedrijfsklasse ondergebracht met andere economische activiteiten uit de Standaard Bedrijfsindeling of zijn in één beroepsklasse ondergebracht met andere beroepen uit de Standaard Beroepenclassificatie. Voor vele ambachten geldt er een andere combinatie van bedrijfsklasse en beroep. Voor sommige ambachten geldt echter dat de werkenden met behulp van de twee genoemde classificaties van het CBS niet te onderscheiden zijn van de werkenden in andere ambachten of beroepen ${ }^{3}$. Zo zijn de voetverzorgers (voetverzorgingsbedrijf, paragraaf 2.35) niet te onderscheiden van de

1. Deze cijfers zijn afkomstig uit EIM (1997, tabel 1).

2. De Werkgroep Onderzoekplan, die in 1980 door het Hoofdbedrijfschap Ambachten werd ingesteld, gaf de volgende omschrijving van het ambacht: "In overwegende mate ondernemingen, behorende tot het midden- en kleinbedrijf, die producerende, installerende, reparerende en dienstverlenende functies verrichten, met het doel te voorzien in de vraag naar behoeftebevredigingsmiddelen van individuele aard."

3. In dit geval kan het aantal werkenden dat bij een ambacht vermeld staat, werkenden uit andere bedrijfsklassen en beroepen omvatten. De procentuele aandelen van de kenmerken (bijvoorbeeld opleidingsachtergrond en leeftijd) van deze werkenden worden geacht niet te verschillen van de procentuele aandelen van de kenmerken van de werkenden in het ambacht. 
manicures (niet bij het HBA aangesloten), omdat beide onder dezelfde bedrijfsklasse (Schoonheidsverzorging, voetverzorgers en manicures, SBI9302.2) en onder hetzelfde beroep (Manicure, voetverzorger, kappershulp, schoonheidsmasseur sauna, SBC 37210) vallen. In dit voorbeeld zijn de voetverzorgers wel te onderscheiden van de schoonheidsverzorgers, omdat beide weliswaar onder dezelfde bedrijfsklasse vallen, maar de schoonheidsverzorgers onder een ander beroep vallen (Kapper, pruikenmaker, grimeur, schoonheidsspecialist, SBC 57212) ${ }^{4}$.

\section{Aansluiting tussen opleiding en ambacht}

Met betrekking tot de aansluiting tussen opleiding en ambacht kunnen er verschillende situaties worden onderscheiden. Ten eerste bestaan er voor een aantal ambachten regulier bekostigde opleidingen. Deze opleidingen kunnen behoren tot het voltijds onderwijs (bijvoorbeeld VBO Consumptieve techniek Banketbakken) of tot het leerlingwezen (bijvoorbeeld Primair Goud-en Zilversmid). Voor een aanzienlijk aantal ambachten zijn er echter geen regulier bekostigde opleidingen (bijvoorbeeld voor het consumptie-ijsbereidingsbedrijf). Niettemin is het mogelijk dat er in ambachten waarvoor geen regulier bekostigde opleidingen bestaan (gedefinieerd door branche en/of beroep) relatief veel schoolverlaters met een bepaalde opleiding gaan werken (eventueel in het leerlingwezen) zonder dat deze opleiding gericht is op het betreffende ambacht. In het algemeen zal echter blijken dat er een grote diversiteit is van de opleidingsachtergrond van werkenden in ambachten die een regulier bekostigd opleidingenstelsel ontberen.

Ter illustratie van deze diversiteit voor een ambacht zonder regulier bekostigd opleidingenstelsel geeft tabel 1.1 de opleidingsachtergrond van schoolverlaters uit het schooljaar 1993/'94 weer die in 1995 (het enquêtejaar) werkten in het consumptieijsbereidingsbedrijf. Het aantal schoolverlaters uit de steekproef die in 1995 in het consumptie-ijsbereidingsbedrijf werkten bedroeg slechts vijf. Uit de tabel blijkt dat er vijf verschillende opleidingsrichtingen zijn onder de vijf werkende schoolverlaters. Het percentage van $20 \%$ in tabel 1.1 is dus gebaseerd op één schoolverlater. Het is duidelijk dat het aantal werkende schoolverlaters in het consumptie-ijsbereidingsbedrijf te gering is om conclusies te trekken over hun specifieke opleidingsachtergrond ${ }^{5}$. Het is echter wel gerechtvaardigd de conclusie te trekken dat de opleidingsachtergrond van werkende schoolverlaters in het consumptie-ijsbereidingsbedrijf een grote diversiteit vertoont en dat er een zwakke aansluiting is tussen opleiding en beroep in het consumptie-ijsbereidingsbedrijf.

4. In de genoemde CBS-indelingen staan 'voetverzorgers' genoemd als 'pedicures'. De branchevereniging voor het voetverzorgingsbedrijf prefereert het gebruik van de term 'voetverzorgers' boven 'pedicures'. Derhalve is de term 'pedicures' in dit rapport overal vervangen door de term 'voetverzorgers'.

5. Tabellen die gebaseerd zijn op minder dan 25 schoolverlaters zullen niet gepresenteerd worden (zie paragraaf 2.1). 
Tabel 1.1

Opleidingsachtergrond van werkende schoolverlaters in het consumptie-ijsbereidingsbedrijf (SBI 1552, 5530.3)

\begin{tabular}{lc}
\hline Opleidingsrichting & $\%$ \\
\hline KMBO oriënterende schakel & 20 \\
MBO-tussen Veehouderij & 20 \\
MBO Dierenverzorging & 20 \\
MBO Horeca & 20 \\
MBO Toerisme en recreatie & 20 \\
\hline
\end{tabular}

Bron: ROA

Ten tweede is het niet op voorhand gegarandeerd dat schoolverlaters met een regulier bekostigde, ambachtelijke opleiding gaan werken in de bijbehorende ambachten (al dan niet in het leerlingwezen). Enerzijds kunnen de betreffende opleidingen voldoende uitwijkmogelijkheden bieden voor de schoolverlater om te gaan werken in andere branches of beroepen. Het is bijvoorbeeld goed denkbaar dat schoolverlaters met een bakkers- of slagersopleiding niet alleen gaan werken als verkoper in een bakkerij of slagerij, maar ook elders in de detailhandel als verkoper. Anderzijds kunnen er voor de werkgever voldoende andere substitutiemogelijkheden zijn voor het in dienst nemen van de schoolverlater met de bij het ambacht behorende regulier bekostigde opleiding. Met andere woorden, de aansluiting op de arbeidsmarkt tussen de opleidingsachtergrond en de beroepsuitoefening van werkenden in de ambachten kan geheel anders zijn dan de formele aansluiting.

Op basis van de twee bovengenoemde indicatoren, namelijk het bestaan van een regulier bekostigde opleiding en de aansluiting tussen opleiding en beroep, zal het arbeidsmarktprofiel van een ambacht worden vastgesteld. Bovendien zal het arbeidsmarktperspectief van een ambacht worden bepaald op basis van de arbeidsmarktperspectieven van opleidingen en beroepen die veelvulding in het betreffende ambacht voorkomen.

\section{Opbouw van het rapport}

De verdere opbouw van dit rapport is als volgt. In hoofdstuk 2 wordt ingegaan op de positie van schoolverlaters die hetzij een regulier bekostigde ambachtelijke opleiding hebben genoten, hetzij in een ambachtelijke branche (bijlage A) of in een ambachtelijk beroep (bijlage B) zijn gaan werken ${ }^{6}$. Voor elke ambacht wordt vermeld of er regulier bekostigde opleidingen voor een ambacht zijn. Indien dit het geval is wordt bekeken in welke mate deze opleidingen onder de schoolverlaters voorkomen en wat het diplomabezit is van deze schoolverlaters. Voor deze regulier bekostigde ambachtelijke opleidin-

6. In het vervolg van dit rapport worden alleen de ambachtelijke branches, opleidingen of beroepen bedoeld van de ambachten die aangesloten zijn bij het HBA. 
gen wordt nagegaan wat de bestemming is van schoolverlaters. Dit betekent dat wordt nagegaan welke de belangrijkste vervolgopleidingen in het regulier bekostigde voltijds onderwijs of in het leerlingwezen zijn en welke de belangrijkste beroepen zijn die worden uitgeoefend met de betreffende ambachtelijke opleiding. Verder zal de aansluiting tussen opleiding en beroep worden uitgedrukt met behulp van de waardering van de aansluiting door schoolverlaters. Indien er geen regulier bekostigde opleidingen (voltijds onderwijs of leerlingwezen, zie ook de definitie in hoofdstuk 1) voor het ambacht bestaan wordt nagegaan welke opleidingen het meest voorkomen onder de schoolverlaters die in het betreffende ambacht gaan werken. Ook wordt een indicatie van het diplomabezit en van de kwaliteit van de aansluiting tussen opleiding en beroep van deze schoolverlaters gegeven. De bestemming, de aansluiting tussen opleiding en beroep en het diplomabezit van de schoolverlaters van regulier bekostigde en nietregulier bekostigde opleidingen zal, voor zover de data het toelaten, worden afgezet tegen het gemiddelde voor de totale groep van schoolverlaters (zie bijlage $C$ ). De gegevens die gebruikt worden voor de schoolverlaters-analyse in dit hoofdstuk zijn afkomstig van de enquête Registratie van Uitstroom en Bestemming van Schoolverlaters (RUBS) die in het voorjaar van 1995 is gehouden onder schoolverlaters van het schooljaar 1993/ 1994 van het Algemeen Voortgezet Onderwijs (AVO), het Voorbereidend Beroepsonderwijs (VBO) en de korte, tussen en lange variant van het Middelbaar Beroepsonderwijs (MBO) ${ }^{7}$.

Ten tweede wordt in hoofdstuk 3 ingegaan op de relevante arbeidsmarktgegevens van de ambachtelijke branches die zijn aangesloten bij het HBA. Deze gegevens laten zien wie er in de ambachtelijke branches werkzaam zijn met betrekking tot de opleidingsachtergrond, het uitgeoefende beroep, het geslacht, de leeftijd en de etnische achtergrond. Voorts worden de arbeidsrelaties van de werkzame personen in beeld gebracht door het aandeel zelfstandigen, het aandeel werkenden met een flexibel of vast contract en het aandeel deeltijders per branche weer te geven. Hierbij zullen de kenmerken van de werkzame personen wat betreft opleiding, beroep, geslacht, etc. in een ambacht worden vergeleken met de gemiddelden voor alle ambachten aangesloten bij het HBA en de gemiddelden in de totale beroepsbevolking (zie bijlage $C$ ). De gegevens voor deze branche-analyse zijn afkomstig van de Enquête Beroepsbevolking van het CBS $(1995,1996)$.

Het derde onderdeel van dit rapport wordt gepresenteerd in hoofdstuk 4 en betreft een analyse van de arbeidsmarktperspectieven van de ambachten. Uit de voorgaande hoofdstukken is dan duidelijk geworden welke de belangrijkste opleidingen, beroepen en bedrijfsklassen zijn voor een ambacht. In het rapport Arbeidsmarkt naar opleiding en beroep tot 2000 (ROA, 1995, 1996) zijn prognoses opgenomen voor elk van deze afzonderlijke opleidingen, beroepen en bedrijfsklassen. Op basis hiervan kan voor een

7. Zie het rapport Schoolverlaters tussen onderwijs en arbeidsmarkt $\left(\mathrm{ROA}, 1996^{\mathrm{a}}\right)$ voor nadere informatie over de schoolverlaters-enquête. 
ambacht een indicatie gegeven worden wat de arbeidsmarktperspectieven zijn van de bijhorende ambachtelijke opleidingen en wat de verwachte groei is in aantal werkzame personen van de bijbehorende ambachtelijke beroepen. Door aan te geven in welke beroepssegmenten de werkgelegenheidsmogelijkheden voor een bepaalde opleidingscategorie zich met name manifesteren kan ook een beeld worden geschetst van de alternatieven die werkenden in de ambachten wellicht hebben.

Dit rapport sluit af met een concluderend hoofdstuk. Op basis van de informatie in de hoofdstukken 2, 3 en 4 zal in hoofdstuk 5 een samenvattend overzicht worden gegeven van zowel het arbeidsmarktprofiel als het arbeidsmarktperspectief van de ambachten die aangesloten zijn bij het HBA.

Verklaring van gebruikte begrippen

Hieronder volgen de omschrijvingen van de in dit rapport gebruikte begrippen. Een specifieke toelichting op de gehanteerde begrippen is te vinden in Borghans et al. $\left(1995,1995^{a}\right)$. Bij een aantal begrippen zijn de grenswaarden voor de kwalitatieve typeringen weergegeven (zie Borghans et al., 1995).

\section{Aansluiting}

De aansluiting tussen opleiding en beroep van werkende schoolverlaters wordt in dit rapport beoordeeld op basis van drie indicatoren. De schoolverlaters wordt gevraagd naar de benutting in hun huidige beroep van de kennis en vaardigheden die ze hebben opgedaan tijdens de opleiding, naar de aansluiting tussen opleiding en beroep en of er een vakrichting vereist werd voor het uitoefenen van het beroep.

\section{Allochtoon}

Het begrip allochtoon wordt in dit rapport gehanteerd volgens de CBS-definitie. Deze definitie houdt in dat iedereen die een niet-Nederlandse nationaliteit bezit, of die buiten Nederland is geboren, allochtoon is.

\section{Baanopeningen}

Het aantal baanopeningen weerspiegelt de totale vraag naar nieuwkomers op de arbeidsmarkt. Deze wordt bepaald door de som van de (positieve) uitbreidingsvraag en de vervangingsvraag. Indien het vertrek van werkenden niet leidt tot het aannemen van nieuwkomers wordt dit niet meegerekend bij de vervangingsvraag. Met andere woorden, de vervangingsvraag is gelijk aan de uitstroom van werkenden voor zover deze uitstroom daadwerkelijk vervangen wordt. Alleen deze banen komen immers beschikbaar voor nieuwkomers. Op vergelijkbare wijze heeft een negatieve uitbreidingsvraag (werkgelegenheidskrimp) geen directe invloed op de vraag naar nieuwkomers op 
de arbeidsmarkt. Bij de baanopeningen is daarom alleen de positieve uitbreidingsvraag van belang. Het totaal aantal baanopeningen is bij een negatieve uitbreidingsvraag dus gelijk aan de vervangingsvraag. De grenswaarden en de kwalitatieve typeringen voor de verwachte baanopeningen bij beroepsklassen zijn als volgt: beneden 12 is erg laag, tussen 12 en 17 is laag, tussen 17 en 31 is gemiddeld, tussen 31 en 44 is hoog, boven 44 is erg hoog. De grenswaarden en de kwalitatieve typeringen voor de verwachte baanopeningen bij opleidingen zijn als volgt: beneden 9 is erg laag, tussen 9 en 15 is laag, tussen 15 en 29 is gemiddeld, tussen 29 en 42 is hoog, boven 42 is erg hoog.

\section{Benutting}

De benuttting heeft betrekking op de verhouding tussen het werkelijke opleidingsniveau van een werkende en het vereiste opleidingsniveau van de uitgeoefende functie. Van onderbenutting is sprake als het opleidingsniveau dat minimaal vereist is voor de functie lager is dan het feitelijke opleidingsniveau.

\section{Diploma-bezit}

De indicator voor het diplomabezit is gebaseerd op het percentage schoolverlaters dat een opleiding met een diploma heeft afgesloten. Dit percentage gedeeld door 10 en afgerond op één cijfer is gelijk aan de diploma-indicator. Het percentage wordt niet gepresenteerd om te voorkomen dat het percentage wordt geïnterpreteerd als rendementcijfer van opleidingen. Het percentage diplomahouders is daarvoor niet geëigend omdat de respons van niet-diplomahouders in de schoolverlatersenquête niet betrouwbaar is. Het diplomabezit van schoolverlaters is laag bij een indicator van 7 , gemiddeld bij een indicator van 9 en hoog bij een indicator van 10 .

\section{Flexibele arbeidsrelatie}

Van een flexibele arbeidsrelatie is sprake bij uitzendkrachten, oproepkrachten, invalskrachten, contracten zonder een vast aantal arbeidsuren en indien geen vast dienstverband is overeengekomen. Een arbeidscontract wordt als niet-vast beschouwd als de contractuele termijn korter is dan een jaar en er geen vooruitzicht is op een vast dienstverband.

\section{Indicator toekomstige arbeidsmarktsituatie (ITA)}

De Indicator Toekomstige Arbeidsmarktsituatie geeft het toekomstig arbeidsmarktperspectief per opleiding weer. Deze indicator is gedefieerd als de verhouding tussen enerzijds de verwachte instroom van schoolverlaters en het aantal kortdurig werklozen en anderzijds de verwachte baanopeningen en de substitutievraag. Naarmate de waarde van de indicator hoger is wordt het perspectief slechter. Bij 1,00 of lager wordt de ITA als goed getypeerd, van 1,01 tot en met 1,05 als redelijk, van 1,06 tot en met 
1,15 als matig en boven 1,15 als slecht.

\section{Instroom van schoolverlaters}

Het aanbod van nieuwe arbeidskrachten op de arbeidsmarkt, zoals deze is bepaald door de verwachte uitstroom van schoolverlaters uit het initiele onderwijs, de schoolverlaters van het deeltijdonderwijs, het niet-regulier bekostigde voltijdonderwijs en de beroepsgerichte volwasseneducatie. De grenswaarden en de kwalitatieve typeringen voor de verwachte instroom bij opleidingen zijn als volgt: beneden 4 is erg laag, tussen 4 en 14 is laag, tussen 14 en 28 is gemiddeld, tussen 28 en 38 is hoog, boven 38 is erg hoog.

\section{Leerlingwezen}

Het LDC et al. (1994) beschrijft het leerlingwezen als volgt (blz. 11): "Het leerlingwezen is een duaal opleidingssysteem van werken en leren tegelijk. Werkend leren betekent dat de cursisten in de beroepspraktijk (in een bedrijf of instelling) worden opgeleid en aanvullend theorie-onderwijs volgen op een school voor Cursorisch Beroeps Onderwijs (cbo). Het theorie-onderwijs bestaat in de regel uit beroepsgericht en algemeen vormend onderwijs. In het algemeen geldt dat een cursist drie à vier dagen in een bedrijf werkt en één dag per week naar school gaat. In het bedrijf wordt een cursist begeleid door een ervaren vakkracht die als praktijkbegeleider fungeert." In de nieuwe wetgeving (WEB) wordt in plaats van het leerlingwezen gesproken over 'Beroepsbegeleidende Leerweg'.

\section{Onderbenutting}

Van onderbenutting is sprake als het opleidingsniveau dat minimaal vereist is voor de functie lager is dan het feitelijke opleidingsniveau.

\section{Regulier bekostigde opleiding}

Onder regulier bekostigde opleidingen worden in dit rapport verstaan opleidingen in het voltijds onderwijs of opleidingen in het kader van het leerlingwezen.

\section{Substitutievraag}

Schoolverlaters in een aanbodoverschotsituatie kunnen anders opgeleiden gaan verdringen, terwijl werkgevers die te kampen hebben met een tekortschietend arbeidsaanbod, personen met een andere opleidingsachtergrond kunnen gaan werven. De vraag die hierdoor verloren gaat of ontstaat wordt aangeduid als de substitutievraag. Een grotere substitutievraag draagt bij tot een beter arbeidsmarktperspectief. 


\section{Uitbreidingsvraag}

De vraag naar nieuwe arbeidskrachten die ontstaat door groei van de werkgelegenheid. Als er sprake is van een werkgelegenheidsdaling, is de uitbreidingsvraag negatief. De grenswaarden en de kwalitatieve typeringen voor de verwachte uitbreidingsvraag bij beroepsklassen zijn als volgt: beneden -12 is erg laag, tussen -12 en -3 is laag, tussen -3 en 8 is gemiddeld, tussen 8 en 17 is hoog, boven 17 is erg hoog. De grenswaarden en de kwalitatieve typeringen voor de verwachte uitbreidingsvraag bij opleidingen zijn als volgt: beneden -7 is erg laag, tussen -7 en 3 is laag, tussen 3 en 13 is gemiddeld, tussen 13 en 23 is hoog, boven 23 is erg hoog.

\section{Uitwijkmogelijkheden}

De mate waarin arbeidskrachten met een bepaalde opleidingsachtergrond terecht kunnen komen in andere beroepsgroepen op een aansluitend of hoger functieniveau. Deze maatstaf geeft daarmee aan in hoeverre arbeidskrachten afhankelijk zijn van de arbeidsmarktsituatie in een bepaald beroep.

\section{Vervangingsvraag}

De vraag naar nieuwe arbeidskrachten die ontstaat doordat de arbeidsplaatsen van werkenden die met pensioen gaan, arbeidsongeschikt worden of zich (tijdelijk) terugtrekken van de arbeidsmarkt opnieuw moeten worden opgevuld. Vertrek van werkenden dat niet leidt tot vraag naar nieuwkomers uit hetzelfde opleidingstype wordt niet meegerekend als vervangingsvraag (zie verder de toelichting onder baanopeningen). De grenswaarden en de kwalitatieve typeringen voor de verwachte vervangingsvraag bij beroepsklassen zijn als volgt: beneden 12 is erg laag, tussen 12 en 17 is laag, tussen 17 en 23 is gemiddeld, tussen 23 en 28 is hoog, boven 28 is erg hoog. De grenswaarden en de kwalitatieve typeringen voor de verwachte vervangingsvraag bij opleidingen zijn als volgt: beneden 9 is erg laag, tussen 9 en 12 is laag, tussen 12 en 16 is gemiddeld, tussen 16 en 19 is hoog, boven 19 is erg hoog.

\section{Zelfstandige}

Personen die werkzaam zijn in eigen bedrijf of praktijk of in het bedrijf of de praktijk van hun partner of ouders. Daarnaast worden tot de zelfstandigen gerekend personen die niet werknemer zijn en niet werkzaam zijn in eigen bedrijf of praktijk van hun partner of ouders (bijvoorbeeld freelancers). 


\section{Schoolverlaters tussen opleiding en ambacht}

Dit hoofdstuk kenschetst de bestemming van schoolverlaters die een min of meer ambachtelijke opleiding hebben genoten of die in een ambacht gaan werken na het verlaten van hun opleiding. De bestemming van schoolverlaters na het verlaten van de (voor)opleiding kan zijn een betaalde baan, maar kan een vervolgopleiding of een plaats in het leerlingwezen (LLW). Uit tabel C.1 in bijlage $C$ blijkt dat van alle schoolverlaters in de schoolverlatersenquête ongeveer tweederde verder studeert, ongeveer eenvijfde een betaalde baan buiten het leerlingwezen krijgt en ongeveer eentiende een leerlingplaats krijgt.

In dit hoofdstuk wordt de bestemming van schoolverlaters in de enquête vergeleken met de bestemming van schoolverlaters van de ambachtelijke opleidingen ${ }^{8}$. Verder wordt per ambacht een beeld van de belangrijkste opleidingen of beroepen gegeven. Daarnaast wordt per ambacht ingegaan op de kwaliteit van de aansluiting tussen opleiding en beroep. Daartoe wordt het vereiste opleidingsniveau van het betaalde werk, de inhoudelijke aansluiting tussen opleiding en beroep en de vereiste vakkennis van de groep schoolverlaters van ambachtelijke opleidingen vergeleken met schoolverlaters in het algemeen (zie tabel C.2 in bijlage C).

Uit dit hoofdstuk zal blijken dat er in sommige ambachten relatief veel en in andere ambachten nauwelijks schoolverlaters terecht komen. Het aantal schoolverlaters dat gaat werken in een ambacht kan een indicatie zijn voor de mate waarin deze ambachten nieuw of jong personeel aannemen ${ }^{9}$. De onderdelen waarvoor niet voldoende gegevens bekend zijn zullen niet worden opgenomen in het overzicht, zonder dat dit steeds expliciet zal worden vermeld ${ }^{10}$. Een vermelding van een opleiding of andere bezigheid wordt alleen gegeven als er minimaal drie schoolverlaters geregistreerd staan die minimaal $10 \%$ van de totale groep uitmaken. Voor sommige onderdelen geldt dat er juist additionele informatie uit de schoolverlatersenquête te verkrijgen

8. De schoolverlaters-enquête is in het voorjaar van 1995 gehouden onder schoolverlaters van het schooljaar 1993/ 1994 (zie hoofdstuk 1). De gepresenteerde gegevens hebben, tenzij anders vermeld, betrekking op zowel gediplomeerde als ongediplomeerde schoolverlaters. In bijlage $\mathrm{C}$ zijn voor diverse variabelen van dit hoofdstuk de percentages van de gehele steekproef van schoolverlaters (meer dan 13.000) opgenomen.

9. De schoolverlatersenquête omvat overigens alleen de instroom van schoolverlaters in het leerlingwezen, en niet de uitstroom van schoolverlaters uit het leerlingwezen op de arbeidsmarkt (zie ROA, 1996').

10. Zie voor alle opleidingen binnen het $M B O$ en het Leerlingwezen de Studiegids van het $M B O$ en Leerlingwezen 1994 en Studiegids van het MBO en Leerlingwezen 1995 van het LDC et al. $(1993,1994)$. 
is. In dat geval wordt een aanvullende tabel met toelichting gegeven ${ }^{11}$.

\section{Banketbakkersbedrijf}

\section{Vooropleidingen}

Voor het banketbakkersbedrijf bestaan er diverse regulier bekostigde voltijds dagopleidingen. Dit zijn naast de opleidingen die genoemd worden in tabel 2.1 ook de opleidingen KMBO CT Brood en banket, MBO-kort Uitvoerend medewerker ambachtelijk brood en banket, MTO Brood en banket en MBO Brood en banketbakken ${ }^{12}$. De opleidingen die niet genoemd zijn in de tabel komen niet voor onder de schoolverlaters in de schoolverlatersenquête. Tabel 2.1 laat zien dat het grootste aandeel van de schoolverlaters afkomstig is van het VBO CT Brood-en banketbakken ${ }^{13}$, gevolgd door het VBO CT Banketbakken en het MBO-kort Brood- en banketbakken. Op basis van de steekproef wordt het totale aantal schoolverlaters in Nederland (schooljaar 1993/'94) met een diploma van één van de opleidingen van tabel 2.1 op ongeveer 1750 geschat.

Tabel 2.1

Vooropleidingen voor het banketbakkersbedrijf

\begin{tabular}{lr}
\hline Opleidingsrichting & $\%$ \\
\hline VBO CT Brood- en banketbakken & 60 \\
VBO CT Banketbakken & 34 \\
MBO-kort Brood- en banketbakken & 5 \\
Totaal & 100
\end{tabular}

Bron: ROA

Tabel 2.2

Diplomabezit van schoolverlaters met een opleiding voor het banketbakkersbedrijf

\begin{tabular}{ll}
\hline Opleidingsrichting Indicator \\
\hline
\end{tabular}

VBO CT Brood- en banketbakken

VBO CT Banketbakken

10

MBO-kort Brood- en banketbakken

Bron: ROA

11. Tabellen zijn gebaseerd op gewogen aantallen. De tabellen worden alleen gepresenteerd als de totale aantal (ongewogen) schoolverlaters van de groep waarop de tabel betrekking heeft minimaal 25 bedraagt.

12. Omdat er vastgestelde opleidingen voor het banketbakkersbedrijf te zijn, worden alleen gegevens van gediplomeerde schoolverlaters met een brood- en banketbakkersopleiding gepresenteerd (tenzij anders vermeld).

13. De afkorting CT staat voor Consumptieve Techniek. 
De indicatie van het diplomabezit van schoolverlaters van deze opleidingen is volgens tabel 2.2 hoog voor het VBO CT Brood- en banketbakken en het VBO CT Banketbakken, namelijk respectievelijk 10 en 9 . Dit is iets hoger dan gemiddeld voor de eerste opleiding en komt ongeveer overeen met het gemiddelde diplomabezit van schoolverlaters voor de laatste opleiding ${ }^{14}$. Alleen de schoolverlaters van de opleiding MBO-kort Brood- en banketbakken scoort wat betreft het diplomabezit van schoolverlaters, zoals meestal bij het MBO-kort, lager dan gemiddeld.

\section{Bestemming van schoolverlaters}

Ongeveer driekwart van de schoolverlaters uit de genoemde richtingen kiest volgens tabel 2.3 na het verlaten van de opleiding voor een vervolgopleiding, hetzij in een regulier bekostigde dagopleiding, hetzij in het leerlingwezen. Het percentage van de schoolverlaters met een opleiding voor het banketbakkersbedrijf dat verder leert in het leerlingwezen is zeer hoog ten opzichte van de totale steekproef van schoolverlaters (zie bijlage C). Er bestaan in dit opzicht geen grote verschillen tussen de schoolverlaters van vooropleidingen voor het banketbakkersbedrijf met betrekking tot hun bestemming.

Tabel 2.3

Bestemming van schoolverlaters met een opleiding voor het banketbakkersbedrijf

\begin{tabular}{lrrrrr}
\hline Opleidingsrichting & scholier/ & $\begin{array}{r}\text { betaald } \\
\text { student } \\
\%\end{array}$ & $\begin{array}{r}\text { LLW } \\
\text { werk } \\
\%\end{array}$ & werkloos & anders \\
\hline $\begin{array}{l}\text { Gemiddelde (gewogen) } \\
\text { over opleidingen }\end{array}$ & 36 & 13 & 41 & 7 & 3 \\
\hline
\end{tabular}

\section{Bron: ROA}

\section{Vervolgopleidingen buiten het leerlingwezen}

De percentages van de schoolverlaters die na het volgen van een opleiding tot brooden banketbakker een vervolgopleiding buiten het leerlingwezen gaan doen worden weergeven in tabel 2.4. Slechts ongeveer tweevijfde van deze schoolverlaters volgt een opleiding die gerelateerd is aan hun vooropleiding in het brood en banket (MBO Brooden banketbakken, MBO-kort Brood- en banketbakken, MTO brood banket, KMBO CT Brood en banket). Dit betekent dat een heel groot deel van de schoolverlaters met vooropleiding in het brood en banket dat verder leert in een voltijdse opleiding van schoolverlaters met een opleiding voor het banketbakkersbedrijf, kiest voor andere

14. Zie tabel C.3 in bijlage $C$ voor de gemiddelde indicatie. Zie hoofdstuk 1 voor uitleg over de indicate van het diplomabezit. 
vervolgopleidingen dan in het brood en banket. De redenen hiervoor zijn onduidelijk ${ }^{15}$.

Tabel 2.4

Vervolgopleidingen buiten het leerlingwezen

\begin{tabular}{lr}
\hline & $\%$ \\
\hline Opleidingsrichting & 21 \\
MBO Brood- en banketbakken & 10 \\
MBO-kort Brood- en banketbakken & 10 \\
KMBO orient. schakel & 10 \\
MBO-kort Gastheer en gastvrouw & 8 \\
MTO brood banket & 8 \\
MBO VZ Activiteitenbegeleiding & 5 \\
KMBO CT Brood en banket & 5 \\
MBO-kort Horeca & 23 \\
Overige opleidingen & 100 \\
Totaal &
\end{tabular}

Bron: ROA

Opmerking: De ondergrens voor het opnemen van een opleiding in deze tabel is op $5 \%$ gesteld. Onder de overige opleidingen komen geen brood- en banketopleidingen voor.

Vervolgopleiding en beroep in het leerlingwezen

Alle opleidingen in het leerlingwezen voor het brood- en banketbakkersbedrijf worden gecoördineerd door het landelijk orgaan Stichting Opleidingen Brood en Banket (SOBB). Tabel 2.5 laat de opleidingen in het leerlingwezen zien die gevolgd worden door schoolverlaters van een dagopleiding voor het banketbakkersbedrijf (tabel 2.1). Het blijkt dat onder deze schoolverlaters de opleiding Primair Brood-en banketbakken de meest voorkomende vervolgopleiding is. De SOBB neemt meer dan viervijfde van de leerlingplaatsen van schoolverlaters met een brood- en banketbakkersopleiding voor zijn rekening. Bijna eenvijfde van de schoolverlaters van een brood- en banketbakkersopleiding vindt een leerlingplaats in een andere opleidingsrichting dan behorende tot het brood- en banketbakkersbedrijf. Onverklaarbaar en waarschijnlijk toevallig is het grote aandeel van schoolverlaters met een brood- en banketbakkersopleiding dat een leerlingplaats als Aspirant scheepsmetaalbewerker krijgt.

Een gedeelte (ongeveer 15\%) van de leerlingplaatsen voor het brood- en banketbakkersbedrijf wordt bezet door schoolverlaters die niet een regulier bekostigde vooropleiding tot brood- en bakketbakker (tabel 2.1) hebben.

15. Een mogelijke reden is bijvoorbeeld dat schoolverlaters met een opleiding brood en banket geen baan kunnen vinden in het brood- en banketbedrijf en ook niet verwachten dat ze met een MBO-niveau in dezelfde opleidingsrichting een baan zullen vinden in het brood- en banketbedrijf (zie hoofdstuk 4 voor de arbeidsmarktperspectieven in het brood- en banketbedrijf). Om deze reden zouden ze voor een vervolgopleiding in een andere richting met betere arbeidsmarktperspectieven kunnen kiezen. 
Tabel 2.5

Vervolgopleidingen binnen het leerlingwezen van schoolverlaters met een opleiding voor het banketbakkersbedrijf

\begin{tabular}{lc}
\hline Opleidingsrichting & $\%$ \\
\hline Prim. Brood- en banketbakken & 57 \\
Prim. Tweede Banketbakkersbediende & 7 \\
Prim. Asp. Scheepsmetaalbewerker & 6 \\
Overige Prim. SOBB & 7 \\
Overige Sec. SOBB & 13 \\
Overige opleidingen & 100 \\
Totaal & \\
\hline Bron: ROA & \\
Opmerking: De ondergrens voor het opnemen van een opleiding in deze tabel is op 5\% gesteld. \\
Onder de overige opleidingen komen geen brood- en banketopleidingen voor.
\end{tabular}

\section{Betaald werk buiten het leerlingwezen}

Een opmerkelijk resultaat betreft de schoolverlaters die na het volgen van een vooropleiding tot brood- en banketbakker (tabel 2.1) een betaalde baan krijgen buiten het leerlingwezen. Geen van deze schoolverlaters (dus afgezien van de leerlingplaatsen) blijkt te werken in het beroep van Bakker ambachtelijk (SBC 47105, 47107, 47114) dat binnen het banketbakkersbedrijf valt. Ongeveer een kwart van deze schoolverlaters vindt werk als winkelbediende of als straatverkoper ${ }^{16}$. Dit impliceert tevens dat de schoolverlaters die in de branche van het banketbakkersbedrijf werken geen opleiding tot brood- en banketbakker hebben. De branche van het banketbakkersbedrijf omvat drie bedrijfsklassen van zowel fabrieken en bakkerijen als detailhandel. Het overgrote deel van de schoolverlaters in de banketbakkersbranche komt terecht in de Detailhandel in brood en banket (SBI 5224.1). De opleidingsachtergrond van de schoolverlaters die in de banketbakkersbranche werken is heel divers. Dit blijkt uit tabel $2.6^{17}$. Deze tabel laat zien dat ongeveer de helft van de schoolverlaters werkzaam in de branche voor het banketbakkersbedrijf een economisch-administratieve opleidingsachtergrond heeft. Dit is enigzins begrijpelijk omdat viervijfde van de schoolverlaters in de banketbakkersbranche als winkelbediende of verkoper werkt.

16. Geen enkele schoolverlater uit de schoolverlatersenquête met een vooropleiding tot brood- en banketbakker (tabel 2.1) komt terecht in één van de bedrijfsklassen van het banketbakkersbedrijf (SBI 1581, 1582 of 5224.1). Er blijken overigens ook nauwelijks schoolverlaters met een bakkersopleiding te werken in verwante bakkersberoepen, bijv. als niet-ambachtelijk bakker.

17. In deze tabel zijn ook schoolverlaters zonder diploma weergegeven, omdat het diplomabezit geen vereiste blijkt te zijn om in de branche van het banketbakkersbedrijf (met name de detailhandel) te werken. De resultaten veranderen niet wezenlijk als alleen de gegevens van gediplomeerden worden weergegeven. 
Tabel 2.6

Opleidingsachtergrond van werkende schoolverlaters (excl. leerlingwezen) in de banketbakkersbranche (SBI 1581, 1582, 5224.1)

\begin{tabular}{lc}
\hline Opleidingsrichting & $\%$ \\
\hline MEAO commercieel & 13 \\
MEAO & 11 \\
VBO Verzorging & 10 \\
VBO Mode en kleding & 8 \\
HAVO & 8 \\
MMO detailhandel (MMO-BD) & 7 \\
MBO-kort Bedrijfsadministratie & 6 \\
MBO-kort Handel & 5 \\
MBO-kort Detailhandel & 5 \\
Overige opleidingen & 27 \\
Totaal & 100 \\
\hline
\end{tabular}

\section{Bron: ROA}

Opmerking: De ondergrens voor het opnemen van een opleiding in deze tabel is op $5 \%$ gesteld.

\section{Aansluiting tussen opleiding en beroep}

De aansluiting tussen opleiding en beroep van schoolverlaters werkzaam in de bakkersbranche wordt weergegeven in tabel 2.7. Uit tabel 2.6 is gebleken dat deze werkende schoolverlaters geen bakkersopleiding, maar een overwegend een economisch-administratieve opleiding als achtergrond hebben. De vraag is nu wat de waarde van een dergelijke opleiding is vanuit het perspectief van (gediplomeerde) schoolverlaters werkzaam in de bakkersbranche. Tabel 2.7 laat zien dat een grote meerderheid van werkende schoolverlaters in de bakkersbranche het vereiste opleidingsniveau in hun beroep als lager beoordeelt dan het niveau van de gevolgde opleiding. Voorts geeft meer dan de helft van de werkende schoolverlaters te kennen dat de aansluiting tussen

Tabel 2.7

Aansluiting tussen opleiding en beroep van werkende schoolverlaters in de banketbakkersbranche

\begin{tabular}{|c|c|c|c|}
\hline Variable & $\begin{array}{c}\text { Benutting } \\
\%\end{array}$ & $\begin{array}{c}\text { Aansluiting } \\
\%\end{array}$ & $\begin{array}{c}\text { Vakrichting } \\
\%\end{array}$ \\
\hline $\begin{array}{l}\text { vereist niveau: } \\
\text { lager } \\
\text { hetzelfde }\end{array}$ & $\begin{array}{l}70 \\
30\end{array}$ & & \\
\hline $\begin{array}{l}\text { aansluiting: } \\
\text { matig/slecht } \\
\text { goed/voldoende }\end{array}$ & & $\begin{array}{l}56 \\
44\end{array}$ & \\
\hline $\begin{array}{l}\text { vakrichting vereist: } \\
\text { ja, dezelfde } \\
\text { ja, een andere } \\
\text { nee }\end{array}$ & & & $\begin{array}{r}2 \\
1 \\
97\end{array}$ \\
\hline
\end{tabular}

Bron: ROA

Opm.: Zie hoofdstuk 1 voor uitleg van de termen aansluiting en benutting. 
beroep en opleiding matig of slecht is. Het gegeven dat bij bijna alle werkende schoolverlaters geen specifieke vakrichting vereist werd voor de uitoefening van hun beroep (veelal winkelbediende), kan de matige tot slechte aansluiting verklaren. Dezelfde indicatoren als in tabel 2.7 worden in tabel C.2 (zie bijlage C) weergegeven voor alle werkende schoolverlaters in de schoolverlatersenquête. De aansluiting tussen opleiding en beroep in de bakkersbranche is eveneens matig tot slecht als deze wordt vergeleken met de aansluiting in alle branches waarin werkende schoolverlaters terecht komen.

\section{Borduurbedrijf}

Er is geen regulier bekostigde opleiding tot borduurster. Zowel de bedrijfsklasse als het beroep van het borduurbedrijf komen overeen met die van het modisterijbedrijf en het paramentenvervaardigingsbedrijf. Er blijken echter geen schoolverlaters in de enquête werk te vinden in deze combinatie van bedrijfsklasse en beroep. Het beperkte aantal schoolverlaters dat is gaan werken in de bedrijfsklasse waartoe het borduurbedrijf behoort (SBI 1824, Vervaardiging van overige kleding en toehoren n.e.g.) heeft de vooropleiding MTO mode en kleding. Schoolverlaters met deze opleidingsrichting komen relatief vaak terecht in bedrijfsklassen die betrekking hebben op de detail- en groothandel kleding (ongeveer 50\%) en de vervaardiging van kleding (ongeveer 25\%). Het dominante beroep dat uitgeoefend wordt door schoolverlaters in de bedrijfsklasse waartoe het borduurbedrijf behoort is het beroep van Modelnaaister en patroonmaker kleding. Buiten deze bedrijfsklasse komt dit beroep onder schoolverlaters nauwelijks voor.

\section{Breibedrijf}

$\mathrm{Er}$ is geen regulier bekostigde opleiding voor het breibedrijf. Ook zijn er geen schoolverlaters uit de enquête die in het breibedrijf zijn gaan werken. De branchevereniging voor het breibedrijf vertegenwoordigt de breiers die textielgoederen vervaardigen met behulp van handbreimachnines. Er is echter geen beroep bekend waarin breiers van handbreimachines werken. Het beroep van Breier tricot, kleding dat in de Standaard Beroepenclassificatie genoemd wordt is geen ambacht, omdat het valt onder de machinebediendes in de industrie (SBC 27109).

\section{Consumptie-ijsbereidingsbedrijf}

Er is geen regulier bekostigde opleiding voor het consumptie-ijsbereidingsbedrijf ${ }^{18}$. Het consumptie-ijsbereidingsbedrijf valt onder twee bedrijfsklassen, namelijk Bereiding van consumptie-ijs (SBI 1552) en IJssalons (SBI 5530.3). Voor deze bedrijfsklassen geldt dat er een grote diversiteit van opleidingsrichtingen is onder de schoolverlaters die in

18. Binnen de opleidingen tot brood- en banketbakker (zie paragraaf 2.1) bestaat wel een keuzevak voor ijsbereiding. 
het consumptie-ijsbereidingsbedrijf werken (zie het voorbeeld in tabel 1.1 in hoofdstuk 1).

\section{Dakdekkersbedrijf}

$\mathrm{Er}$ is geen regulier bekostigde voltijds dagopleiding voor het dakdekkersbedrijf. Er bestaan diverse opleidingen tot dak-, lei- of pannendekker en dakbedekkingsmonteur in het primaire en secundaire leerlingwezen. Er zijn te weinig schoolverlaters in de schoolverlatersenquête die een leerlingplaats in het dakkerdekkersbedrijf hebben om conclusies te trekken over hun vooropleiding en het beroep en de branche waarin ze werken. Dit heeft mogelijk te maken met de officieel vastgestelde leeftijdsgrens van minimaal 18 jaar om te werken in het dakdekkersbedrijf. Veel schoolverlaters van het VBO zijn derhalve te jong om meteen in het dakdekkersbedrijf te gaan werken.

\section{Fietsherstellersbedrijf}

Het fietsherstellersbedrijf valt gedeeltelijk onder dezelfde bedrijfsklasse (SBI 5274) als andere reparatiebedrijven ten behoeve van particulieren. Dit is een bedrijfsklasse waartoe ook andere brancheverenigingen van het HBA behoren ( $n$.I. het kledingreparatiebedrijf, het muziekinstrumentenmakersbedrijf, het naaimachinebedrijf, het tapijtherstellingsbedrijf en het zakkenstopbedrijf). Er zijn weinig schoolverlaters die in deze bedrijfsklasse gaan werken.

De bedrijfsklasse Detailhandel in fietsen (SBI 5248.5) behoort daarentegen uitsluitend tot het fietsherstellersbedrijf. In deze bedrijfsklasse werken schoolverlaters met een diverse opleidingsachtergrond. Een deel van de schoolverlaters dat in deze bedrijfsklasse werkt, volgt een opleiding in het leerlingwezen (namelijk Monteur Tweewielers). Er is geen regulier bekostigde voltijds dagopleiding voor het fietsherstellersbedrijf. Voorts is het beroep Rijwiel-, motorrijwiel-, bromfietshersteller, hulpautomonteur het belangrijkste beroep in deze bedrijfsklasse. Dit beroep wordt overigens met name uitgeoefend in de bedrijfsklasse van de Handel in en reparatie van personenauto's (SBI 5010.4).

\section{Fijn-keramischbedrijf}

Er is een VBO-opleiding voor keramische techniek. Daarnaast zijn er opleidingen in het leerlingwezen voor (fijn)keramische technieken. De schoolverlaters die in het fijnkeramischbedrijf werken, hebben echter een diverse opleidingsachtergrond.

\section{Glasbewerkingsbedrijf}

$\mathrm{Er}$ is geen regulier bekostigde voltijds dagopleiding voor het glaswerkingsbedrijf. Binnen het leerlingwezen bestaat er de opleiding Primair Glasbewerken. Er zijn geen schoolverlaters bekend uit de regulier bekostigde opleidingen die in de opleiding Primair 
Glasbewerken zijn ingestroomd. Er zijn slechts enkele schoolverlaters uit de enquête die in de branche of het beroep van glasbewerking zijn gaan werken. Onder deze schoolverlaters is geen dominante opleidingsrichting voor het glasbewerkingsbedrijf.

\section{Glazeniersbedrijf}

Er is geen regulier bekostigde voltijds dagopleiding tot glaszetter. Binnen het leerlingwezen bestaan de opleidingen Primair en Voortgezet Glaszetter. Er zijn geen schoolverlaters uit de enquête die de opleidingen tot glaszetter binnen het leerlingwezen zijn gaan volgen.

\section{Glazenwassers- en schoonmaakbedrijf}

$\mathrm{Er}$ is geen regulier bekostigde opleiding tot glazenwasser. De branche voor glazenwassers is gedefinieerd door de bedrijfsklasse Reiniging van gebouwen (SBI 7470.1). Meer dan viervijfde deel van de werknemers in deze bedrijfsklasse werken in het beroep van glassenwasser of schoonmaker van interieurs, keukens en ramen (SBC $11133)^{19}$. De overige werkenden hebben het beroep van schoonmaker van ketels, tanks en metalen voorwerpen (SBC 11111; zie ook het schoorsteenvegersbedrijf), secretaresse of bedrijfshoofd. Het totale aantal schoolverlaters in Nederland dat in de glazenwassers- en schoonmaakbranche in Nederland gaat werken wordt op ongeveer 550 per jaar geschat. Uit tabel 2.8 blijkt dat de opleidingsachtergrond van de schoolverlaters die als glazenwasser of schoonmaker werken heel divers is. Daarnaast is een relatief groot aandeel van schoolverlaters die als glazenwasser of schoonmaker werken afkomstig van meer algemene opleidingen als HAVO en KMBO Oriënterende schakel.

Tabel 2.8

Opleidingsachtergrond van werkenden in het glazenwassers- en schoonmaakbedrijf

\begin{tabular}{lc}
\hline Opleidingsrichting & $\%$ \\
\hline HAVO & 18 \\
KMBO Oriënterende schakel & 10 \\
VBO Verzorging & 9 \\
MBO-kort Administratief & 5 \\
MBO-kort Secretariaat & 5 \\
VBO Uiterlijke verzorging & 5 \\
MDGO CCD & 5 \\
Overige opleidingen & 43 \\
Totaal & 100 \\
\hline
\end{tabular}

Bron: ROA

Opm.: De opleiding MDGO CCD staat voor de lange opleiding facilitaire dienstverlening van civiele en consumptief-technische diensten.

19. De glazenwassers zijn echter in de CBS-classificatie niet te onderscheiden van de schoonmakers (zie ook paragraaf 3.10). Het schoonmakersbedrijf is echter niet aangesloten bij het HBA. 
Tabel 2.9

Diplomabezit van schoolverlaters in het glazenwassersbedrijf

Opleidingsrichting Indicator

met diploma of (deel-)certificaat

Bron: ROA

Uit tabel 2.9 blijkt bovendien dat het diplomabezit van schoolverlaters die als glazenwasser of schoonmaker werken relatief laag is ten opzichte van de totale steekproef van schoolverlaters (bijlage $\mathrm{C}$ ).

\section{Aansluiting tussen opleiding en beroep}

Tabel 2.10 geeft de aansluiting tussen opleiding en beroep weer van werkende schoolverlaters in het glazenwassers- en schoonmaakbedrijf. Uit de tabel blijkt dat bijna alle schoolverlaters, namelijk $94 \%$, vinden dat ze onder hun niveau werken. Dit percentage is veel hoger dan het gemiddelde voor alle werkende schoolverlaters in tabel C.2 (zie bijlage $\mathrm{C}$ ). Hetzelfde geldt voor de matig tot slechte aansluiting en de vereiste vakrichting. De aansluiting in het glazenwassers- en schoonmaakbedrijf lijkt in beginsel heel slecht te zijn. Niettemin kan er geconcludeerd worden dat de aansluiting tussen opleiding en beroep in het glazenwassers- en schoonmaakbedrijf meevalt omdat er ook geen eisen worden gesteld aan die aansluiting. Een algemene opleiding voor het glazenwassers- en schoonmaakbedrijf is blijkbaar voldoende, aangezien bijna alle werkende schoolverlaters in het glazenwassers- en schoonmaakbedrijf vinden dat ze onder hun opleidingsniveau werken.

Tabel 2.10

Aansluiting tussen opleiding en beroep van werkende schoolverlaters in het glazenwassers- en schoonmaakbedrijf

\begin{tabular}{|c|c|c|c|}
\hline Variable & $\begin{array}{c}\text { Benutting } \\
\%\end{array}$ & $\begin{array}{c}\text { Aansluiting } \\
\%\end{array}$ & $\begin{array}{l}\text { Vakrichting } \\
\%\end{array}$ \\
\hline vereist niveau: & & & \\
\hline $\begin{array}{l}\text { lager } \\
\text { hetzelfde }\end{array}$ & $\begin{array}{r}94 \\
6\end{array}$ & & \\
\hline $\begin{array}{l}\text { aansluiting: } \\
\text { matig/slecht } \\
\text { goed/voldoende }\end{array}$ & & $\begin{array}{l}52 \\
48\end{array}$ & \\
\hline $\begin{array}{l}\text { vakrichting vereist: } \\
\text { ja, dezelfde } \\
\text { ja, een andere } \\
\text { nee }\end{array}$ & & & $\begin{array}{r}0 \\
0 \\
100\end{array}$ \\
\hline
\end{tabular}

Bron: ROA

Opm.: Zie hoofdstuk 1 voor uitleg van de termen aansluiting en benutting. 


\section{Goud- en zilversmidbedrijf}

Er zijn diverse regulier bekostigde voltijds dagopleidingen tot goud- en zilversmid (incl. edelsmid) in het MBO-kort, MTO en MBO. Binnen het leerlingwezen bestaan de opleidingen Primair Goud- en Zilversmid en Voortgezet Goudsmid. Er zijn geen schoolverlaters van de opleidingen tot goud- en zilversmid in de enquête.

\section{Grimeursbedrijf}

Er is geen regulier bekostigde opleiding tot grimeur. Bovendien vallen het beroep en de bedrijfsklasse waarin grimeurs werkzaam zijn gedeeltelijk samen met het beroep en de bedrijfsklasse van zowel de schoonheidsverzorgers als de toneelkappers. In de bedrijfsklasse Schoonheidsverzorging, voetverzorgers en manicures (SBI 9302.2) zijn overwegend schoolverlaters werkzaam met een MBO VZ Uiterlijke verzorging, MBO VZ Schoonheidsverzorging en MDGO Uiterlijke Verzorging. Omdat deze opleidingsrichtingen ook opleiden tot schoonheidsspecialist zijn de grimeurs wat betreft hun opleidingsachtergrond en de uitoefening van hun vak niet te onderscheiden van de schoonheidsspecialisten (zie voor verdere informatie het schoonheids-verzorgingsbedrijf). In de bedrijfsklasse Dienstverlening t.b.v. kunstbeoefening en organisatie van culturele evenementen (SBI 9302.2) waarin volgens bijlage A grimeurs werkzaam zouden moeten zijn, vinden voornamelijk schoolverlaters met een technische of economische achtergrond werk.

\section{Kappersbedrijf}

\section{Vooropleidingen}

Formeel zijn de belangrijkste vooropleidingen voor de kappersbranche MBO-kort Haarverzorging, MBO Haarverzorging en MDGO UV (uv/hv). Tabel $2.11 \mathrm{geeft}$ de verdeling van gediplomeerde schoolverlaters ${ }^{20}$ onder deze opleidingen aan. Het aantal gediplomeerde schoolverlaters van de hier genoemde kappersopleidingen wordt op ongeveer 300 per jaar geschat. Tabel 2.12 presenteert de indicator voor het diplomabezit van de schoolverlaters van deze opleidingen. De eerstgenoemde opleiding heeft het grootste aandeel onder de gediplomeerde schoolverlaters met een kappersopleiding, terwijl de laatstgenoemde opleiding duidelijk het hoogste diplomabezit heeft onder alle schoolverlaters met een kappersopleiding. Het diplomabezit van de twee MBO-opleidingen is relatief laag (zie bijlage $\mathrm{C}$ ).

20. Omdat er vastgestelde opleidingen voor het kappersbedrijf lijken te zijn, worden alleen gegevens van gediplomeerde schoolverlaters met een kappersopleiding gepresenteerd (tenzij anders vermeld). 
Tabel 2.11

Vooropleidingen voor het kappersbedrijf

\begin{tabular}{lr}
\hline Opleidingsrichting & $\%$ \\
\hline MBO-kort Haarverzorging & 62 \\
MBO VZ Haarverzorging & 19 \\
MDGO UV (uv/hv) & 19 \\
Totaal & 100 \\
\hline
\end{tabular}

Bron: ROA

Tabel 2.12

Diplomabezit van schoolverlaters met een opleiding voor het kappersbedrijf

\begin{tabular}{lc}
\hline Opleidingsrichting & Indicator \\
\hline MBO-kort Haarverzorging & 7 \\
MBO VZ Haarverzorging & 7 \\
MDGO UV (uv/hv) & 10 \\
\hline
\end{tabular}

Bron: ROA

\section{Bestemming van schoolverlaters}

De bestemming van (gediplomeerde) schoolverlaters uit het kappersbedrijf wordt weergegeven in tabel 2.13. Ten opzichte van het totale aantal schoolverlaters (zie bijlage C), krijgt een relatief groot percentage schoolverlaters van kappersopleidingen betaald werk of een leerlingplaats, terwijl een relatief klein percentage verder studeert in een andere vervolgopleiding.

Tabel 2.13

Bestemming van schoolverlaters met een opleiding voor het kappersbedrijf

\begin{tabular}{lrrrrr}
\hline Opleidingsrichting & $\begin{array}{r}\text { Scholier/ } \\
\text { student } \\
\%\end{array}$ & $\begin{array}{r}\text { Betaald } \\
\text { werk } \\
\%\end{array}$ & LLW & Werkloos & Anders \\
\hline & 41 & 31 & 14 & 4 \\
\hline $\begin{array}{l}\text { Gemiddelde (gewogen) } \\
\text { over opleidingen }\end{array}$ & 10 & 41 & & & \\
\hline
\end{tabular}

Bron: ROA

Vervolgopleidingen buiten het leerlingwezen

Er is geen dominante opleidingsrichting onder het beperkte aantal schoolverlaters met een kappersopleiding dat een vervolgopleiding gaat doen. 
Vervolgopleiding en beroep in het leerlingwezen

Binnen het leerlingwezen voor de kappersbranche zijn er de primaire opleidingen Dameskapper, Herenkapper en Dames/herenkapper en de secundaire opleidingen Dameskapper en Herenkapper. Schoolverlaters met een vooropleiding MBO VZ Haarverzorging blijken niet of nauwelijks in het leerlingwezen te gaan werken, terwijl schoolverlaters met een opleiding MBO-kort Haarverzorging vooral een secundaire opleiding in het leerlingwezen gaan volgen. Voorts blijkt dat meer dan viervijfde van de schoolverlaters in het leerlingwezen van de kappersbranche een andere vooropleiding heeft dan een kappersopleiding. Met name de vooropleidingen VBO Uiterlijke Verzorging, VBO Verzorging, MAVO en in mindere mate MBO-kort Haarverzorging komen veel voor onder de leerlingen in de kappersbranche. Ongeveer eenvijfde van de leerlingen in de kappersbranche oefent het beroep van kapper (SBC 57212) uit, de rest van deze leerlingen oefent het beroep van kappershulp (SBC 37210) uit.

Betaald werk buiten het leerlingwezen

In de kapperbranche (SBI 9302.1) zijn kappers (SBC 57212) en kappershulpen (SBC 37210 ) te onderscheiden ${ }^{21}$. Schoolverlaters kunnen na het afsluiten van hun opleiding in beide beroepen gaan werken. Viervijfde van de schoolverlaters met een kappersopleiding met betaald werk (buiten het leerlingwezen) vindt werk in een kappersberoep.

Tabel 2.14

Opleidingsachtergrond van werkenden (excl. leerlingwezen) in het kappersbedrijf

\begin{tabular}{lc}
\hline Opleidingsrichting & $\%$ \\
\hline MBO VZ Uiterlijke verzorging & 18 \\
MAVO & 17 \\
MDGO UV (UVIVDH) & 14 \\
MBO-kort Haarverzorging & 12 \\
MBO VZ Haarverzorging & 9 \\
MDGO UV (UV/HV) & 9 \\
MDGO UV & 8 \\
MBO-kort Uiterlijke verzorging & 6 \\
VBO Verzorging & 6 \\
Totaal & 100 \\
\end{tabular}

Bron: ROA

Een klein deel van deze schoolverlaters werkt als kappershulp, maar het merendeel werkt als kapper. Uit tabel 2.14 blijkt echter dat een groot deel van de schoolverlaters die in een betaalde baan buiten het leerlingwezen als kapper werken, geen kappersopleiding heeft. De meest voorkomende opleidingen van werkenden in de kapper-

21. Het kleine aantal schoolverlaters dat in een ander beroep dan kapper(shulp), bijv. secretaresse, in de kappersbranche gaat werken, wordt uitgesloten in de verdere analyse. 
branche zijn de opleidingen MBO VZ Uiterlijke verzorging, MAVO en MDGO UV ( $u v / v d h)$, gevolgd door de drie kappersopleidingen die eerder genoemd zijn. Deze kappersopleidingen nemen slechts $30 \%$ van het totale aantal opleidingen van werkende schoolverlaters in de kappersbranche voor hun rekening.

\section{Aansluiting tussen opleiding en beroep}

Tabel 2.15 presenteert de indicatoren betreffende de aansluiting tussen opleiding en beroep in het kappersbedrijf. Voor $10 \%$ van de werkende schoolverlaters is het vereiste opleidingsniveau in het kappersbedrijf hoger dan hun feitelijke opleidingsniveau. Dit is hoger dan het gemiddelde voor alle schoolverlaters in tabel C.2 (zie bijlage C). Voorts beoordeelt $82 \%$ van de werkende schoolverlaters in het kappersbedrijf de aansluiting tussen opleiding en beroep als goed of voldoende, hetgeen veel hoger dan het gemiddelde in tabel C.2. Voor ongeveer tweederde van de werkende schoolverlaters in het kappersbedrijf is de opleidingsachtergrond vereist voor de uitoefening van het beroep, hetgeen ook veel hoger is dan het gemiddelde in tabel C.2.

\section{Kledingreparatiebedrijf}

Er zijn geen opleidingen voor het kledingreparatiebedrijf. Er zijn geen schoolverlaters uit de enquête die in het kledingreparatiebedrijf zijn gaan werken. Het kledingreparatiebedrijf valt onder dezelfde branche (SBI 5274) als andere reparatiebedrijven ten behoeve van particulieren (n.l. het fietsherstellersbedrijf, het muziekinstrumentenmakersbedrijf, het naaimachinebedrijf, het tapijtherstellingsbedrijf en het zakkenstopbedrijf).

Tabel 2.15

Aansluiting tussen opleiding en beroep van werkende schoolverlaters in het kappersbedrijf

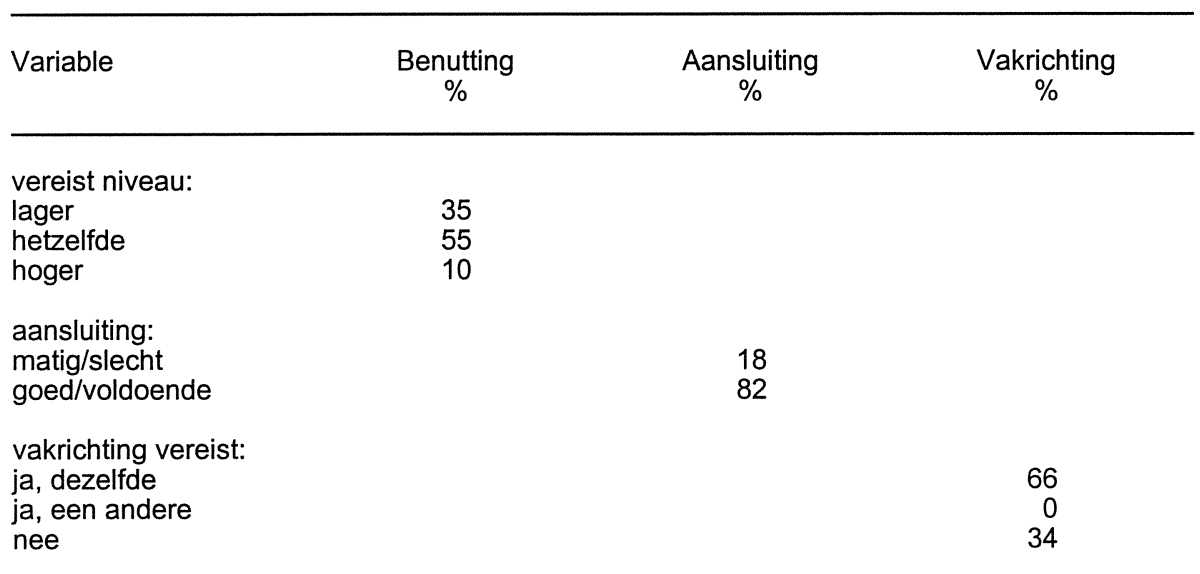

Bron: ROA

Opm.: Zie hoofdstuk 1 voor uitleg van de termen aansluiting en benutting. 


\section{Korsettenvervaardigingsbedrijf}

$\mathrm{Er}$ is geen regulier bekostigde opleiding voor het korsettenvervaardigingsbedrijf. De bedrijfsklasse waartoe het korsettenvervaardigingsbedrijf behoort (SBI 1823), valt gedeeltelijk samen met de bedrijfsklasse van het maatoverhemdenbedrijf. De functies die horen bij het korsettenvervaardigingsbedrijf, te weten Korsettencoupeur confectie, Korsettennaaister confectie en Korsettenstikster confectie, vallen onder beroepen die ook in andere branches voorkomen. Er zijn geen schoolverlaters waargenomen die in het korsettenvervaardigingsbedrijf zijn gaan werken.

\section{Lederwarenambacht}

Er zijn twee regulier bekostigde voltijds dagopleidingen voor het lederwarenambacht, n.I. LTO Overige leerbewerking en KMBO Textiel en leder. Bovendien is er een primaire opleiding Vervaardiger van Lederwaren. De bedrijfsklassen waartoe het lederwarenambacht behoort vallen gedeeltelijk samen met de bedrijfsklasse van het zadelmakersbedrijf (SBI 1920, Vervaardiging van lederwaren, excl. kleding en schoeisel) en de bedrijfsklasse van het schoenherstellersbedrijf (SBI 5271, Reparatie van schoeisel en lederwaren). Ook de beroepen die in deze branches worden uitgeoefend vallen grotendeels samen met de beroepen van het lederwarenambacht. Er zijn geen schoolverlaters in de enquête die in het lederwarenambacht zijn gaan werken.

\section{Maatoverhemdenbedrijf}

De opleidingen tot maatkleermaker zijn onder andere gericht op het maatoverhemdenbedrijf. Er zijn diverse regulier bekostigde voltijdsdagopleidingen in het LTO (Kleermaker), MBO-kort (Vakman Maatkleding) en MBO Mode en Kleding (Breed-vakman of Ondernemer maatkledingbedrij). Bovendien zijn er diverse opleidingen in het leerlingwezen tot kleermaker (bijv. Maatkleermaker kleinvak en grootvak, Meester dames- of herenkleermaker) op primair, secundair en tertiair niveau. Er zijn echter te weinig schoolverlaters van deze opleidingen in de schoolverlatersenquête om conclusies te trekken over deze groep. De bedrijfsklasse waartoe het maatoverhemdenbedrijf behoort valt gedeeltelijk samen met het korsettenvervaardigingsbedrijf, terwijl de beroepen die bij het maatoverhemdenbedrijf horen gedeeltelijk samenvallen met het rolluiken- en markiezenmakersbedrijf.

\section{Modisterijbedrijf}

Er is geen regulier bekostigde opleiding tot modist hoeden en petten. Zowel de bedrijfsklasse als het beroep van het modisterijbedrijf komen overeen met die van het borduurbedrijf en het paramentenvervaardigingsbedrijf. Er blijken echter geen schoolverlaters uit de schoolverlatersenquête werk te vinden in deze combinatie van bedrijfsklasse en beroep. Het beperkte aantal schoolverlaters dat is gaan werken in de bedrijfs- 
klasse waartoe het modisterijbedrijf (SBI 1824, Vervaardiging van overige kleding en toehoren n.e.g.) behoort heeft de vooropleiding MTO mode en kleding. Schoolverlaters met deze opleidingsrichting komen relatief vaak terecht in bedrijfsklassen die betrekking hebben op de detail- en groothandel kleding (ongeveer $50 \%$ ) en de vervaardiging van kleding (ongeveer 25\%). Het dominante beroep dat uitgeoefend wordt door schoolverlaters in de bedrijfsklasse waartoe het modisterijbedrijf behoort is het beroep van Modelnaaister en patroonmaker kleding. Buiten deze bedrijfsklasse komt dit beroep nauwelijks voor.

\section{Muziekinstrumentmakersbedrijf}

Er is geen opleiding tot muziekinstrumentmaker ${ }^{22}$. De branche van het muziekinstrumentmakersbedrijf is op te splitsen in drie bedrijfsklassen, namelijk Reparatie ten behoeve van particulieren n.e.g. (SBI 5274, onder deze bedrijfsklasse valt ook de reparatie van andere gebruiksartikelen zoals kleding en naaimachines), Vervaardiging van muziekinstrumenten (SBI 3630) en Detailhandel in muziekinstrumenten (SBI 5245.7). Er is een apart beroep voor muziekinstrumentmakers in de Standaard Beroepenclassificatie. Er zijn te weinig schoolverlaters in de schoolverlatersenquête die in het muziekinstrumentmakersbedrijf zijn gaan werken om hierover een representatief beeld te kunnen geven.

\section{Naaimachinebedrijf}

Er is geen regulier bekostigde opleiding voor het naaimachinebedrijf. De branche van het naaimachinebedrijf maakt deel uit van twee bedrijfsklassen, namelijk Reparatie ten behoeve van particulieren (SBI 5274) en Detailhandel in naai- en breimachines (SBI5245.8). Het beroep van onderhoudsmonteur kantoor- en huishoudnaaimachines valt samen met het beroep van onderhoudsmonteur van motoren en andere machines. Er zijn geen schoolverlaters in de schoolverlatersenquête die in het naaimachinebedrijf zijn gaan werken.

\section{Optiekbedrijf}

Voor het optiekbedrijf is er een korte opleiding $M B O$ assistent optiek en en een lange opleiding MBO optiek ${ }^{23}$. Voorts worden er opleidingen in het leerlingwezen aangeboden, namelijk de primaire opleiding Assistent-Opticien en Vakkracht in het opticiensbedrijf. Er zijn geen schoolverlaters van deze opleidingen in de enquête waargenomen. Ook zijn er geen schoolverlaters in de enquête die in één van de bedrijfsklassen van het optiekbedrijf (SBI 3340 Vervaardiging van optische instrumenten, foto- en film-

22. Er is wel een vestigingsdiploma Muziekinstrumenten kleinhandel.

23. Sinds kort worden er ook opleidingen op HBO-niveau (HBO Optometrist) voor het optiekbedrijf aangeboden. 
apparatuur, en SBI 5248.2 Detailhandel in optische artikelen) zijn gaan werken. Het beroep van opticien valt bovendien samen met andere beroepen in een beroepsklasse.

\section{Orthopedisch schoentechnisch bedrijf}

$\mathrm{Er}$ is geen regulier bekostigde voltijds dagopleiding tot orthopedisch schoentechnicus. Binnen het leerlingwezen bestaan de opleidingen Aspirant orthopedisch schoentechnicus (primair), Assistent orthopedisch schoentechnicus (secundair) en Orthopedisch schoentechnicus (tertiair). De beroepen die horen bij het orthopedisch schoentechnisch bedrijf zijn Orthopedisch schoenmaker (-technicus) en Orthopedisch maatnemer en modelmaker. De branche van het orthopedisch schoentechnisch bedrijf valt onder de (bredere) bedrijfsklasse Vervaardiging van medische apparaten en instrumenten en overige orthopedische en prothese-artikelen. In deze bedrijfsklasse werken overigens schoolverlaters met een hele diverse opleidingsachtergrond (van economische, technische en dienstverlenende middelbare opleidingen).

\section{Paramentenvervaardigingsbedrijf}

Er is geen regulier bekostigde opleiding tot voor het paramentenvervaardigingsbedrijf. Zowel de bedrijfsklasse als het beroep van het paramentenvervaardigingsbedrijf bedrijf komen overeen met die van het borduurbedrijf en het modisterijbedrijf. Er blijken echter geen schoolverlaters werk te vinden in deze combinatie van bedrijfsklasse en beroep. In het paramentenvervaardigingsbedrijf werken sierstikselstiksters, sierstiksters, linnenknippers en -snijders. Het beperkte aantal schoolverlaters dat is gaan werken in de bedrijfsklasse waartoe het paramentenvervaardigingsbedrijf (SBI 1824, Vervaardiging van overige kleding en toehoren n.e.g.) behoort heeft de vooropleiding MTO mode en kleding. Schoolverlaters met deze opleidingsrichting komen relatief vaak terecht in bedrijfsklassen die betrekking hebben op de detail- en groothandel kleding (ongeveer $50 \%$ ) en de vervaardiging van kleding (ongeveer $25 \%$ ). Het dominante beroep dat uitgeoefend wordt door schoolverlaters in de bedrijfsklasse waartoe het paramentenvervaardigingsbedrijf behoort is het beroep van Modelnaaister en patroonmaker kleding. Buiten deze bedrijfsklasse komt dit beroep onder schoolverlaters nauwelijks voor.

\section{Parketvloerleggersbedrijf}

$\mathrm{Er}$ is geen regulier bekostigd voltijds dagopleiding tot parketvloerlegger. In het leerlingwezen is er de primaire opleiding Parketvloerleggen. Er zijn geen schoolverlaters die deze opleiding zijn gaan volgen. De branche voor het parketvloerleggersbedrijf is een deel van de bedrijfsklasse Afwerken van vloeren en wanden (SBI 4543). De schoolverlaters die in deze bedrijfsklasse terecht komen hebben vooral een technische (VBO, $\mathrm{KMBO}$ of $\mathrm{MBO}$ ) achtergrond. Het beroep van parketvloerlegger valt samen met andere beroepen zoals bouwvak- en betontimmerman en monteur systeembouw (SBC 26211). 


\section{Rolluiken en markiezenmakersbedrijf}

Er zijn geen regulier bekostigde opleidingen of opleidingen in het leerlingwezen voor het rolluiken en markiezenmakersbedrijf. Er zijn geen schoolverlaters die in de bedrijfsklasse van het rolluiken en markiezenmakersbedrijf werkzaam zijn (Overige bouwinstallatie, SBI 4534). De beroepen die behoren tot het rolluiken en markiezenmakersbedrijf hebben betrekking op enerzijds bouwvak- en timmerwerkzaamheden en anderzijds confectie- en kleermakerwerkzaamheden.

\section{Schoenherstellersbedrijf}

Er is geen regulier bekostigde voltijds dagopleiding voor het schoenherstellersbedrijf. Er zijn wel diverse opleidingen in het leerlingwezen, waaronder de primaire opleidingen Industrieel Schoenmaken en Schoenherstellersgezel en de secundaire opleiding Kaderfunctionaris Schoenindustrie. Het beroep van schoenmaker valt samen met dat van andere beroepen die betrekkingen hebben op lederwaren, zoals de lederwaren- en zadelmakers. Ook de bedrijfsklasse van het schoenherstellersbedrijf (Reparatie van schoeisel en lederwaren, SBI 5271) valt gedeeltelijk samen met de branche van het lederwarenambacht. Er zijn te weinig schoolverlaters in de enquête werkzaam in het schoenherstellersbedrijf om conclusies te trekken over hun opleidingsachtergrond.

\section{Schoonheidsverzorgingsbedrijf}

\section{Vooropleidingen}

Er zijn regulier bekostigde voltijds dagopleidingen voor het schoonheidsverzorgingsbedrijf, waaronder de opleidingen MDGO UV (uv/os), MDGO UV (uv/osv) en MBO VZ Schoonheidsverzorging ${ }^{24}$. Uit tabel 2.16 is af te lezen dat ongeveer de helft van de gediplomeerde schoolverlaters van deze opleidingen van de laatstgenoemde opleiding afkomstig is. Op basis van de steekproef wordt geschat dat er in heel Nederland ongeveer 150 gediplomeerde schoolverlaters per jaar afkomstig zijn van deze opleidingen. Het diplomabezit van deze opleiding is volgens tabel 2.17 lager dan in de twee andere opleidingen voor het schoonheidsverzorgingsbedrijf, waarvoor het diplomabezit relatief hoog is ten opzichte van het totaal van schoolverlaters in de enquête (zie bijlage C).

24. De afkortingen $u v$, os en osv staan voor respectievelijk uiterlijke verzorging, vakbekwaamheid en ondernemersdiploma schoonheidsverzorging en vakbekwaamheid en ondernemer schoonheids- en voetverzorging. Binnen de verzorgende opleidingen van het $M D G O$ en het $M B O$ bestaan er overigens diverse verwante opleidingen voor haarverzorging, schoonheidsverzorging en voetverzorging. Daarnaast spelen particuliere opleidingen een belangrijke rol in het opleidingenstelsel voor de schoonheids- en voetverzorging. 
Tabel 2.16

Vooropleidingen voor het schoonheidsverzorgingsbedrijf

\begin{tabular}{lc}
\hline Opleidingsrichting & $\%$ \\
\hline MBO VZ Schoonheidsverzorging & 48 \\
MDGO UV (uv/osv) & 35 \\
MDGO UV (uv/os) & 18 \\
Totaal & 100 \\
\hline
\end{tabular}

Bron: ROA

Tabel 2.17

Diplomabezit van schoolverlaters met een opleiding voor het schoonheidsverzorgingsbedrijf

\begin{tabular}{lc}
\hline Opleidingsrichting & Indicator \\
\hline MBO VZ Schoonheidsverzorging & 8 \\
MDGO UV (uv/osv) & 10 \\
MDGO UV (uv/os) & 10
\end{tabular}

Bron: ROA

\section{Bestemming van schoolverlaters}

De schoolverlaters die één van de bovengenoemde opleidingen voor het schoonheidsverzorgingsbedrijf hebben gevolgd verrichten, zoals uit tabel 2.18 blijkt,voor meer dan tweederde betaald werk buiten het leerlingwezen, hetgeen relatief heel hoog is (zie bijlage C).

Tabel 2.18

Bestemming van schoolverlaters met een opleiding voor het schoonheidsverzorgingsbedrijf

\begin{tabular}{lrrrrr}
\hline Opleidingsrichting & $\begin{array}{r}\text { Scholier/ } \\
\text { student } \\
\%\end{array}$ & $\begin{array}{r}\text { Betaald } \\
\text { werk } \\
\%\end{array}$ & LLW & Werkloos & Anders \\
\hline $\begin{array}{l}\text { Gemiddelde (gewogen) } \\
\text { over opleidingen }\end{array}$ & 27 & 69 & 2 & 0 & $\%$ \\
\hline
\end{tabular}

Bron: ROA

\section{Vervolgopleidingen buiten het leerlingwezen}

De vervolgopleidingen van schoolverlaters van bovenstaande opleidingen voor het schoonheidsverzorgingsbedrijf zijn voornamelijk opleidingen die een raakvlak met de dienstverlening en gezondheidszorg hebben. Dit kan echter uiteenlopen van HGZO podo-therapie tot Diëtetiek. 
Er zijn geen opleidingen in het leerlingwezen voor het schoonheidsverzorgingsbedrijf. Het beperkte aantal schoolverlaters uit één van bovenstaande opleidingen die een leerlingplaats krijgen, komen dan ook buiten het schoonheidsverzorgingsbedrijf terecht.

\section{Betaald werk buiten het leerlingwezen}

Het schoonheidsverzorgingsbedrijf valt onder de bedrijfsklasse Schoonheidsverzorging, voetverzorgers en manicures (SBI 9302.2). Binnen deze bedriffsklasse is het schoonheidsverzorgingsbedriff te onderscheiden door het beroep als afbakening te gebruiken. Het beroep van de schoonheidsspecialisten in deze bedrijfsklasse is Kapper, pruikenmaker, grimeur, schoonheidsspecialist (SBC 57212). Meer dan de helft van de schoolverlaters werkzaam in het schoonheidsverzorgingsbedrijf heeft één van de bovenstaande opleidingen voor schoonheidsverzorging afgesloten. De andere schoolverlaters die in het schoonheidsverzorgingsbedrijf werkzaam zijn hebben een verwante opleiding, n.I. de opleiding Uiterlijke verzorging van het MBO VZ of het MDGO.

\section{Aansluiting opleiding en beroep}

Er zijn te weinig schoolverlaters uit de steekproef om vergaande conclusies te trekken over de aansluiting tussen opleiding en beroep in het schoonheidsverzorgingsbedrijf. Niettemin kan gesteld worden dat ongeveer viervijfde van de schoolverlaters werkzaam in het schoonheidsverzorgingsbedrijf te kennen geeft dat de aansluiting voldoende of goed is. Eenzelfde deel van deze schoolverlaters geeft aan dat de opleidingsachtergrond overeenkomt met de vereiste vakrichting voor de baan.

\section{Schoorsteenvegersbedrijf}

Er is geen voltijds dagopleiding tot schoorsteenveger. Sinds kort bestaat er een opleiding tot gezel-schoorsteenvege ${ }^{25}$. De branche voor schoorsteenvegers valt onder de combinatie van het beroep van schoonmaker (SBC 11111) en de bedrijfsklasse Reiniging van gebouwen (SBI 7470.1). Onder deze laatste bedrijfsklasse valt ook het glazenwassersbedrijf. Uit het beperkte aantal schoolverlaters dat als schoorsteenveger gaat werken blijkt dat de opleidingsachtergrond van deze schoolverlaters heel verschillend kan zijn.

\section{Slagersbedrijf}

Er zijn diverse regulier bekostigde opleidingen die kunnen voorbereiden op een baan

25. Daarnaast speelt het contractonderwijs in het schoorsteenvegersbedrijf een belangrijke rol. 
in het slagersbedrijf ${ }^{26}$. In het voltijds onderwijs zijn dit onder andere de opleidingen ITO/ LTO CT Vleesbe- en verwerken, VBO CT Vleesbewerken, MMO Slagers- vakschool, $M B O$ Slagerij en vleessector, MBO Leidinggevende in de vleesverwerkende industrie, Ondernemer slagersbedrijf. In het leerlingwezen zijn dit onder andere de primaire opleidingen Leerling slager, Industrieel bewerker pluimvee en vlees en de secundaire opleidingen Industrie en Vleesverwerking resp. Pluimvee, Winkelslager, Chefslager, Worstmaker-specialiteitenslager, Islamitisch winkelslager. Er zijn nauwelijks schoolverlaters van deze regulier bekostigde opleidingen in de schoolverlatersenquête.

Het slagersbedrijf betreft de werkenden in de bedrijfsklassen Detailhandel in vlees en vleeswaren (SBI 5222.1) of Slachterijen, excl. pluimvee- (SBI 1511) die het beroep van slager-verkoper of slachter uitoefenen ${ }^{27}$. Een opmerkelijk gegeven onder de schoolverlaters die in een bedrijfsklasse van het slagersbedrijf (voornamelijk in de detailhandel) of in een beroep van het slagersbedrijf (voornamelijk als Slager-verkoper, lager, SBC 27101) gaan werken is hun opleidingsachtergrond. De opleidingen van deze werkende schoolverlaters is geheel verschillend van de opleidingen die ogenschijnlijk bestemd zijn voor het slagersbedrijf of de vleesbranche. Het is derhalve niet verwonderlijk dat meer dan de helft van de schoolverlaters die als slager-verkoper in de detailhandel werken het vereiste opleidingsniveau van hun baan als lager dan hun werkelijke opleidingsniveau aanmerkt en dat deze schoolverlaters de aansluiting tussen hun opleiding en hun huidige bezigheid als matig of slecht beoordelen. Bijna alle schoolverlaters die als slager-verkoper werkzaam zijn geven aan dat een speciale opleidingsrichting niet vereist werd voor de uitoefening van hun beroep.

\section{Tandtechnisch laboratoriumbedrijf}

Er is geen regulier bekostigde voltijds dagopleiding voor het tandtechnisch laboratoriumbedrijf. Er zijn opleidingen in het leerlingwezen tot Assistent-tandtechnicus (primair) en Tandtechnicus (secundair). Er zijn geen schoolverlaters die in de bedrijfsklasse Tandtechnische bedrijven (SBI 3310.1) of in het beroep Tandtechnicus (SBC 49305) zijn gaan werken.

\section{Tapijtherstellingsbedrijf}

Er zijn geen opleidingen voor het tapijtherstellingsbedrijf. Er zijn geen schoolverlaters in het databestand die in het tapijtherstellingsbedrijf zijn gaan werken. Het tapijtherstellingsbedrijf valt onder dezelfde bedrijfsklasse (SBI 5274) als andere reparatiebedrijven ten behoeve van particulieren (n.I. het fietsherstellersbedrijf, het muziekinstrumenten-

26. Deze opleidingen zijn niet alleen bestemd voor beroepsbeoefenaren in het slagersbedrijf. De vleesbranche onderscheidt naast het slagersbedrijf ook de vleesbe- en verwerkende industrie en de pluimvee-industrie.

27. Zie bijlage B voor een uitgebreide opsomming van beroepen. 
makersbedrijf, het naaimachinebedrijf, het kledingreparatiebedrijf en het zakkenstopbedrijf).

\section{Textielveredelingsbedrijf}

Er is geen regulier bekostigde voltijds dagopleiding voor het textielveredelingsbedrijf (Textielveredeling, SBI 1730). Er zijn diverse opleidingen in het leerlingwezen voor het textielveredelingsbedrijf, n.l. (Assistent)operator veredeling in het primaire leerlingwezen en Textielspecialist mechanische textielvervaardiging en Textielspecialist veredeling in het secundaire leerlingwezen. Er zijn schoolverlaters in de enquête die in het textielveredelingsbedrijf zijn gaan werken.

\section{Toneelkappersbedrijf}

$\mathrm{Er}$ is geen regulier bekostigde votijds dagopleiding tot toneelkapper. Bovendien vallen het beroep en de bedrijfsklasse waarin toneelkappers werkzaam zijn samen met het beroep en de bedrijfsklasse van zowel de kappers als de grimeurs. De toneelkappers zijn wat betreft de uitoefening van hun vak niet te onderscheiden van de kappers (zie voor verdere informatie het kappersbedrijf). In de bedrijfsklasse Dienstverlening t.b.v. kunstbeoefening en organisatie van culturele evenementen (SBI 9302.2) waarin volgens de Standaard Bedrijfs Indeling (bijlage A) toneelkappers werkzaam zouden moeten zijn, vinden voornamelijk schoolverlaters met een technische of economische achtergrond werk.

\section{Uurwerkmakersbedrijf}

Er zijn diverse opleidingen voor het uurwerkmakersbedrijf, n.I. LTO Overige uurwerk, MTO Uurwerktechniek en MBO Fijne techniek Uurwerktechniek. Er zijn te weinig schoolverlaters van deze opleidingen in het databestand om conclusies te trekken. Bovendien zijn er geen schoolverlaters uit de enquête werkzaam in het uurwerkwerkmakersbedrijf (Reparatie van uurwerk en juweliersartikelen, SBI 5273).

\section{Voetverzorgingsbedrijf}

Voor het voetzorgingsbedrijf zijn er regulier bekostigde voltijds dagopleidingen. Binnen de verzorgende opleidingen van het $M D G O$ en het $M B O$ bestaan er drie verwante opleidingen voor haarverzorging, schoonheidsverzorging en voetverzorging. Er zijn geen schoolverlaters uit de steekproef die de voetverzorging als opleidingsrichting hebben. Het voetverzorgingsbedrijf valt onder dezelfde bedrijfsklasse, Schoonheidsverzorging, voetverzorgers en manicures (SBI 9302.2), als het schoonheidsverzorgingsbedrijf. Binnen deze bedrijfsklasse is het voetverzorgingsbedrijf te onderscheiden van het schoonheidsverzorgingsbedrijf door het beroep als afbakening te gebruiken. Binnen deze bedrijfsklasse valt het beroep van de voetverzorgers onder Manicure, voetver- 
zorger, kappershulp en schoonheidsmasseur sauna (SBC 37210), terwijl het beroep van de schoonheidsspecialisten valt onder Kapper, pruikenmaker, grimeur, schoonheidsspecialist (SBC 57212). Er zijn te weinig schoolverlaters die in het voetverzorgingsbedrijf terecht komen om harde conclusies te trekken. Het is echter duidelijk dat de opleidingen voor het voetverzorgingsbedrijf sterk verwant zijn aan de opleidingen voor het kappers- en schoonheidsverzorgingsbedrijf ${ }^{28}$.

\section{Weverij en tapijtknoperij}

Er zijn geen regulier bekostigde opleidingen voor de weverij en tapijtknoperij. Er zijn in de schoolverlatersenquête geen schoolverlaters die in deze branche (Weven van textiel, SBI 172 en Vervaardiging van vloerkleden en tapijt, SBI 1751) zijn gaan werken.

\section{Zadelmakersbedrijf}

Er zijn geen opleidingen voor het zadelmakersbedrijf. De bedrijfsklasse waartoe het zadelmakersbedrijf behoort valt samen met de bedrijfsklasse van het lederwarenambacht (SBI 1920, Vervaardiging van lederwaren, excl. kleding en schoeisel). De beroepen die in deze branches worden uitgeoefend vallen grotendeels samen met de beroepen van het schoenherstellersbedrijf. Er zijn geen schoolverlaters in de enquête die in het zadelmakersbedrijf zijn gaan werken.

\section{Zakkenstopbedrijf}

Er zijn geen opleidingen voor het zakkenstopbedrijf. Het zakkenstopbedrijf valt gedeeltelijk onder dezelfde bedrijfsklasse (SBI 5274) als andere reparatiebedrijven ten behoeve van particulieren (n.l. het fietsherstellersbedrijf, het kledingreparatiebedrijf het muziekinstrumentenmakersbedrijf, het naaimachinebedrijf en het tapijtherstellingsbedrijf). Een ander gedeelte van het zakkenstopbedrijf valt onder de bedrijfsklasse Vervaardiging van textielwaren, excl. kleding, SBI 1740). Ook de beroepen in het zakkenstopbedrijf vallen samen met andere beroepen. Er zijn geen schoolverlaters in de schoolverlatersenquête die in het zakkenstopbedrijf zijn gaan werken.

28. Daarnaast spelen particuliere opleidingen een belangrijke rol voor het voetverzorgingsbedrijf. 


\section{Kenmerken van werkenden in ambachtelijke branches}

In dit hoofdstuk wordt gekeken naar de kenmerken van de werkenden in de onderscheiden ambachten. Om hierover tot een goed oordeel te kunnen komen worden het aantal werkenden in de ambachten, hun beroep, opleidingsachtergrond en leeftijd weergegeven. Per ambacht worden de meest voorkomende opleidingen en beroepen in volgorde van belangrijkheid vermeld. De opleidingsachtergrond van werkenden in dit hoofdstuk is niet langer beperkt tot alleen de regulier bekostigde opleidingen (zoals in hoofdstuk 2), maar betreft ook de particuliere opleidingen. Op basis van een vergelijking van de gegevens uit dit hoofdstuk met de gegevens uit de schoolverlatersenquête in hoofdstuk 2, worden conclusies getrokken over de kenmerken van schoolverlaters die in een ambacht instromen ten opzichte van de kenmerken van de andere werkenden.

Voorts wordt gekeken naar overige kenmerken van werkenden in de ambachten, zoals het aandeel vrouwen en allochtonen, het aandeel werknemers met een flexibel contract, het aandeel deeltijdwerkers en het aandeel zelfstandigen ${ }^{29}$. Deze kenmerken worden vergeleken met de kenmerken van werkenden in alle ambachten tezamen en in de totale beroepsbevolking (zie hiervoor bijlage $\mathrm{C}$ ).

De gegevens in dit hoofdstuk zijn gebaseerd op de Enquête Beroepsbevolking (EBB) van het CBS. De gegevens in dit hoofdstuk hebben betrekking op het gemiddelde van 1994 en 1995. Per paragraaf worden de kenmerken van de werkenden in een ambacht behandeld. De gegevens uit de EBB zijn afgerond op 500 en hebben een ondergrens van 2.500. Hierdoor ontstaat bij de berekening van procentuele aandelen van werkenden met een bepaald kenmerk (bijvoorbeeld geslacht) met name voor de kleinere ambachten een behoorlijke foutmarge. Voor deze kleinere ambachten zal aan afwijkingen van minder dan $5 \%$ ten opzichte van de gemiddelde aandelen in bijlage $C$ geen aandacht worden geschonken. Gegevens die onder de ondergrens vallen van 2.500 kunnen vanwege de restricties die het CBS oplegd (zie hoofdstuk 1) niet worden weergegeven in de tabellen. De ontbrekende gegevens worden aangemerkt met een horizontaal streepje (-). De paragraafindeling is dezelfde als in hoofdstuk 2. Ambachten waarover onvoldoende informatie beschikbaar is, worden echter niet genoemd.

\section{Banketbakkersbranche}

Het overgrote deel, namelijk $96 \%$, van het totale aantal werkenden in de branche van het banketbakkersbedrijf ( 42.500 werkenden) heeft een baan in de broodfabrieken en brood- en banketbakkerijen met verkoop in de winkel (SBI 1581) of in de banketfabrieken (SBI 1582). Het overige, kleine, deel werkt in de detailhandel in brood en

29. Zie hoofdstuk 1 voor een verklaring van de begrippen 'allochtoon' en 'flexibel contract'. Overigens moeten werkenden volgens de definitie van het CBS minstens 12 uur per week werken. 
banket (SBI 5224.1). Daarentegen is uit hoofdstuk 2 gebleken dat schoolverlaters (excl. leerlingwezen) die in het banketbakkersbedrijf gaan werken juist vaak terecht komen in de detailhandel, onder meer als winkelbediende. Deze schoolverlaters hebben veelal een economisch of administratieve opleidingsachtergrond (zie paragraaf 2.1). Tabel 3.1 geeft informatie over de opleidingsachtergrond, het beroep en de leeftijd van alle werkenden in het banketbakkersbedrijf. Uit deze tabel blijkt dat slechts $12 \%$ van de werkenden in deze branche een economisch of administratieve opleidingsachtergrond heeft en dat iets meer dan een kwart werkt als winkelbediende.

Tabel 3.1

De banketbakkersbranche naar opleiding, beroep en leeftijd

Kenmerk

opleiding

MBO/LLW Techniek/ Consumptieve Techniek

VBO Techniek/ Consumptieve Techniek 13

Basisonderwijs 13

MBO/LLW Economisch en administratief 12

VBO Verzorging

MAVO, onderbouw HAVONWO
overige opleidingen

beroep

ambachtelijk brood- en banketbakker, middelbaar (excl. in-, verkoop)

winkelbediende, straatverkoper, e.d.

ambachtelijk brood- en banketbakker, lager (excl. in-, verkoop) $\quad 8$

lager technisch personeel
overige beroepen

leeftijd

jonger (15-29 jr.) $\quad 45$

middelbaar (30-49 jr.) 42

$\begin{array}{lr}\text { ouder (50-64 jr.) } & 12\end{array}$

Bron: CBS/ROA

Uit tabel 3.1 blijkt verder dat het aandeel jongere werkenden in het banketbakkersbedrijf groot is, zowel ten opzichte van alle werkenden in de ambachtelijke branches als ten opzichte van de totale beroepsbevolking (zie tabel C.4 in bijlage C). Dit cijfer spoort met de relatief grote instroom van schoolverlaters in het banketbakkersbedrijf. Er kan voorzichtig geconcludeerd worden dat vooral voor de werkende jongeren in het banketbakkersbedrijf geldt dat ze geen bakkersopleiding maar een economisch of administratieve opleiding hebben, en dat ze niet als bakker maar als winkelbediende in de detailhandel werken ${ }^{30}$.

30. Er moet hierbij wel aangetekend worden dat de schoolverlaters die een opleiding in het leerlingwezen hebben afgesloten en vervolgens een baan vinden, niet door de schoolverlatersenquête worden geregistreerd. Het is goed voorstelbaar dat schoolverlaters die een banketbakkersopleiding in het leerlingwezen hebben afgesloten als ambachtelijk bakker gaan werken. 
Verder blijkt uit tabel 3.1 dat $37 \%$ van de werkenden een technische opleiding heeft op $M B O / L L W$ - of VBO-niveau. Veelal zullen deze werkenden een opleiding in de consumptieve techniek doorlopen hebben, waaronder de opleidingen voor het banketbakkersbedrijf (zie hoofdstuk 2). Ongeveer tweevijfde van de werkenden in het banketbakkersbedrijf is daadwerkelijk werkzaam als brood- of banketbakker.

Tabel 3.2 geeft de kenmerken van werkenden in het banketbakkersbedrijf weer. Het aandeel vrouwen in het banketbakkersbedrijf komt ongeveer overeen met het aandeel vrouwen in het totaal van ambachten. Dit is hoger dan het aandeel vrouwen in de totale beroepsbevolking (zie tabel C.4 in bijlage C). De aandelen Nederlandse werkenden, vaste en flexibele werkenden en zelfstandigen in het banketbakkersbedrijf komen ongeveer overeen met de respectievelijke aandelen in de totale beroepsbevolking. Het aandeel zelfstandigen ligt in het banketbakkersbedrijf echter lager dan in de andere ambachten. Het aandeel deeltijdwerkers in het banketbakkersbedrijf ligt tussen dat van de ambachten en de totale beroepsbevolking in.

Tabel 3.2

Overige kenmerken van werkenden in de banketbakkersbranche

\begin{tabular}{lc}
\hline Kenmerk & $\%$ \\
\hline geslacht & \\
man & 56 \\
vrouw & 44 \\
etniciteit & \\
Nederlands & 92 \\
allochtoon & 6 \\
overige buitenlanders & 2 \\
positie werkkring & \\
vast ( $>1$ jr.) & 81 \\
flexibel (<1 jr.) & 7 \\
zelfstandig & 12 \\
lengte werkweek & \\
voltijd $(>32$ uur) & \\
deeltijd $(\leq 32$ uur) & 71 \\
\end{tabular}

Bron: CBS/ROA

\section{Dakdekkersbranche}

Het beroep dakdekker omvat het aanbrengen van bedekking, waaronder pannen, lei, mastiek en stro en riet, en het renoveren zonder elementen (SBC 26219). Indien er sprake is van het renoveren met elementen valt het beroep van dakdekker onder een andere beroepsklasse (SBC 26211, zie bijlage B). Het beroep dakdekker wordt hoofdzakelijk uitgeoefend in de dakdekkersbranche (SBI 4522), waarin ongeveer 9.000 personen werken. De eerstgenoemde beroepsklasse van dakdekkers is in deze branche met ongeveer 5.500 werkenden verreweg de grootste. Deze beroepsklasse 
telt in totaal eigenlijk ongeveer 6.500 werkenden, hetgeen impliceert dat ongeveer 1.000 dakdekkers buiten de branche van het dakdekkersbedrijf werkzaam zijn. Overigens telt de beroepsklasse van dakdekkers die renoveren met elementen (SBC 26211) in elk geval niet meer dan 1.000 werkenden in de branche van het dakdekkersbedrijf.

Tabel 3.3 geeft de kenmerken weer van werkenden in de dakdekkersbranche met betrekking tot hun opleidingsachtergrond, beroep en leeftijd. Hoewel de opleidingsachtergrond van de werkenden in het dakdekkersbedrijf divers is, komt de opleiding VBO Techniek het meest voor (28\%). Voorts oefent $61 \%$ van de werkenden in de dakdekkersbranche het beroep dakdekker uit. Uit de achterliggende gegevens blijkt dat een veel groter aandeel van deze dakdekkers in de dakdekkersbranche de opleiding VBO Techniek als opleidingsachtergrond heeft. Ongeveer 3.000 van de 6.500 dakdekkers heeft VBO Techniek als opleidingsachtergrond, hetgeen overeenkomt met $46 \%$. Dit is vooral opmerkelijk omdat er binnen de opleiding VBO Techniek geen vooropleiding tot dakdekker bestaat ${ }^{31}$. Verder is het aandeel jongeren in de dakdekkersbranche relatief hoog ten opzichte van het gemiddelde aandeel jongeren in de ambachtelijke branches en de totale beroepsbevolking (zie tabel C.4 in bijlage C). Daarentegen is de instroom van (jonge) schoolverlaters in het dakdekkersbedrijf volgens de schoolverlatersenquête (zie paragraaf 2.5) laag.

Tabel 3.3

De dakdekkersbranche naar opleiding, beroep en leeftijd

\begin{tabular}{lr}
\hline Kenmerk & $\%$ \\
\hline opleiding & \\
VBO Techniek & 28 \\
overige opleidingen & 72 \\
beroep & 61 \\
dakdekker & 39 \\
overige beroepen & \\
leeftijd & 44 \\
jonger (15-29 jr.) & 50 \\
middelbaar (30-49 jr.) & 6 \\
ouder (50-64 jr.) & \\
\hline
\end{tabular}

Bron: CBS/ ROA

Tabel 3.4 laat de overige kenmerken van werkenden in de dakdekkersbranche zien. Het aandeel mannen blijkt in de dakdekkersbranche beduidend hoger te zijn dan in de rest van de beroepsbevolking (ambachtelijk en niet-ambachtelijk). Het aandeel werkenden met een voltijdse baan is hoger dan in de rest van de ambachten. De

31. Alleen binnen het leerlingwezen (dat gerekend wordt tot het MBO-niveau) bestaat een dergelijke opleiding (zie paragraaf 2.5). 
aandelen werkenden van Nederlandse afkomst of met een vaste baan in de dakdekkersbranche zijn ongeveer gelijk aan de respectievelijke aandelen in de beroepsbevolking.

Tabel 3.4

Overige kenmerken van werkenden in de dakdekkersbranche

\begin{tabular}{lc}
\hline Kenmerk & $\%$ \\
\hline geslacht & \\
man & 89 \\
vrouw & 11 \\
etniciteit & \\
Nederlands & 94 \\
allochtoon & - \\
overig & - \\
positie werkkring & \\
vast $(\geq 1$ jr.) & 78 \\
flexibel (<1 jr.) & - \\
zelfstandig & - \\
lengte werkweek & \\
voltijd $(>32$ uur) \\
deeltijd $(\leq 32$ uur)
\end{tabular}

Bron: CBS/ ROA

\section{Fietsherstellersbranche}

De fietsherstellersbranche omvat twee bedrijfsklassen, Reparatie t.b.v. particulieren n.e.g. (SBI 5274) en Detailhandel in fietsen (SBI 5248.5). De eerstegenoemde bedrijfsklasse maakt ook deel uit van andere branches, terwijl bovendien het beroep van

Tabel 3.5

De fietsherstellersbranche naar opleiding, beroep en leeftijd

\begin{tabular}{ll} 
Kenmerk & $\%$ \\
\hline opleiding & - \\
- & \\
beroep & 50 \\
fietsenmaker & 50 \\
overige beroepen & \\
leeftijd & \\
jonger (15-29 jr.) \\
middelbaar (30-49 jr.) \\
ouder (50-64 jr.) & - \\
\hline Bron: CBS/ ROA & - \\
\hline
\end{tabular}


fietsenmaker (SBC 26505) weinig voorkomt in deze bedrijfsklasse. De tweede bedrijfsklasse maakt met ongeveer 5.000 werkenden uitsluitend deel uit van de fietsherstellersbranche.

Uit tabel 3.6 blijkt dat werkenden in de fietsherstellersbranche relatief vaak van het mannelijke geslacht en van Nederlandse afkomst zijn. Bovendien zijn zij relatief vaak zelfstandige met een voltijds baan.

Tabel 3.6

Overige kenmerken van werkenden in de fietsherstellersbranche

\begin{tabular}{lc}
\hline Kenmerk & $\%$ \\
\hline geslacht & 80 \\
man & 20 \\
vrouw & \\
etniciteit & 100 \\
Nederlands & 0 \\
allochtoon & 0 \\
overig & \\
positie werkkring & - \\
vast $(<1$ jr.) & - \\
flexibel (<1 jr.) & 50 \\
zelfstandig & \\
lengte werkweek & 80 \\
voltijd (>32 uur) & \\
deeltijd ( $\leq 32$ uur) & 20 \\
\hline
\end{tabular}

Bron: CBS/ ROA

\section{Glazenwassers- en schoonmaakbranche}

Het beroep glazenwasser valt in een bredere beroepsgroep met bijv. interieurverzorgers, medewerkers huishoudelijke dienst en schoonmakers (SBC 11133), terwijl ook de branche van het glazenwassersbedrijf in een bredere bedrijfsklasse valt (Reiniging van gebouwen, SBI 7470.1). De combinatie van beroep en bedrijfsklasse resulteert in 33.000 werkenden die het beroep van glazenwasser of schoonmaker uitoefenen. De glazenwassers zijn met behulp van de CBS-classificaties niet te onderscheiden van de schoonmakers van bedrijven en instellingen ${ }^{32}$. In de navolgende tabellen worden de kenmerken van de werkenden weergegeven in de bedrijfsklasse waaronder niet alleen het glazenwassersbedrijf valt, maar gedeeltelijk ook de schoonmakers en de schoorsteenvegers (SBC 11111, zie hiervoor paragraaf 3.28). In deze bedrijfsklasse werken 48.000 personen, onder wie de glazenwassers en schoonmakers veruit de grootste beroepsgroep zijn.

32. Niet alle schoonmakers vallen onder de genoemde 33.000 werkenden. 
Uit tabel 3.7 blijkt dat ongeveer eenderde van de werkenden in de glazenwassers- en schoonmaakbranche slechts basisonderwijs heeft genoten. Hieronder vallen ook schoolverlaters die een opleiding na het basisonderwijs zonder diploma verlaten. Dit komt overeen met paragraaf 2.10 waaruit bleek dat het diplomabezit onder schoolverlaters die in het glazenwassers- en schoonmaakbedrijf werken relatief laag is. Voorts blijkt uit tabel 3.7 dat minstens eenderde van de glazenwassers en schoonmakers slechts een lagere opleiding heeft (VBO Verzorging, MAVO, HAVO onderbouw of VBO Techniek). Tabel 3.7 laat verder zien dat de leeftijdsopbouw van de werkende glazenwassers en schoonmakers overeenkomt met de leeftijdsopbouw van de totale beroepsbevolking (tabel C.4 in bijlage C). Het aandeel jongeren onder de werkenden is in het glazenwassers- en schoonmaakbedrijf is wel beduidend lager dan onder de werkenden in alle ambachten (zie tabel C.4).

Tabel 3.7

De glazenwassers- en schoonmaakbranche naar opleiding en leeftijd

\begin{tabular}{lc}
\hline Kenmerk & $\%$ \\
\hline & \\
opleiding & 32 \\
Basisonderwijs & 16 \\
VBO Verzorging & 10 \\
MAVO, onderbouw HAVO/ VWO & 7 \\
VBO Techniek & 7 \\
MBO/ LLW Economisch en administratief & 6 \\
MBO/ LLW Verzorgend & 22 \\
overige opleidingen & \\
leeftijd & 33 \\
jonger (15-29 jr.) & 56 \\
middelbaar (30-49 jr.) & 11 \\
ouder (50-64 jr.) &
\end{tabular}

Bron: CBS/ROA

Opm.: Het beroep wordt hier niet weergegeven omdat het glazenwassersbedrijf is afgebakend door de beroepsgroep van de glazenwassers. De kenmerken van de glazenwassers met betrekking tot opleiding en leeftijd zijn gebaseerd op de hele bedrijfsklasse Reiniging van gebouwen (SBI 7470.1) waaronder het glazenwassersbedrijf valt.

Tabel 3.8 geeft de overige kenmerken van werkenden in de glazenwassers- en schoonmaakbranche weer. Er blijken relatief veel vrouwen, allochtonen en overige buitenlanders te werken. Verder werkt een opmerkelijk groot deel, namelijk drievijfde, van de werkenden in deeltijd. Het aandeel werkenden met een vast dienstverband in de glazenwassers- en schoonmaakbranche komt overeen met het aandeel in de totale beroepsbevolking, maar ligt hoger dan het gemiddelde aandeel in de ambachten.

Concluderend kan gesteld worden dat de glazenwassers- en schoonmaakbranche zich kenmerkt door relatief veel laagopgeleide en vrouwen die relatief vaak van allochtone of buitenlandse afkomst zijn en die voornamelijk in deeltijd werken. 
Tabel 3.8

Overige kenmerken van werkenden in de glazenwassers- en schoonmaakbranche

\begin{tabular}{lc}
\hline Kenmerk & $\%$ \\
\hline geslacht & 39 \\
man & 61 \\
vrouw & \\
etniciteit & 77 \\
Nederlands & 14 \\
allochtoon & 10 \\
overig & \\
positie werkkring & 80 \\
vast ( $(1$ jr.) & 13 \\
flexibel (<1 jr.) & 7 \\
zelfstandig & \\
lengte werkweek & 39 \\
voltijd (>32 uur) & \\
deeltijd ( 32 uur) & 61 \\
\hline
\end{tabular}

Bron: CBS/ROA

\section{Kappersbranche}

De kappersbranche wordt geheel weerspiegeld door de bedrijfsklasse Kappers (SBI 9302.1). Deze bedrijfsklasse telt 29.000 werkenden. Tabel 3.9 geeft de kenmerken van deze werkenden weer met betrekking tot opleiding, beroep en leeftijd. De opleidingsachtergrond van kappers is voor meer dan viervijfde $M B O / L L W$ Verzorging of Uiterlijke verzorging ${ }^{33}$. Haast vanzelfsprekend werkt het overgrote deel van de werkenden in de kappersbranche als kapper. Het overige deel werkt waarschijnlijk als kappershulp (SBC 37210 , zie ook paragraaf 2.13). Verder blijkt onder de kappers een meer dan twee keer zo groot aandeel ten opzichte van de totale beroepsbevolking (zie tabel C.4) tot de jongere leeftijdsgroep te behoren. Dit verklaart ook de relatief grote instroom van schoolverlaters in de kappersbranche volgens de schoolverlatersenquête (hoofdstuk 2).

Tabel 3.10 laat de overige kenmerken van werkenden in de kappersbranche zien. In de kappersbranche blijken vooral veel vrouwen te werken (79\%), maar relatief weining allochtonen en overige buitenlanders. Verder blijkt dat relatief veel werkenden zelfstandige zijn (38\%). Werkenden die in dienst werken bij een zelfstandige blijken vrijwel altijd een vast dienstverband te hebben. Ongeveer de helft van kappers heeft een voltijdse werkweek. De andere helft heeft een deeltijdbaan, hetgeen relatief hoog is ${ }^{34}$.

33. Zie paragraaf 2.13 voor een opsomming van verzorgende opleidingen (waaronder ook MDGOopleidingen) voor het kappersbedrijf. Verder wordt een niet onbelangrijk deel van de opleidingen voor het kappersbedrijf doorlopen binnen het leerlingwezen (LLW). In de EBB worden deze opleidingen allemaal geclassificeerd als $M B O / L L W$-opleidingen.

34. Zie bijlage $\mathrm{C}$ voor een vergelijking met andere ambachten en met de totale beroepsbevolking. 
Tabel 3.9

De kappersbranche naar opleiding, beroep en leeftijd

\begin{tabular}{lc}
\hline Kenmerk & $\%$ \\
\hline opleiding & \\
MBO/ LLW Verzorging & 55 \\
MBO/ LLW Uiterlijke verzorging & 28 \\
overige opleidingen & 17 \\
beroep & \\
kapper & 91 \\
overige beroepen (vooral kappershulp) & 9 \\
leeftijd & \\
jonger (15-29 jr.) & 62 \\
middelbaar (30-49 jr.) & 31 \\
ouder (50-64 jr.) & 7 \\
\hline Bron: CBS/ ROA & \\
\hline
\end{tabular}

Bron: CBS/ROA

Tabel 3.10

Overige kenmerken van werkenden in de kappersbranche

\begin{tabular}{lc}
\hline Kenmerk & $\%$ \\
\hline geslacht & 21 \\
man & 79 \\
vrouw & \\
etniciteit & 95 \\
Nederlands & - \\
allochtoon & - \\
overig & \\
positie werkkring & 60 \\
vast ( 1 jr.) & 2 \\
flexibel (<1 jr.) & 38 \\
zelfstandig & \\
lengte werkweek & \\
voltijd (>32 uur) & \\
deeltijd ( $\leq 32$ uur) & 52 \\
\hline Bron: CBS/ROA & 48 \\
\hline
\end{tabular}

Bron: CBS/ROA

\section{Optiekbranche}

De optiekbranche valt onder twee bedrijfsklassen, namelijk Vervaardiging van optische instrumenten, foto- en filmapparatuur (SBI 3340) en Detailhandel in optische artikelen (SBI 5248.2). Deze bedrijfsklassen tellen tezamen ongeveer 7.500 werkenden, van wie ongeveer 5.500 in de detailhandel werken. Tabel 3.11 laat de opleidingsachtergrond, het beroep en de leeftijd van deze werkenden zien. Uit deze tabel blijkt dat bijna de helft van de werkenden in de optiekbranche daadwerkelijk het beroep van opticien of optometrist uitoefent. De andere helft van de werkenden heeft mogelijk een verkoop- 
Tabel 3.11

De optiekbranche naar opleiding, beroep en leeftijd

\begin{tabular}{lc}
\hline Kenmerk & $\%$ \\
\hline $\begin{array}{l}\text { opleiding } \\
\text { MBO/ LLW Medisch laboratorium (waaronder Optiek en Opticien) } \\
\text { overige opleidingen }\end{array}$ & 33 \\
beroep & 67 \\
opticien, optometrist & \\
overige beroepen & 47 \\
leeftijd & 53 \\
jonger (15-29 jr.) & \\
middelbaar (30-49 jr.) & 33 \\
ouder (50-64 jr.) & 53 \\
\hline
\end{tabular}

Bron: CBS/ ROA

Tabel 3.12

Overige kenmerken van werkenden in de optiekbranche

\begin{tabular}{lc}
\hline Kenmerk & $\%$ \\
\hline geslacht & 64 \\
man & 36 \\
vrouw & \\
etniciteit & 93 \\
Nederlands & - \\
allochtoon & - \\
overig & \\
positie werkkring & 80 \\
vast ( 1 jr.) & \\
flexibel (<1 jr.) & - \\
zelfstandig & - \\
lengte werkweek & \\
voltijd $(>32$ uur) \\
deeltijd $(\leq 32$ uur)
\end{tabular}

Bron: CBS/ROA

functie. Eenderde van de werkenden heeft een middelbare voltijds dagopleiding of opleiding in het leerlingwezen voor het optiekbedrijf achter de rug ${ }^{35}$. De leeftijdsopbouw van de werkenden in het optiekbedrijf komt ongeveer overeen met de leeftijdsopbouw van de totale beroepsbevolking. Er werkt een enigzins lager percentage jongeren in de optiekbranche dan in het totaal van ambachten (zie bijlage $\mathrm{C}$ ). Dit verklaart mogelijk de

35. Zie hoofdstuk 2 voor de exacte benamingen van de opleidingen voor het optiekbedrijf. Overigens blijkt bij nadere analyse dat ongeveer de helft van de werkenden die het beroep van opticien of optometrist uitoefenen een middelbare opleiding voor het optiekbedrijf heeft afgesloten. 
lage instroom van schoolverlaters in het optiekbedrijf (zie hoofdstuk 2).

Tabel 3.12 laat de overige kenmerken van werkenden in de optiekbranche zien. Het aandeel mannen en Nederlanders en het aandeel werkenden met een voltijdse werkweek en een vast contract komt overeen met de aandelen in de totale beroepsbevolking, maar zijn hoger ten opzichte van het totaal van ambachten.

\section{Parketvloerleggersbranche}

De parketvloerleggersbranche valt onder de bedrijfsklasse Afwerken van vloeren en wanden $(\mathrm{SBI} 4543)^{36}$. Deze bedrijfsklasse telt ongeveer 10.000 werkenden $^{37}$. Tabel 3.13 geeft nadere informatie over opleiding, beroep en leeftijd van deze groep. Het blijkt dat ongeveer $65 \%$ als parket(vloer)legger werkzaam is. Ongeveer $25 \%$ heeft de opleiding VBO Techniek afgesloten. De leeftijdsopbouw van de werkenden in het parketvloerleggersbranche komt ongeveer overeen met de leeftijdsopbouw in het totaal van ambachten. Er werkt een enigzins hoger percentage jongeren in de parketvloerleggersbranche dan in de totale beroepsbevolking (zie bijlage $C$ ).

Tabel 3.13

De parketvloerleggersbranche naar opleiding, beroep en leeftijd

\begin{tabular}{lc}
\hline Kenmerk & $\%$ \\
\hline $\begin{array}{l}\text { opleiding } \\
\text { VBO Techniek } \\
\text { overige opleidingen }\end{array}$ & 25 \\
beroep & 75 \\
parket(vloer)legger & \\
overige beroepen & 65 \\
leeftijd & 35 \\
jonger (15-29 jr.) & \\
middelbaar (30-49 jr.) & 35 \\
ouder (50-64 jr.) & 50 \\
\hline
\end{tabular}

Bron: CBS/ ROA

Tabel 3.14 geeft de overige kenmerken van werkenden in de parketvloerleggerbranche weer. Het aandeel werkenden van het mannelijke geslacht, als zelfstandige en voltijds werkend blijkt relatief heel hoog te zijn. Het aandeel werkenden van Nederlandse afkomst blijkt overeen te komen met zowel ambachtelijke als niet-ambachtelijke

36. De bedrijfsklasse Detailhandel in parket-, laminaat- en kurkvloeren (SBI 5246.6) valt volgens opgave van het HBA niet onder de ambachten.

37. Slechts een deel van de werkenden in deze bedrijfsklasse oefent het beroep van parketvloerlegger uit (zie ook hoofdstuk 1). Volgens opgave van het EIM (1997) bedraagt het aantal parketvloerleggers ongeveer 2.400 . 
branches (zie bijlage C).

Tabel 3.14

Overige kenmerken van werkenden in de parketvloerleggersbranche

\begin{tabular}{lc}
\hline Kenmerk & $\%$ \\
\hline geslacht & 90 \\
man & 10 \\
vrouw & \\
etniciteit & 90 \\
Nederlands & - \\
allochtoon & - \\
overig & \\
positie werkkring & 5 \\
vast $(21$ jr.) & 65 \\
flexibel (<1 jr.) & 30 \\
zelfstandig & \\
lengte werkweek & 95 \\
voltijd $(>32$ uur) \\
deeltijd $(\leq 32$ uur) & 5 \\
\hline
\end{tabular}

Bron: CBS/ROA

\section{Schoonheids- en voetverzorgingsbranche}

De schoonheidsverzorgingsbranche valt onder dezelfde bedrijfsklasse als de voetverzorgingsbranche, namelijk Schoonheidsverzorging, voetverzorgers en manicures (SBI 9302.2). De branche van het schoonheidsverzorgingsbedrijf kan door het beroep schoonheidsspecialiste (SBC 57212) worden afgebakend van de branche van het voetverzorgingsbedrijf (SBC 37210), waar voetverzorger (SBC 37210) het relevante beroep is. De branche van het schoonheidsverzorgingsbedrijf telt ongeveer 4.000 werkenden, terwijl de branche van het voetverzorgingsbedrijf ongeveer 3.000 werkenden telt ${ }^{38}$. Deze twee branches kunnen echter niet verder worden onderscheiden naar kenmerken van de werkenden. Deze gegevens betreffen daarom de twee branches tezamen.

Tabel 3.15 presenteert de kenmerken van werkenden in de schoonheids- en voetverzorgingsbranche betreffende hun opleiding, beroep en leeftijd. Over de opleidingsachtergrond zijn geen gegevens beschikbaar. Er is wel bekend dat de opleidingsachtergrond van de beroepsgroep waaronder zowel schoonheidsspecialisten als kappers vallen vooral MBO Verzorging en MBO Uiterlijke verzorging is.

38. Hierbij dient te worden aangetekend dat met behulp van enkel de Standaard Bedrijfsindeling en de Standaard Beroepenclassificatie de voetverzorgers niet kunnen worden onderscheiden van de manicures, terwijl de schoonheidsspecialisten niet kunnen worden onderscheiden van de grimeurs. 
Tabel 3.15

De schoonheidsverzorgings- en voetverzorgingsbranche naar opleiding, beroep en leeftijd

\begin{tabular}{lc}
\hline Kenmerk & $\%$ \\
\hline opleiding & - \\
- & 53 \\
beroep & 40 \\
schoonheidsspecialiste & 7 \\
voetverzorger & \\
overige beroepen & \\
leeftijd & - \\
jonger (15-29 jr.) & 60 \\
middelbaar $(30-49$ jr.) & - \\
\hline ouder (50-64 jr.) & \\
\hline
\end{tabular}

Bron: CBS/ ROA

Tabel 3.16 presenteert de overige kenmerken van de werkenden in de schoonheidsen de voetverzorgingsbranche. Deze kenmerken zijn zeer uitgesproken. De werkenden in deze branches zijn bijna zonder uitzondering vrouwelijk en doorgaans werkend als zelfstandige. Voorts blijkt bijna driekwart van deze werkenden in deeltijd te werken. Het aandeel werkenden van Nederlandse afkomst komt overeen met de gemiddeldes in ambachtelijke en niet-ambachtelijke branches.

Tabel 3.16

Overige kenmerken van werkenden in de schoonheidsverzorgings- en voetverzorgingsbranche

\begin{tabular}{|c|c|}
\hline Kenmerk & $\%$ \\
\hline \multicolumn{2}{|l|}{ geslacht } \\
\hline $\operatorname{man}$ & 0 \\
\hline vrouw & 100 \\
\hline \multicolumn{2}{|l|}{ etniciteit } \\
\hline Nederlands & 93 \\
\hline allochtoon & - \\
\hline overig & - \\
\hline \multicolumn{2}{|l|}{ positie werkkring } \\
\hline vast ( $21 \mathrm{jr}$.) & - \\
\hline flexibel (<1 jr.) & - \\
\hline zelfstandig & 93 \\
\hline \multicolumn{2}{|l|}{ lengte werkweek } \\
\hline voltijd ( $>32$ uur) & 27 \\
\hline deeltijd ( $\leq 32$ uur) & 73 \\
\hline
\end{tabular}

Bron: CBS/ROA

\section{Slagersbranche}

De slagersbranche omvat twee bedrijfsklassen, namelijk Slachterijen, excl. pluimvee- 
Tabel 3.17

De slagersbranche naar opleiding, beroep en leeftijd

\begin{tabular}{lr} 
Kenmerk & $\%$ \\
\hline opleiding & \\
MBO/ LLW Techniek/ Consumptieve techniek & 32 \\
Basisonderwijs & 14 \\
VBO Techniek/ Consumptieve techniek & 11 \\
VBO Verzorging & 9 \\
MBO/ LLW Economisch en administratief & 9 \\
overige opleidingen & 25 \\
& \\
beroep & 30 \\
slager-verkoper (lager) & 25 \\
slager-verkoper (middelbaar)/ leidinggevend slager-verkoper & 23 \\
verkoper/ winkelbediende & 22 \\
overige beroepen & \\
leeftijd & \\
jonger (15-29 jr.) & 39 \\
middelbaar (30-49 jr.) & 50 \\
ouder (50-64 jr.) & 11
\end{tabular}

Bron: CBS/ ROA

Tabel 3.18

Overige kenmerken van werkenden in de slagersbranche

\begin{tabular}{lc}
\hline Kenmerk & $\%$ \\
\hline geslacht & 66 \\
man & 34 \\
vrouw & \\
etniciteit & 93 \\
Nederlands & - \\
allochtoon & - \\
overige buitenlanders & \\
positie werkkring & 70 \\
vast ( 1 jr.) & 3 \\
flexibel (<1 jr.) & 27 \\
zelfstandig & \\
lengte werkweek & 79 \\
voltijd $(>32$ uur) \\
deeltijd $(\leq 32$ uur) & 21 \\
\hline
\end{tabular}

Bron: CBS/ROA

(SBI 1511) met 9.000 werkenden en Detailhandel in vlees en vleeswaren (SBI 5222.1) met 19.000 werkenden. Tabel 3.17 presenteert de kenmerken van de werkenden in deze branche met betrekking tot hun opleiding, beroep en leeftijd. Meer dan tweevijfde van de werkenden heeft een opleiding consumptieve techniek achter de rug, waaronder veelal de opleidingen die voor de slagersbranche bestemd zijn (zie hiervoor paragraaf 
2.29). Ruimschoots meer dan de helft van de werkenden in de slagersbranche heeft ook daadwerkelijk het beroep slager. Bijna een kwart van de werkenden in de slagersbranche werkt als verkoper of winkelbediende. De leeftijdsopbouw van de werkenden in de slagersbranche spoort met de leeftijdsopbouw van de werkenden in alle ambachten tezamen (zie tabel C.4).

Tabel 3.18 presenteert de overige kenmerken van de werkenden in de slagersbranche. Het aandeel werkende mannen in de slagerbranche is relatief hoog, evenals het aandeel voltijds werkenden. Voorts is het aandeel werkenden met een vast contract laag ten opzichte van aandeel werkenden met een vast contract in de beroepsbevolking. Daarentegen is het aandeel zelfstandigen relatief hoog in de slagersbranche.

\section{Tandtechnische laboratoriumbranche}

De tandtechnische laboratoriumbranche wordt vertegenwoordigd door de bedrijfsklasse Tandtechnische bedrijven (SBI 3310.1), die slechts ongeveer 3.500 werkenden telt. Tabel 3.19 laat het meest dominante beroep onder deze werkenden zien, namelijk het beroep tandtechnicus of tandprotheticus. Deze twee beroep zijn in de classificaties van het CBS niet te onderscheiden.

Tabel 3.19

De tandtechnische laboratoriumbranche naar opleiding, beroep en leeftijd

\begin{tabular}{lc}
\hline Kenmerk & $\%$ \\
\hline opleiding & - \\
- & \\
beroep & 71 \\
tandtechnicus/ tandprotheticus & 29 \\
overige beroepen & \\
leeftijd & \\
jonger (15-29 jr.) & \\
middelbaar $(30-49$ jr.) & - \\
ouder (50-64 jr.) & - \\
\hline
\end{tabular}

Bron: CBS/ ROA

Tabel 3.20 geeft de overige kenmerken van werkenden in de technische laboratoriumbranche weer. Het aandeel mannen in deze branche is hoger dan in de rest van de beroepsbevolking (ambachtelijk en niet-ambachtelijk). De andere kenmerken van werkenden verschillen niet veel van de gemiddelden in de ambachtelijke en nietambachtelijke branche (bijlage C). Het aandeel werkenden van Nederlandse afkomst lijkt in de tandtechnische laboratoriumbranche iets lager te zijn dan in de totale beroepsbevolking. 
Tabel 3.20

Overige kenmerken van werkenden in de tandtechnische laboratoriumbranche

\begin{tabular}{|c|c|}
\hline Kenmerk & $\%$ \\
\hline \multicolumn{2}{|l|}{ geslacht } \\
\hline man & 71 \\
\hline vrouw & 29 \\
\hline \multicolumn{2}{|l|}{ etniciteit } \\
\hline Nederlands & 86 \\
\hline allochtoon & - \\
\hline overige buitenlanders & - \\
\hline \multicolumn{2}{|l|}{ positie werkkring } \\
\hline vast ( $\geq 1$ jr.) & 71 \\
\hline flexibel (<1 jr.) & - \\
\hline zelfstandig & - \\
\hline \multicolumn{2}{|l|}{ lengte werkweek } \\
\hline voltijd ( $>32$ uur) & 71 \\
\hline deeltijd ( $\leq 32$ uur) & 29 \\
\hline
\end{tabular}

Bron: CBS/ROA

\section{Textielveredelingsbranche}

De textielveredelingsbranche wordt vertegenwoordigd door de bedrijfsklasse Textielveredeling (SBI 1730), die slechts ongeveer 3.000 werkenden telt. Vanwege dit relatief kleine aantal werkenden zijn er geen gegevens beschikbaar over opleiding, beroep en leeftijd van de werkenden in deze branche.

Tabel 3.21

De textielveredelingsbranche naar opleiding, beroep en leeftijd

\begin{tabular}{lc}
\hline Kenmerk & $\%$ \\
\hline opleiding & - \\
- & \\
beroep & - \\
- & \\
- & leeftijd
\end{tabular}

\section{Bron: CBS/ ROA}

Tabel 3.22 geeft de overige kenmerken van werkenden in de textielveredelingsbranche weer. Het aandeel mannelijke werkenden, het aandeel werkenden in vast dienstverband en in voltijdse werkweek is hoger dan gemiddeld (zie tabel C.4). Daarentegen is het aandeel werkenden van Nederlandse afkomst lager dan gemiddeld. 


\section{Weverij en tapijtknoperij}

De branche van de weverij en tapijtknoperij is onderdeel van twee bedrijfsklassen, namelijk Vervaardiging van vloerkleden en tapijt (SBI 1751) en Weven van textiel (SBI 172). De eerste bedrijfsklasse telt ongeveer 3.000 werkenden, terwijl de tweede bedrijfsklasse ongeveer 4.000 werkenden telt.Tabel 3.23 geeft een indicatie van de leeftijdsopbouw in de branche van de weverij en tapijtknoperij. Ongeveer de helft van de werkenden in deze branche is van middelbare leeftijd.

Tabel 3.22

Overige kenmerken van werkenden in de textielveredelingsbranche

\begin{tabular}{lc}
\hline Kenmerk & $\%$ \\
\hline geslacht & 83 \\
man & 17 \\
vrouw & \\
etniciteit & 83 \\
Nederlands & - \\
allochtoon & - \\
overige buitenlanders & 100 \\
positie werkkring & - \\
vast ( $\geq 1$ jr.) & - \\
flexibel (<1 jr.) & \\
zelfstandig & 100 \\
lengte werkweek & 0 \\
voltijd (>32 uur) & \\
deeltijd ( $\leq 32$ uur) & \\
\hline
\end{tabular}

Bron: CBS/ ROA

Tabel 3.23

De weverij en tapijtknoperij naar opleiding, beroep en leeftijd

\begin{tabular}{lc} 
Kenmerk & $\%$ \\
\hline opleiding & - \\
- & \\
beroep & - \\
- & \\
leeftijd & - \\
jonger (15-29 jr.) & \\
middelbaar $(30-49$ jr. $)$ & 50 \\
ouder (50-64 jr.) & - \\
\hline
\end{tabular}

Bron: CBS/ ROA

Tabel 3.24 geeft de overige kenmerken van de werkenden in de weverij en tapijtknoperij weer. Het aandeel mannen en het aandeel werkenden met een vast contract of het aandeel voltijds werkenden in de weverij en tapijtknoperij is hoger ten 
opzichte van zowel andere ambachtelijke branches als de gehele beroepsbevolking (zie tabel C.4). Het aandeel werkenden van Nederlandse afkomst lijkt in de weverij en tapijtknoperij iets lager te zijn dan in de totale beroepsbevolking.

Tabel 3.24

Overige kenmerken van werkenden in de weverij en tapijtknoperij

\begin{tabular}{|c|c|}
\hline Kenmerk & $\%$ \\
\hline \multicolumn{2}{|l|}{ geslacht } \\
\hline $\begin{array}{l}\text { man } \\
\text { vrouw }\end{array}$ & $\begin{array}{l}79 \\
21\end{array}$ \\
\hline \multicolumn{2}{|l|}{ etniciteit } \\
\hline Nederlands & 86 \\
\hline allochtoon & - \\
\hline overige buitenlanders & - \\
\hline \multicolumn{2}{|l|}{ positie werkkring } \\
\hline vast ( 21 jr.) & 93 \\
\hline $\begin{array}{l}\text { flexibel }(<1 \mathrm{jr} \text { r) } \\
\text { zelfstandig }\end{array}$ & - \\
\hline \multicolumn{2}{|l|}{ lengte werkweek } \\
\hline voltijd (>32 uur) & 86 \\
\hline deeltijd ( $\leq 32$ uur) & 14 \\
\hline
\end{tabular}

Bron: CBS/ROA

\section{Zakkenstopbranche}

De zakkenstopbranche valt onder twee bedrijfsklassen, namelijk Vervaardiging van textielwaren, excl. kleding (SBI 1740) en Reparatie t.b.v. particulieren n.e.g. (SBI 5274). Vrijwel alle 5.500 werkenden in deze twee bedrijfsklassen werken in de eerstgenoemde bedrijfsklasse. De economische activiteit in deze bedrijfsklasse omvat echter veel meer dan alleen zakkenstoppen, zoals bijvoorbeeld de vervaardiging van dekens, vlaggen, stof- en vaatdoeken en parachutes. De gepresenteerde gegevens in tabellen 3.25 en 3.26 hebben derhalve niet alleen betrekking op werkenden in het zakkenstopbedrijf. Tabel 3.25 geeft een indicatie van het beroep en de leeftijdsopbouw van werkenden in de zakkenstopbranche. Het beroep van zakkenmaakster (-stikster) of kleermaker en naaister komt waarschijnlijk het meest voor onder de werkenden in de zakkenstopbranche. Voorts laat de tabel zien dat er waarschijnlijk relatief veel jongeren werken in deze branche.

De overige kenmerken van werkenden in de zakkenstopbranche worden weergegeven in tabel 3.26. Het aandeel mannen in de branche komt overeen met het aandeel mannen in het totaal van ambachtelijke branches, maar is lager dan in de totale beroepsbevolking (zie bijlage $\mathrm{C}$ ). Het aandeel werkenden van Nederlandse afkomst in de zakkenstopbranche komt overeen met de gemiddeldes in de ambachtelijke branches en in de totale beroepsbevolking. Het aandeel werkenden met een vast contract en een 
voltijdse werkweek is in de zakkenstopbranche hoger dan in het totaal van ambachtelijke branches.

Tabel 3.25

De zakkenstopbranche naar opleiding, beroep en leeftijd

\begin{tabular}{lc}
\hline Kenmerk & $\%$ \\
\hline opleiding & - \\
- & \\
beroep & 45 \\
zakkenmaakster, -stikster confectie/ kleermaker, naaister & 55 \\
overige beroepen & \\
leeftijd & 45 \\
jonger (15-29 jr.) & 55 \\
middelbaar (30-49 jr.) & 0 \\
ouder (50-64 jr.) & \\
\hline Bron: CBS/ROA & \\
\hline
\end{tabular}

Bron: CBS/ROA

Tabel 3.26

Overige kenmerken van werkenden in de zakkenstopbranche

\begin{tabular}{|c|c|}
\hline Kenmerk & $\%$ \\
\hline \multicolumn{2}{|l|}{ geslacht } \\
\hline man & 55 \\
\hline vrouw & 45 \\
\hline \multicolumn{2}{|l|}{ etniciteit } \\
\hline Nederlands & 91 \\
\hline allochtoon & - \\
\hline overige buitenlanders & - \\
\hline \multicolumn{2}{|l|}{ positie werkkring } \\
\hline vast $(21 \mathrm{jr}$.) & 82 \\
\hline flexibel (<1 jr.) & - \\
\hline zelfstandig & - \\
\hline \multicolumn{2}{|l|}{ lengte werkweek } \\
\hline voltijd (>32 uur) & 91 \\
\hline deeltijd ( $\leq 32$ uur) & 9 \\
\hline
\end{tabular}

Bron: $\mathrm{CBS} / \mathrm{ROA}$ 


\section{Arbeidsmarktperspectieven voor de ambachten}

In dit hoofdstuk worden de arbeidsmarktperspectieven weergegeven voor opleidingen en beroepen die gerelateerd zijn aan de ambachten. De belangrijkste opleidingen en beroepen voor de ambachten zijn gepresenteerd in de voorafgaande twee hoofdstukken. In dit hoofdstuk wordt gekeken naar indicatoren die een beeld geven van de groei van het aantal werkenden en de baanopeningen van de ambachtelijke beroepen. Verder worden de baanopeningen en de arbeidsmarktperspectieven voor de ambachtelijke opleidingen behandeld.

Het aantal baanopeningen voor nieuwkomers op de arbeidsmarkt bestaat uit twee componenten. De eerste component is de vervangingsvraag, die ontstaat door bijvoorbeeld pensioenering of arbeidsongeschiktheid van werkenden. De tweede component is de uitbreidingsvraag, die ontstaat door een groeiende (positieve uitbreidingsvraag) of krimpende (negatieve uitbreidingsvraag) vraag $^{39}$.

Voor de belangrijkste opleidingen van elk ambacht (zie hoofdstuk 3) wordt gekeken naar het aantal instromers (schoolverlaters) op de arbeidsmarkt en het aantal baanopeningen. Zowel de instroom van nieuwkomers op de arbeidsmarkt als het aantal baanopeningen bepalen het arbeidsmarktperspectief van een opleiding. Het arbeidsmarktperspectief geeft derhalve de verhouding aan tussen vraag en aanbod van schoolverlaters voor een opleiding in de periode 1995-2000. Bij een slecht arbeidsmarktperspectief van een opleiding is er de komende jaren veel meer aanbod van nieuwkomers dan dat er baanopeningen zijn. Dit kan leiden tot een grotere werkloosheid, maar ook tot een verslechtering van de arbeidsmarktpositie waaronder een lagere beloning en meer tijdelijke contracten.

De verhouding tussen het aantal instromers op de arbeidsmarkt en het aantal baanopeningen bepaalt de Indicator Toekomstige Arbeidsmarktsituatie (ITA $)^{40}$. Hoe hoger deze indicator, hoe slechter het toekomstig arbeidsmarktperspectief van een opleiding. Een waarde van ongeveer één duidt op een evenwichtige situatie (zie Borghans et al., 1995). Bij 1,00 of lager wordt de ITA als goed getypeerd, van 1,01 tot en met 1,05 als redelijk, van 1,06 tot en met 1,15 als matig en boven 1,15 als slecht. In hoofdstuk 1 zijn de grenswaarden van alle indicatoren (baanopeningen, uitbreidingsvraag en vervangingsvraag) weergegeven bij de uitleg van de begrippen. Voor elk van de indica-

39. De baanopeningen geeft de som van de uitbreidingsvraag en de vervangingsvraag weer. Als de uitbreidingsvraag negatief is, wordt hiermee rekening gehouden bij de berekening van de vervangingsvraag. Bij een negatieve uitbreidingsvraag is het aantal baanopeningen derhalve gelijk aan de vervangingsvraag. Zie ook hoofdstuk 1 voor een verklaring van de begrippen die gebruikt worden.

40. Bij het berekenen van deze indicator wordt ook rekening gehouden met het aantal kortdurende werklozen en de substitutievraag (zie hoofdstuk 1). 
toren wordt per ambacht het gemiddelde berekend over de beroepen en opleidingen van het betreffende ambacht. De wegingsfactoren zijn de beroeps- of opleidingsaandelen uit hoofdstuk 3 (de categorie overige beroepen of opleidingen wordt hierbij uitgesloten). Als deze aandelen niet bekend zijn, ontbreekt het gemiddelde in de tabel. Als er één opleiding of beroep voor een ambacht opgenomen is, representeren de indicatoren voor de betreffende opleiding of het betreffende beroep het gemiddelde.

De gegevens uit dit hoofdstuk zijn afkomstig van het Informatiesysteem Onderwijs Arbeidsmarkt. De hoofdlijnen van deze prognose studie zijn gepubliceerd in $D e$ Arbeidsmarkt naar Opleiding en Beroep (ROA, 1995, 1996).

\section{Banketbakkersbranche}

Uit het voorgaande hoofdstuk is gebleken dat $40 \%$ van de werkenden in de banketbakkersbranche als brood- en banketbakker werkt. Onder de overige werkenden in de banketbakkersbranche is relatief veel verkooppersoneel (27\%). De trend tussen 1991 en 1995 voor de beroepsklasse van bakkers en chocolademakers is dalend, hetgeen in een negatieve uitbreidingsvraag resulteert. Tabel 4.1 laat de uitbreidingsvraag, vervangingsvraag en het totale aantal baanopeningen zien voor de banketbakkersbranche. Uit de tabel blijkt dat de vervangingssvraag voor bakkers en chocolademakers als laag getypeerd kan worden. De instroom van nieuwkomers die als bakker of chocolademaker willen gaan werken in de brood- en banketbakkersbranche wordt derhalve beperkt door de lage vervangings- en uitbreidingsvraag. Daarentegen zijn voor het verkooppersoneel in de banketbakkersbranche de uitbreidingsvraag hoog en de vervangingsvraag gemiddeld. Dit resulteert in een hoog percentage baanopeningen voor het verkooppersoneel. Het verwachte gemiddelde percentage baanopeningen van beroepen in het banketbakkersbedrijf is gemiddeld $(23 \%)^{41}$.

Tabel 4.1

Baanopeningen van beroepen van de banketbakkersbranche, uitgesplitst naar uitbreidings- en vervangingsvraag, $1995-2000$

\begin{tabular}{lccc}
\hline Beroep & $\begin{array}{c}\text { Uitbreidingsvraag } \\
\%\end{array}$ & $\begin{array}{c}\text { Vervangingsvraag } \\
\%\end{array}$ & $\begin{array}{c}\text { Baanopeningen } \\
\%\end{array}$ \\
\hline bakkers en chocolademakers & -5 & 15 & 15 \\
verkooppersoneel & 16 & 18 & 34 \\
gewogen gemiddelde & 3 & 16 & 23 \\
\hline
\end{tabular}

Bron: ROA

Opm.: Zie paragraaf 4.1 en hoofdstuk 1 voor de uitleg van de gebruikte begrippen en hun onderlinge samenhang. Hoofdstuk 1 geeft ook de grenswaarden van de kwalitatieve typeringen weer (laag, hoog, gemiddeld, e.d.).

41. De wegingsfactoren zijn de beroepsaandelen in de banketbakkersbranche uit tabel 3.1 , waarbij de categorieën lager technisch personeel en overige beroepen niet worden meegerekend. 
Tabel 4.2 geeft de verwachting weer voor de periode van 1995 tot 2000 van de verwachte vervangingsvraag, uitbreidingsvraag en baanopeningen van opleidingen die in de banketbakkersbranche het meest voorkomen (zie hiervoor tabel 3.1). Verder presenteert de tabel de gewogen gemiddeldes van elk van deze gegevens voor de banketbakkersbranche ${ }^{42}$. Met uitzondering van de twee MBO-opleidingen hebben alle opleidingen in de tabel een negatieve uitbreidingsvraag. Omdat voor de bepaling van de vervangingsvraag rekening wordt gehouden met een negatieve uitbreidingsvraag, is voor deze opleidingen de vervangingsvraag gelijk aan de baanopeningen. Uit de tabel blijkt dat de twee opleidingen die (onder andere) opleiden voor het bakkersberoep, MBO/LLW Consumptieve Techniek en VBO Consumptieve Techniek als gevolg van een tegengestelde ontwikkeling in de uitbreidingsvraag sterk verschillen in het percentage baanopeningen. Voor het $M B O / L L W$ Consumptieve Techniek is de uitbreidingsvraag positief, maar voor het VBO Consumptieve Techniek is deze negatief. Behalve voor de opleiding MBO/LLW Consumptieve Techniek is het percentage baanopeningen ook gemiddeld voor MBO/LLW Administratief en VBO Verzorging. Daarentegen heeft de opleiding VBO Consumptieve Techniek een erg laag percentage baanopeningen.

Tabel 4.2

Baanopeningen van opleidingen voor de banketbakkersbranche, uitgesplitst naar uitbreidings- en vervangingsvraag, 1995-2000

\begin{tabular}{lccc}
\hline Opleiding & $\begin{array}{c}\text { Uitbreidingsvraag } \\
\%\end{array}$ & $\begin{array}{c}\text { Vervangingsvraag } \\
\%\end{array}$ & $\begin{array}{c}\text { Baanopeningen } \\
\%\end{array}$ \\
\hline MBO/LLW Consumptieve Techniek & 5 & 14 & 19 \\
VBO Consumptieve Techniek & -4 & 9 & 9 \\
Basisonderwijs & -13 & 14 & 14 \\
MBO/LLW Administratief & 3 & 19 & 18 \\
VBO Verzorging & -3 & 14 & 14 \\
MAVO, onderbouw HAVO/NWO & -5 & 14 & 16 \\
gewogen gemiddelde & -2 & & \\
\hline
\end{tabular}

\section{Bron: ROA}

Opm.: Zie paragraaf 4.1 en hoofdstuk 1 voor de uitleg van de gebruikte begrippen en hun onderlinge samenhang. Hoofdstuk 1 geeft ook de grenswaarden van de kwalitatieve typeringen weer (laag, hoog, gemiddeld, e.d.).

Uit tabel 4.2 blijkt verder dat de opleiding MBO/LLW Consumptieve Techniek, die bestemd is voor het beroep van bakker en chocolademaker, een hoger percentage baanopeningen heeft dan het beroep van bakkers en chocolademakers in tabel 4.1. De opleiding VBO Consumptieve Techniek heeft daarentegen minder baanopeningen dan het beroep van bakkers en chocolademakers. De uitwijkmogelijkheden voor deze twee opleidingen zijn gemiddeld. Een aanzienlijk deel van de werkenden met een opleiding

42. De wegingsfactoren zijn de opleidingsaandelen in de banketbakkersbranche uit tabel 3.1, waarbij de categorie overige opleidingen niet wordt meegerekend. 
MBO/LLW Consumptieve Techniek (ongeveer een kwart) werkt als winkelier, handelaar, ondernemer, inkoper, etc. Een ander deel (een vijfde) werkt als voedings- en genotmiddelenbereider. Van de werkenden met een opleiding VBO Consumptieve Techniek is een significant gedeelte $(14 \%)$ werkzaam als keuken- en serveerpersoneel. Voor werkenden met één van de overige opleidingen, die relatief vaak terecht komen als verkoper in het banketbakkersbedrijf, zijn de uitwijkmogelijkheden in het algemeen hoog. De beroepen waarin deze werkenden terecht zijn heel divers: van schoonmaakpersoneel tot bankemployés.

Tabel 4.3 geeft de verwachte instroom, baanopeningen en arbeidsmarktperspectieven (ITA) weer. Uit de tabel blijkt dat de twee opleidingen die opleiden voor het bakkersberoep, MBO/LLW Consumptieve Techniek en VBO Consumptieve Techniek, matige $(1,06)$ respectievelijk slechte $(1,29)$ perspectieven hebben ${ }^{43}$. Voor de eerstgenoemde opleiding stijgen zowel de instroom als de baanopeningen met $19 \%$ over 5 jaar, terwijl voor de laatstgenoemde opleiding de instroom veel groter is dan de baanopeningen ( $26 \%$ versus $9 \%$ ). De werkenden die één van de overige opleidingen als opleidingsachtergrond hebben, zijn veelal in de verkoop werkzaam. Alleen de werkenden met een opleiding VBO Verzorging of MAVO, onderbouw HAVONWO hebben een beter arbeidsmarktperspectief.

De verwachte instroom van de opleidingen voor de banketbakkersbranche is $17 \%$, terwijl het verwachte aantal baanopeningen van de betreffende opleidingen slechts $16 \%$ van het totale aantal banen is. De ITA geeft dan ook een matig arbeidsmarktperspectief aan van 1,10 .

Tabel 4.3

Arbeidsmarktperspectieven van opleidingen voor de banketbakkersbranche, 1995-2000

\begin{tabular}{lrcc}
\hline Opleiding & $\begin{array}{c}\text { Instroom } \\
\%\end{array}$ & $\begin{array}{c}\text { Baanopeningen } \\
\%\end{array}$ & ITA \\
\hline MBO/LLW Consumptieve Techniek & 19 & 19 & 1,06 \\
VBO Consumptieve Techniek & 26 & 9 & 1,29 \\
Basisonderwijs & 9 & 14 & 1,08 \\
MBO/LLW Administratief & 29 & 18 & 1,12 \\
VBO Verzorging & 7 & 19 & 0,99 \\
MAVO, onderbouw HAVONWO & 6 & 14 & 1,01 \\
gewogen gemiddelde & 17 & 16 & 1,10
\end{tabular}

Bron: ROA

Opm.: Zie paragraaf 4.1 en hoofdstuk 1 voor de uitleg van de gebruikte begrippen en hun onderlinge samenhang. Hoofdstuk 1 geeft ook de grenswaarden van de kwalitatieve typeringen weer (laag, hoog, gemiddeld, e.d.).

43. Zie paragraaf 4.1 en hoofdstuk 1 voor een verklaring van de gebruikte begrippen. 


\section{Dakdekkersbranche}

Het beroep van dakdekker valt in de ROA-prognoses onder een bredere beroepsklasse waartoe ook betonwerkers, isoleerders en glaszetters behoren. De trend van het aantal werkenden in deze beroepsklasse over 1991 tot 1995 is constant. Tabel 4.4 laat de verwachte uitbreidingsvraag, vervangingsvraag en baanopeningen zien voor het beroep van dakdekker ${ }^{44}$. Zowel de uitbreidings- en vervangingsvraag als de baanopeningen zijn laag.

Tabel 4.4

Baanopeningen van beroepen van de dakdekkersbranche, uitgesplitst naar uitbreidings- en vervangingsvraag, $1995-2000$

\begin{tabular}{lccc}
\hline Beroep & $\begin{array}{c}\text { Uitbreidingsvraag } \\
\%\end{array}$ & $\begin{array}{c}\text { Vervangingsvraag } \\
\%\end{array}$ & $\begin{array}{c}\text { Baanopeningen } \\
\%\end{array}$ \\
\hline dakdekkers & -9 & 17 & 17 \\
\hline
\end{tabular}

Bron: ROA

Opm.: Zie paragraaf 4.1 en hoofdstuk 1 voor de uitleg van de gebruikte begrippen en hun onderlinge samenhang.

Tabel 4.5

Baanopeningen van opleidingen voor de dakdekkersbranche, uitgesplitst naar uitbreidings- en vervangingsvraag, $1995-2000$

\begin{tabular}{lccc}
\hline Opleiding & $\begin{array}{c}\text { Uitbreidingsvraag } \\
\%\end{array}$ & $\begin{array}{c}\text { Vervangingsvraag } \\
\%\end{array}$ & $\begin{array}{c}\text { Baanopeningen } \\
\%\end{array}$ \\
\hline VBO Techniek & -5 & 14 & 14 \\
\hline
\end{tabular}

Bron: ROA

Opm.: Zie paragraaf 4.1 en hoofdstuk 1 voor de uitleg van de gebruikte begrippen en hun onderlinge samenhang. Hoofdstuk $1 \mathrm{geeft}$ ook de grenswaarden van de kwalitatieve typeringen weer (laag, hoog, gemiddeld, e.d.).

Tabel 4.5 geeft de uitbreidingsvraag, vervangingsvraag en baanopeningen weer voor de belangrijkste opleiding in de dakdekkersbranche, namelijk VBO Techniek. Uit hoofdstuk 3 is gebleken dat $28 \%$ van de werkenden in de dakdekkersbranche VBO Techniek als opleidingsachtergrond heeft ${ }^{45}$. De uitbreidingsvraag, vervangingsvraag en baanopeningen voor deze opleiding zijn laag. Uit een vergelijking tussen beroep en opleiding blijkt dat de vraag naar dakdekkers sneller daalt dan de vraag naar opgeleiden met

44. De gebruikte gegevens van het Centraal Bureau voor de Statistiek laten geen nadere specificatie van het beroep van dakdekker toe, zoals aankomend dakdekker, voorman, $1 \mathrm{e}$ dakdekker, etc.

45. Het aandeel werkenden in de dakdekkersbranche dat een opleiding tot dakdekker in het primaire leerlingwezen heeft afgesloten, kan vanwege de restricties die het Centraal Bureau voor de Statistiek oplegd niet achterhaald worden. 
VBO Techniek als opleidingsachtergrond, maar dat anderzijds het beroep dakdekkers meer vervangingsvraag kent. De uitwijkmogelijkheden voor werkenden met een opleiding VBO (Bouw)Techniek zijn gemiddeld, maar divers: van timmerlieden tot buizenleggers.

Tabel 4.6 geeft de arbeidsmarktperspectieven voor VBO Techniek weer. De Indicator Toekomstige Arbeidsmarktsituatie (ITA) geeft een matig arbeidsmarktperspectief aan, hetgeen de ongunstige verhouding tussen instroom en baanopeningen weerspiegelt.

Tabel 4.6

Arbeidsmarktperspectieven van opleidingen van de dakdekkersbranche, 1995-2000

\begin{tabular}{lccc}
\hline Opleiding & $\begin{array}{c}\text { Instroom } \\
\%\end{array}$ & $\begin{array}{c}\text { Baanopeningen } \\
\%\end{array}$ & ITA \\
\hline VBO Techniek & 6 & 14 & 1,10 \\
\hline
\end{tabular}

Bron: ROA

Opm.: Zie paragraaf 4.1 en hoofdstuk 1 voor de uitleg van de gebruikte begrippen en hun onderlinge samenhang. Hoofdstuk $1 \mathrm{geeft}$ ook de grenswaarden van de kwalitatieve typeringen weer (laag, hoog, gemiddeld, e.d.).

\section{Glazenwassers- en schoonmaakbranche}

In de prognoses van het ROA vallen de glazenwassers onder de beroepsklasse van de schoonmakers ${ }^{46}$. Tabel 4.7 geeft de verwachte ontwikkeling tot en met het jaar 2000 van schoonmakers weer. De glazenwassers- en schoonmaakbranche kenmerkt zich door een negatieve uitbreidingsvraag. Voor schoolverlaters betekent dit dat zij alleen vrijkomende banen van vertrekkende schoonmakers kunnen innemen, voor deze opnieuw worden ingevuld. Het percentage baanopeningen in deze beroepsklasse $(21 \%)$ kan als gemiddeld worden getypeerd.

Tabel 4.7

Baanopeningen van beroepen van de glazenwassers- en schoonmaakbranche, uitgesplitst naar uitbreidings- en vervangingsvraag, 1995-2000

\begin{tabular}{lccc}
\hline Beroep & $\begin{array}{c}\text { Uitbreidingsvraag } \\
\%\end{array}$ & $\begin{array}{c}\text { Vervangingsvraag } \\
\%\end{array}$ & $\begin{array}{c}\text { Baanopeningen } \\
\%\end{array}$ \\
\hline schoonmaakpersoneel & -11 & 21 & 21 \\
\hline
\end{tabular}

Bron: ROA

Opm.: Zie paragraaf 4.1 en hoofdstuk 1 voor de uitleg van de gebruikte begrippen en hun onderlinge samenhang. Hoofdstuk $1 \mathrm{geeft}$ ook de grenswaarden van de kwalitatieve typeringen weer (laag, hoog, gemiddeld, e.d.).

46. In de CBS-classificaties zijn de glazenwassers nauwelijks te onderscheiden van het overige schoonmaakpersoneel (zie ook paragraaf 3.10). Er zijn echter goede gronden om aan te nemen dat de ontwikkelingen in de glazenwassers- en schoonmaakbranche dezelfde zijn. 
Tabel 4.8 presenteert voor diverse opleidingen die veel in de glazenwassers- en schoonmaakbranche voorkomen (zie tabel 3.7) de uitbreidingsvraag, vervangingsvraag en baanopeningen. Voor de meeste opleidingen is de uitbreidingsvraag negatief. De vervangingsvraag is alleen hoog voor VBO Verzorging en gemiddeld voor de overige opleidingen. Het percentage baanopeningen is gemiddeld voor VBO Verzorging, MBO/LLW Administratief en MBO/LLW Verzorgend, terwijl het percentage baanopeningen laag is voor de overige opleidingen in de tabel. Het gemiddelde percentage baanopeningen voor opleidingen in de glazenwassers- en schoonmaakbranche ligt lager dan het gemiddelde van de beroepsklassen van schoonmakers in tabel 4.6. De uitwijkmogelijkheden kunnen daarom belangrijk zijn. Deze zijn vooral hoog voor de drie eerstegenoemde opleidingen in de tabellen. Werkenden met een dergelijke opleidingsachtergrond komen vooral terecht in de beroepen van portiers en schoonmaakpersoneel, verkooppersoneel en keuken- en serveerpersoneel, administrateurs en bankemployés, en commercieel-administratieve employés.

Tabel 4.8

Baanopeningen van opleidingen van de glazenwassers- en schoonmaakbranche, uitgesplitst naar uitbreidings- en vervangingsvraag, 1995-2000

\begin{tabular}{lccc}
\hline Opleiding & $\begin{array}{c}\text { Uitbreidingsvraag } \\
\%\end{array}$ & $\begin{array}{c}\text { Vervangingsvraag } \\
\%\end{array}$ & $\begin{array}{c}\text { Baanopeningen } \\
\%\end{array}$ \\
& -13 & 14 & 14 \\
Basisonderwijs & -3 & 19 & 19 \\
VBO Verzorging & -5 & 14 & 14 \\
MAVO, onderbouw HAVO/NWO & -5 & 14 & 14 \\
VBO Techniek & 3 & 15 & 18 \\
MBO/LLW Administratief & 4 & 14 & 18 \\
MBO/ LLW Verzorgend & -6 & 15 & 16 \\
gewogen gemiddelde & & &
\end{tabular}

\section{Bron: ROA}

Opm.: Zie paragraaf 4.1 en hoofdstuk 1 voor de uitleg van de gebruikte begrippen en hun onderlinge samenhang. Hoofdstuk 1 geeft ook de grenswaarden van de kwalitatieve typeringen weer (laag, hoog, gemiddeld, e.d.).

Tabel 4.9 presenteert de arbeidsmarktperspectieven van opleidingen in de glazenwassers- en schoonmaakbranche, waardoor de instroom met de baanopeningen van opleidingen vergeleken kan worden. Voor de opleidingen MBO/ LLW Administratief en $M B O / L L W$ Verzorgend is de verhouding hiertussen ongunstig, hetgeen resulteert in een matig arbeidsmarktperspectief. Van de overige opleidingen heeft alleen de opleiding VBO Verzorging een goed arbeidsmarktperspectief, terwijl de opleiding MAVO, onderbouw HAVO/ VWO een redelijk arbeidsmarktperspectief heeft. Het gemiddelde arbeidsmarktperspectief van opleidingen van de glazenwassers- en schoonmaakbranche is matig $(1,14)$. In hoofdstuk 3 werd duidelijk dat $32 \%$ van de werkenden in de glazenwassers- en schoonmaakbranche slechts basisonderwijs heeft doorlopen. Aangezien de arbeidsmarktperspectieven matig zijn voor het basisonderwijs en voor de meeste overige opleidingen die werkenden in de glazenwasserbranche als opleidingsachtergrond hebben, zal de glazenwassers- en schoonmaakbranche niet veel moeite 
hebben nieuw personeel aan te trekken.

Tabel 4.9

Arbeidsmarktperspectieven van opleidingen van de glazenwassers- en schoonmaakbranche, $1995-2000$

\begin{tabular}{lccc}
\hline Opleiding & $\begin{array}{c}\text { Instroom } \\
\%\end{array}$ & $\begin{array}{c}\text { Baanopeningen } \\
\%\end{array}$ & ITA \\
\hline Basisonderwijs & 9 & 14 & 1,08 \\
VBO Verzorging & 7 & 19 & 0,99 \\
MAVO, onderbouw HAVO/NWO & 6 & 14 & 1,01 \\
VBO Techniek & 6 & 14 & 1,10 \\
MBO/LLW Administratief & 29 & 18 & 1,12 \\
MBO/ LLW Verzorgend & 29 & 16 & 1,07 \\
& & & 1,14 \\
\hline
\end{tabular}

Bron: ROA

Opm.: Zie paragraaf 4.1 en hoofdstuk 1 voor de uitleg van de gebruikte begrippen en hun onderlinge samenhang. Hoofdstuk 1 geeft ook de grenswaarden van de kwalitatieve typeringen weer (laag, hoog, gemiddeld, e.d.).

\section{Kappersbranche}

Het aantal werkenden in de beroepsklasse waartoe kappers behoren, is constant over de periode van 1991 tot en met 1995. Tabel 4.10 laat de verwachte uitbreidingsvraag, vervangingsvraag en baanopeningen zien voor het kappersberoep voor 1995 tot $2000^{47}$. Uit de tabel blijkt dat de uitbreidingsvraag laag en zelfs negatief is, en dat de vervangingsvraag en baanopeningen eveneens laag zijn.

Tabel 4.10

Baanopeningen van beroepen van de kappersbranche, uitgesplitst naar uitbreidings- en vervangingsvraag, $1995-2000$

\begin{tabular}{lccc}
\hline Beroep & $\begin{array}{c}\text { Uitbreidingsvraag } \\
\%\end{array}$ & $\begin{array}{c}\text { Vervangingsvraag } \\
\%\end{array}$ & $\begin{array}{c}\text { Baanopeningen } \\
\%\end{array}$ \\
\hline kappers & -11 & 14 & 14 \\
\hline
\end{tabular}

Bron: ROA

Opm.: Zie paragraaf 4.1 en hoofdstuk 1 voor de uitleg van de gebruikte begrippen en hun onderlinge samenhang. Hoofdstuk 1 geeft ook de grenswaarden van de kwalitatieve typeringen weer (laag, hoog, gemiddeld, e.d.).

47. In de prognoses van het ROA (1996) vallen de kappers onder dezelfde beroepsklasse als de schoonheidsspecialisten. Daarnaast laten de gebruikte gegevens van het Centraal Bureau voor de Statistiek laten geen nadere specificatie van het beroep van kapper toe, zoals kappershulp. 
Tabel 4.11 laat de uitbreidingsvraag, vervangingsvraag en baanopeningen zien voor de kappersbranche. In het algemeen kunnen de gepresenteerde percentages als gemiddeld worden getypeerd. De baanopeningen voor de kappersopleidingen zijn niet veel groter dan de baanopeningen voor het beroep van kapper (zie tabel 4.10). Uit de voorgaande twee hoofdstukken is gebleken dat de er een goede aansluiting is tussen de opleidingen en het beroep van kappers. Daarnaast zijn de uitwijkmogelijkheden voor de twee genoemde opleidingen in tabel 4.12 gemiddeld. Andere relatief veel voorkomende beroepen voor deze opleidingen zijn schoonheidsspecialisten, kinder-, gezins- en bejaardenverzorgenden, en keuken- en serveerpersoneel.

Tabel 4.11

Baanopeningen van opleidingen van de kappersbranche, uitgesplitst naar uitbreidings- en vervangingsvraag, $1995-2000$

\begin{tabular}{lccc}
\hline Opleiding & $\begin{array}{c}\text { Uitbreidingsvraag } \\
\%\end{array}$ & $\begin{array}{c}\text { Vervangingsvraag } \\
\%\end{array}$ & $\begin{array}{c}\text { Baanopeningen } \\
\%\end{array}$ \\
\hline MBO/LLW Verzorging & 4 & 14 & 18 \\
MBO/ LLW Uiterlijke Verzorging & 3 & 13 & 16 \\
gewogen gemiddelde & 4 & 14 & 17
\end{tabular}

Bron: ROA

Opm.: Zie paragraaf 4.1 en hoofdstuk 1 voor de uitleg van de gebruikte begrippen en hun onderlinge samenhang. Hoofdstuk $1 \mathrm{geeft}$ ook de grenswaarden van de kwalitatieve typeringen weer (laag, hoog, gemiddeld, e.d.).

Tabel 4.12 presenteert de instroom, baanopeningen en arbeidsmarktperspectieven van opleidingen van de kappersbranche. Uit de tabel blijkt dat de verhouding tussen instroom en baanopeningen niet gunstig is, hetgeen resulteert in een matig arbeidsmarktperspectief voor de opleidingen van de kappersbranche.

Tabel 4.12

Arbeidsmarktperspectieven van opleidingen van de kappersbranche, 1995-2000

\begin{tabular}{lccc}
\hline Opleiding & $\begin{array}{c}\text { Instroom } \\
\%\end{array}$ & $\begin{array}{c}\text { Baanopeningen } \\
\%\end{array}$ & ITA \\
\hline MBO/LLW Verzorging & 29 & 18 & 1,14 \\
MBO/ LLW Uiterlijke Verzorging & 14 & 16 & 1,07 \\
gewogen gemiddelde & 24 & 17 & 1,12 \\
\hline
\end{tabular}

Bron: ROA

Opm.: Zie paragraaf 4.1 en hoofdstuk 1 voor de uitleg van de gebruikte begrippen en hun onderlinge samenhang. Hoofdstuk $1 \mathrm{geeft}$ ook de grenswaarden van de kwalitatieve typeringen weer (laag, hoog, gemiddeld, e.d.).

\section{Optiekbranche}

De trend van het aantal werkenden in het beroep van opticien is stijgend over 1991 tot 
en met $1995^{48}$. De verwachte uitbreidingsvraag, vervangingsvraag en baanopeningen van 1995 tot 2000 zijn in tabel 4.13 weergegeven. Deze verwachte procentuele toenames van het aantal banen kunnen als gemiddeld getypeerd worden.

Tabel 4.13

Baanopeningen van beroepen van de optiekbranche, uitgesplitst naar uitbreidings- en vervangingsvraag, $1995-2000$

\begin{tabular}{lccc}
\hline Beroep & $\begin{array}{c}\text { Uitbreidingsvraag } \\
\%\end{array}$ & $\begin{array}{c}\text { Vervangingsvraag } \\
\%\end{array}$ & $\begin{array}{c}\text { Baanopeningen } \\
\%\end{array}$ \\
\hline opticiens & 5 & 18 & 24 \\
\hline
\end{tabular}

Bron: ROA

Opm.: Zie paragraaf 4.1 en hoofdstuk 1 voor de uitleg van de gebruikte begrippen en hun onderlinge samenhang. Hoofdstuk 1 geeft ook de grenswaarden van de kwalitatieve typeringen weer (laag, hoog, gemiddeld, e.d.).

Tabel 4.14 laat de uitbreidingsvraag, vervangingsvraag en baanopeningen zien van de belangrijkste opleidingstype, MBO/LLW Medisch laboratorium, in de optiekbranche. Dit opleidingstype omvat onder meer de opleidingen tot (assistent-)opticien. De werkenden in de optiekbranche zullen waarschijnlijk allen een specialisatie in optiekrichting hebben afgerond ${ }^{49}$. De verwachte procentuele toenames van de uitbreidings- en vervangingsvraag en de baanopeningen zijn als gemiddeld te typeren. Het aantal baanopeningen voor de opleiding MBO/LLW Medisch laboratorium is iets groter dan het aantal baanopeningen voor het beroep van opticien. De uitwijkmogelijkheden voor de opleiding MBO/LLW Medisch laboratorium zijn daarbij laag. Een aanzienlijk gedeelte van werkenden met deze opleidingsachtergrond werkt als apothekersassistente, analist en laborant.

Tabel 4.14

Baanopeningen van opleidingen van de optiekbranche, uitgesplitst naar uitbreidings- en vervangingsvraag, $1995-2000$

\begin{tabular}{lccc}
\hline Opleiding & $\begin{array}{c}\text { Uitbreidingsvraag } \\
\%\end{array}$ & $\begin{array}{c}\text { Vervangingsvraag } \\
\%\end{array}$ & $\begin{array}{c}\text { Baanopeningen } \\
\%\end{array}$ \\
\hline $\begin{array}{l}\text { MBO/LLW Medisch } \\
\text { laboratorium/optiek }\end{array}$ & 10 & 15 & 26 \\
\hline
\end{tabular}

Bron: ROA

Opm.: Zie paragraaf 4.1 en hoofdstuk 1 voor de uitleg van de gebruikte begrippen en hun onderlinge samenhang. Hoofdstuk 1 geeft ook de grenswaarden van de kwalitatieve typeringen weer (laag, hoog, gemiddeld, e.d.).

48. Op basis van de gebruikte gegevens van het Centraal Bureau voor de Statistiek kan geen nadere specificatie van het beroep van opticien worden gegeven, zoals bijvoorbeeld assistentopticien.

49. Dit is echter door de restricties die het CBS oplegt bij het gebruik van hun data niet na te gaan. 
Tabel 4.15 geeft het arbeidsmarktperspectief van de opleiding MBO/LLW Medisch laboratorium weer. Door de gunstige verhouding tussen instroom en baanopeningen is dit perspectief goed. Dit betekent voor de werkgevers in de optiekbranche dat er een knelpunt in de werving van geschikt personeel kan optreden.

Tabel 4.15

Arbeidsmarktperspectieven van opleidingen van de optiekbranche, 1995-2000

\begin{tabular}{|c|c|c|c|}
\hline Opleiding & $\begin{array}{c}\text { Instroom } \\
\%\end{array}$ & $\begin{array}{l}\text { Baanopeningen } \\
\%\end{array}$ & ITA \\
\hline $\begin{array}{l}\text { MBO/LLW Medisch } \\
\text { laboratorium/optiek }\end{array}$ & 13 & 26 & 0,94 \\
\hline
\end{tabular}

\section{Schoonheids- en voetverzorgingsbranche}

Het aantal werkenden in de beroepsklasse waartoe schoonheids- en voetverzorgers behoren, is constant over de periode van 1991 tot en met 1995. Tabel 4.16 laat de verwachte uitbreidingsvraag, vervangingsvraag en baanopeningen zien voor het beroep van de schoonheids- en voetverzorgers voor 1995 tot $2000^{50}$. Uit de tabel blijkt dat de uitbreidingsvraag laag en zelfs negatief is, en dat de vervangingsvraag en baanopeningen eveneens laag zijn.

Tabel 4.16

Baanopeningen van beroepen van de schoonheids- en voetverzorgingsbranche, uitgesplitst naar uitbreidings- en vervangingsvraag, 1995-2000

\begin{tabular}{lccc}
\hline Beroep & $\begin{array}{c}\text { Uitbreidingsvraag } \\
\%\end{array}$ & $\begin{array}{c}\text { Vervangingsvraag } \\
\%\end{array}$ & $\begin{array}{c}\text { Baanopeningen } \\
\%\end{array}$ \\
\hline $\begin{array}{l}\text { schoonheids- en } \\
\text { voetverzorgers }\end{array}$ & -11 & 14 & 14 \\
\hline
\end{tabular}

Bron: ROA

Opm.: Zie paragraaf 4.1 en hoofdstuk 1 voor de uitleg van de gebruikte begrippen en hun onderlinge samenhang. Hoofdstuk $1 \mathrm{geeft}$ ook de grenswaarden van de kwalitatieve typeringen weer (laag, hoog, gemiddeld, e.d.).

Tabel 4.17 laat de uitbreidingsvraag, vervangingsvraag en baanopeningen zien voor de schoonheids- en voetverzorgingsbranche. In het algemeen kunnen de gepresenteerde percentages als gemiddeld worden getypeerd (zie ook hoofdstuk 1 bij de uitleg van de begrippen). De baanopeningen voor de opleidingen van de schoonheids- en voet-

50. In de prognoses van het ROA (1996) vallen de schoonheids- en voetspecialisten onder dezelfde beroepsklasse als de kappers en de grimeurs (zie bijlage $B$ ). 
verzorgingsbranche zijn niet veel groter dan de baanopeningen voor het beroep van schoonheids- en voetverzorger (zie tabel 4.16). Uit de voorgaande twee hoofdstukken is gebleken dat de er een goede aansluiting is tussen de opleidingen en het beroep van schoonheids- en voetverzorgers. Daarnaast zijn de uitwijkmogelijkheden voor de twee genoemde opleidingen in tabel 4.17 gemiddeld. Andere relatief veel voorkomende beroepen voor deze opleidingen zijn kappers, kinder-, gezins- en bejaardenverzorgenden, en keuken- en serveerpersoneel.

Tabel 4.17

Baanopeningen van opleidingen van de schoonheids- en voetverzorgingsbranche, uitgesplitst naar uitbreidings- en vervangingsvraag, 1995-2000

\begin{tabular}{lccc}
\hline Opleiding & $\begin{array}{c}\text { Uitbreidingsvraag } \\
\%\end{array}$ & $\begin{array}{c}\text { Vervangingsvraag } \\
\%\end{array}$ & $\begin{array}{c}\text { Baanopeningen } \\
\%\end{array}$ \\
\hline MBO/LLW Verzorging & 4 & 14 & 18 \\
MBO/LLW Uiterlijke Verzorging & 3 & 13 & 16 \\
\hline $\begin{array}{l}\text { Bron: ROA } \\
\text { Opm.: Zie paragraaf } 4.1 \text { en hoofdstuk 1 voor de uitleg van de gebruikte begrippen en hun } \\
\text { onderlinge samenhang. Hoofdstuk } 1 \text { geeft ook de grenswaarden van de kwalitatieve typeringen } \\
\text { weer (laag, hoog, gemiddeld, e.d.). }\end{array}$
\end{tabular}

Tabel 4.18 laat de instroom, baanopeningen en arbeidsmarktperspectieven van opleidingen van de schoonheids- en voetverzorgingsbranche zien. Uit de tabel blijkt dat de verhouding tussen instroom en baanopeningen niet gunstig is. Dit resulteert in een matig arbeidsmarktperspectief voor de opleidingen van de schoonheids- en voetverzorgingsbranche.

Tabel 4.18

Arbeidsmarktperspectieven van opleidingen van de schoonheids- en voetverzorgingsbranche, 1995-2000

\begin{tabular}{lccc}
\hline Opleiding & $\begin{array}{c}\text { Instroom } \\
\%\end{array}$ & $\begin{array}{c}\text { Baanopeningen } \\
\%\end{array}$ & ITA \\
\hline MBO/LLW Verzorging & 29 & 18 & 1,14 \\
MBO/LLW Uiterlijke Verzorging & 14 & 16 & 1,07 \\
\hline
\end{tabular}

Bron: ROA

Opm.: Zie paragraaf 4.1 en hoofdstuk 1 voor de uitleg van de gebruikte begrippen en hun onderlinge samenhang. Hoofdstuk 1 geeft ook de grenswaarden van de kwalitatieve typeringen weer (laag, hoog, gemiddeld, e.d.).

\section{Slagersbranche}

De trend over 1991 tot en met 1995 van de beroepsklasse waartoe de slagers behoren 
is dalend ${ }^{51}$. Tabel 4.19 geeft de verwachte uitbreidingsvraag, vervangingsvraag en baanopeningen weer van beroepen die tot de slagersbranche behoren over de periode 1995 tot 2000. De verwachte uitbreidingsvraag voor slagers, die $55 \%$ van de werkenden van de slagersbranche uitmaken (zie tabel 3.17), is laag en negatief. De verwachte uitbreidingsvraag voor het verkooppersoneel, $23 \%$ van de werkenden in de slagersbranche, is daarentegen hoog. Vanwege de hoge vervangingsvraag voor slagers, is het percentage baanopeningen toch nog gemiddeld, namelijk $24 \%$. Het percentage baanopeningen voor verkooppersoneel is hoog. Het gewogen gemiddelde van baanopeningen in de slagersbranche is $27 \%$, hetgeen gemiddeld is.

Tabel 4.19

Baanopeningen van beroepen van de slagersbranche, uitgesplitst naar uitbreidings- en vervangingsvraag, $1995-2000$

\begin{tabular}{lccc}
\hline Beroep & $\begin{array}{c}\text { Uitbreidingsvraag } \\
\%\end{array}$ & $\begin{array}{c}\text { Vervangingsvraag } \\
\%\end{array}$ & $\begin{array}{c}\text { Baanopeningen } \\
\%\end{array}$ \\
\hline slagers & -6 & 24 & 24 \\
verkooppersoneel & 16 & 18 & 34 \\
gewogen gemiddelde & 0 & 22 & 27 \\
\hline
\end{tabular}

Bron: ROA

Opm.: Zie paragraaf 4.1 en hoofdstuk 1 voor de uitleg van de gebruikte begrippen en hun onderlinge samenhang. Hoofdstuk 1 geeft ook de grenswaarden van de kwalitatieve typeringen weer (laag, hoog, gemiddeld, e.d.).

Tabel 4.20 geeft de verwachting weer voor de periode van 1995 tot 2000 van de verwachte vervangingsvraag, uitbreidingsvraag en baanopeningen van opleidingen die in de slagersbranche het meest voorkomen (zie hiervoor tabel 3.17). Verder presenteert de tabel de gewogen gemiddeldes van elk van deze gegevens voor de slagersbranche. Met uitzondering van de twee MBO-opleidingen hebben alle opleidingen in de tabel een negatieve uitbreidingsvraag. Uit de tabel blijkt dat de twee opleidingen die (onder andere) opleiden voor het slagersberoep, MBO/ LLW Consumptieve Techniek en VBO Consumptieve Techniek, als gevolg van een tegengestelde ontwikkeling in de uitbreidingsvraag sterk verschillen in het percentage baanopeningen. Behalve voor de opleiding MBO/ LLW Consumptieve Techniek is het percentage baanopeningen ook gemiddeld voor MBO/ LLW Administratief en VBO Verzorging. Daarentegen heeft de opleiding VBO Consumptieve Techniek een erg laag percentage baanopeningen.

Indien de baanopeningen van opleidingen en beroepen voor de slagersbranche met elkaar worden vergeleken, blijkt dat de opleidingen MBO/ LLW Consumptieve Techniek en VBO Consumptieve Techniek, die bestemd zijn voor het beroep van slager, meer baanopeningen hebben dan het beroep van slager. De uitwijkmogeijkheden voor deze

51. Op basis van de gebruikte gegevens van het Centraal Bureau voor de Statistiek kan geen nadere specificatie van het beroep van slager worden gegeven. 
twee opleidingen zijn gemiddeld. Een aanzienlijk deel van werkenden met een opleiding MBO/LLW Consumptieve Techniek (ongeveer een kwart) werkt als winkelier, handelaar, ondernemer, inkoper, etc. Een ander deel (een vijfde) werkt als voedings- en genotmiddelenbereider. Van de werkenden met een opleiding VBO Consumptieve Techniek is een significant gedeelte $(14 \%)$ werkzaam als keuken- en serveerpersoneel.

Tabel 4.20

Baanopeningen van opleidingen voor de slagersbranche, uitgesplitst naar uitbreidings- en vervangingsvraag, $1995-2000$

\begin{tabular}{lccc}
\hline Opleiding & $\begin{array}{c}\text { Uitbreidingsvraag } \\
\%\end{array}$ & $\begin{array}{c}\text { Vervangingsvraag } \\
\%\end{array}$ & $\begin{array}{c}\text { Baanopeningen } \\
\%\end{array}$ \\
& & & \\
MBO/LLW Consumptieve & 5 & 14 & 19 \\
Techniek & -13 & 14 & 9 \\
Basisonderwijs & -4 & 9 & 19 \\
VBO Consumptieve Techniek & -3 & 19 & 18 \\
VBO Verzorging & 3 & 14 & 17 \\
MBO/LLW Administratief & -1 & &
\end{tabular}

Bron: ROA

Opm.: Zie paragraaf 4.1 en hoofdstuk 1 voor de uitleg van de gebruikte begrippen en hun onderlinge samenhang. Hoofdstuk 1 geeft ook de grenswaarden van de kwalitatieve typeringen weer (laag, hoog, gemiddeld, e.d.).

Voor werkenden met één van de overige opleidingen, die relatief vaak terecht komen als verkoper in het banketbakkersbedrijf, zijn de uitwijkmogelijkheden in het algemeen hoog. De beroepen waarin deze werkenden terecht zijn heel divers: van verkooppersoneel tot bankemployés. De baanopeningen voor verkooppersoneel (tabel 4.19) zijn overigens aanzienlijk hoger dan de baanopeningen voor de genoemde opleidingen.

Tabel 4.21

Arbeidsmarktperspectieven van opleidingen voor de slagersbranche, 1995-2000

\begin{tabular}{lccc}
\hline Opleiding & $\begin{array}{c}\text { Instroom } \\
\%\end{array}$ & $\begin{array}{c}\text { Baanopeningen } \\
\%\end{array}$ & ITA \\
& & & \\
MBO/LLW Consumptieve & 19 & 19 & 1,06 \\
Techniek & 9 & 14 & 1,08 \\
Basisonderwijs & 26 & 9 & 1,29 \\
VBO Consumptieve Techniek & 7 & 19 & 0,99 \\
VBO Verzorging & 29 & 18 & 1,12 \\
MBO/LLW Administratief & 15 & 14 & 1,11 \\
gewogen gemiddelde & & &
\end{tabular}

Bron: ROA

Opm.: Zie paragraaf 4.1 en hoofdstuk 1 voor de uitleg van de gebruikte begrippen en hun onderlinge samenhang. Hoofdstuk 1 geeft ook de grenswaarden van de kwalitatieve typeringen weer (laag, hoog, gemiddeld, e.d.). 
Tabel 4.21 geeft de verwachte instroom, baanopeningen en arbeidsmarktperspectieven (ITA) weer. De indicator voor het arbeidsmarktperspectief (ITA) geeft aan dat de twee opleidingen die opleiden voor het slagersberoep, MBO/LLW Consumptieve Techniek en VBO Consumptieve Techniek, matige respectievelijk slechte perspectieven hebben. Voor de eerstgenoemde opleiding stijgen zowel de instroom als de baanopeningen met $19 \%$ over 5 jaar, terwijl voor de laatstgenoemde opleiding de instroom veel groter is dan de baanopeningen ( $26 \%$ versus $9 \%$ ). De werkenden die één van de overige opleidingen als opleidingsachtergrond hebben, zijn veelal in de verkoop werkzaam. Alleen de werkenden met een opleiding VBO Verzorging hebben een beter arbeidsmarktperspectief.

De verwachte instroom van de opleidingen voor de slagersbranche is $15 \%$, terwijl het verwachte aantal baanopeningen van de betreffende opleidingen slechts $14 \%$ van het totale aantal banen is. Het arbeidsmarktperspectief is met een ITA van 1,11 derhalve slechts matig. 


\section{Conclusies}

Dit rapport levert basisinformatie over de kenmerken en de arbeidsmarktpositie van werkenden in de ambachten die zijn aangesloten bij het Hoofdbedrijfsschap voor de Ambachten (HBA). Deze ambachten staan onder meer vermeld in bijlagen A en $B$ van dit rapport. Eén van de uitgangspunten van het rapport is om voor elk van de onderscheiden 38 ambachten de kenmerken en de arbeidsmarktpositie weer te geven van zowel schoolverlaters van min of meer ambachtelijke opleidingen als van werkenden in de ambachtelijke bedrijfsklassen of beroepen. De kenmerken en de arbeidsmarktpositie van schoolverlaters en werkenden hebben betrekking op hun opleidingsachtergrond, beroep, aansluiting tussen opleiding en beroep, kenmerken van hun baan (vast, flexibel, zelfstandig, voltijd, deeltijd), leeftijd, geslacht en etnische achtergrond. Met name voor de grotere ambachten (bijvoorbeeld het banketbakkersbedrijf en het kappersbedrijf) is er voldoende informatie beschikbaar om conclusies te trekken over de hierboven genoemde kenmerken en de arbeidsmarktpositie van schoolverlaters en werkenden. Voor de kleine ambachten (bijvoorbeeld het breibedrijf en het schoorsteenvegersbedrijf) geldt daarentegen dat de gegevens over de werkenden in deze ambachten vanwege restricties die het Centraal Bureau voor de Statistiek oplegt op het gebruik van de gegevens ${ }^{52}$, niet gepubliceerd kunnen worden of dat de instroom van schoolverlaters in deze ambachten te gering is om conclusies te trekken ${ }^{53}$.

In dit hoofdstuk zullen de kenmerken van werkenden in de bij het HBA aangesloten ambachten (inclusief de kleinere) worden vergeleken met de kenmerken van de totale beroepsbevolking. Vervolgens zal er nader worden ingegaan op de arbeidsmarktprofielen en de arbeidsmarktperspectieven van de ambachten.

\section{Kenmerken van werkenden in de ambachten}

Uit een vergelijkende analyse van werkenden in de ambachten ten opzichte van werkenden in de totale beroepsbevolking (tabel C.4 in appendix C) blijkt dat er relatief veel jongeren in de leeftijdscategorie tot dertig jaar in de ambachten werken. In de ambachten is $39 \%$ van de werkenden jonger dan dertig versus $29 \%$ voor de totale beroepsbevolking. Dit kan twee oorzaken hebben. Enerzijds is het mogelijk dat jongeren worden ingeschakeld in de ambachten, al dan niet op leerlingplaats, omdat zij een goedkope arbeidskracht betekenen voor de werkgever. Dit leidt op de langere termijn waarschijnlijk vaak tot een einde van de arbeidsrelatie, omdat met het vorderen van de leeftijd de arbeidskosten van de jongere stijgen. Anderzijds is het mogelijk dat werkgevers in de ambachten jongeren inschakelen omdat jongeren waarschijnlijk meer

52. De gegevens uit de Enquête Beroepsbevolking (EBB) van het CBS zijn afgerond op 500 en hebben een ondergrens van 2.500 .

53. In hoofdstuk 1 is aangegeven dat er met het oog op voldoende representativiteit een minimaal aantal schoolverlaters moet zijn (i.e. 25) voor het presenteren van de tabellen. 
dan gemiddeld bereid en in staat zijn nieuwe vakspecifieke vaardigheden te leren. Hierbij kunnen opleidingsplaatsen in het kader van het leerlingwezen van groot belang zijn. Het leerlingwezen neemt overigens in veel ambachten een prominente plaats in.

Voorts blijkt uit de vergelijking tussen werkenden in de ambachten en werkenden in de totale beroepsbevolking dat er relatief veel vrouwen in de ambachten werken. In de ambachten vormen vrouwen $45 \%$ van het aantal werkenden, terwijl dit $37 \%$ voor de totale beroepsbevolking is. Een verklaring hiervoor kan zijn dat er bij het HBA een aantal grote ambachten zijn aangesloten met typische 'vrouwenberoepen', zoals kappers, schoonheids- en voetverzorgers. Voorts werken er relatief veel allochtonen in de ambachten. $6 \%$ van de werkenden in de ambachten is allochtoon, terwijl dit slechts $3 \%$ is voor de totale beroepsbevolking.

De in hoofdstuk 1 genoemde kleinschaligheid van de ambachten wordt bevestigd door het relatief grote aantal zelfstandigen in de ambachten. In de ambachten werkt $21 \%$ als zelfstandige, tegenover $12 \%$ zelfstandigen in de totale beroepsbevolking. Ten slotte is het aandeel deeltijders in de ambachten relatief groot, namelijk $33 \%$. In de totale beroepsbevolking werkt slechts $26 \%$ als deeltijder, hetgeen mogelijk samenhangt met het eerder geconstateerde relatief grote aandeel vrouwen in de ambachten.

\section{Arbeidsmarktprofiel van ambachten}

Schema 5.1 categoriseert de ambachten op basis van twee indicatoren. Deze indicatoren bepalen tezamen het arbeidsmarktprofiel van een ambacht. De eerste indicator betreft het bestaan van een regulier bekostigde opleiding voor een ambacht. Zoals hierboven gesteld worden opleidingen in het voltijds onderwijs of in het leerlingwezen als regulier bekostigd beschouwd. Niet-regulier bekostigde opleidingen zijn bijvoorbeeld particuliere cursussen. Indien er een regulier bekostigde opleiding bestaat (zie hoofdstuk 2), duidt dit in elk geval op het bestaan van een formele relatie tussen de opleidingsachtergrond en de beroepsuitoefening van werkenden in het ambacht. Uit het schema blijkt dat de ongeveer de helft (19) van de ambachten die bij het HBA zijn aangesloten een regulier bekostigd opleidingenstelsel kent. De andere helft van de ambachten kent geen aparte regulier bekostigde opleiding voor de uitoefening van het betreffende ambacht.

De tweede indicator geeft de aansluiting tussen opleiding en beroep aan voor een ambacht. De beoordeling van de aansluiting tussen opleiding en beroep vindt onder andere plaats op grond van de meningen van de schoolverlaters die in het betreffende ambacht zijn gaan werken (zie hoofdstuk 2). Daarnaast wordt gekeken of een bepaalde ambachtelijke opleiding relatief vaak voorkomt in een ambacht (zie hoofdstuk 3). Voor het kappers-, schoonheidsverzorgings- en voetverzorgingsbedrijf blijken de schoolverlaters redelijk tevreden te zijn over de aansluiting tussen opleiding en beroep. Bovendien blijkt het merendeel van de werkenden in deze ambachten de voor het betreffende 
ambacht bestemde opleidingsachtergrond te hebben. Dit laatste blijkt ook te gelden voor het banketbakkers- en slagersbedrijf. Niettemin wordt de aansluiting bij deze ambachten slechts als matig beoordeeld, omdat de schoolverlaters die een opleiding tot brood- en banketbakker of slager hebben genoten of die in het banketbakkers- en slagersbedrijf werken ontevreden zijn over de aansluiting tussen opleiding en beroep. Ook voor het dakdekkers-, optiek-, parketvloerleggers- en glazenwassersbedrijf wordt de aansluiting tussen opleiding en beroep als matig beoordeeld. Voor deze ambachten geldt dat de werkenden in de betreffende ambachtelijke branches minstens één bepaalde veel voorkomende opleidingsachtergrond hebben, namelijk VBO Techniek voor het dakdekkersbedrijf en het parketvloerleggersbedrijf, en MBO/LLW Medisch Laboratorium/Optiek voor het optiekbedrijf. Voor het glazenwassersbedrijf is de aansluiting als matig beoordeeld, omdat er meerdere (algemene) opleidingen relatief vaak voorkomen onder de werkenden in dit ambacht, namelijk Basisonderwijs, VBO Verzorging, Mavo, onderbouw HAVO/NWO (zie hoofdstuk 3). De aansluiting tussen opleiding en beroep is in het glazenwassersbedrijf van voldoende niveau volgens het oordeel van de schoolverlaters (zie hoofdstuk 2). Zoals is gebleken, bestaat er geen aparte ambachtelijke opleiding voor het glazenwassersbedrijf. Dat is, afgaande op het oordeel van de schoolverlaters, ook niet noodzakelijk.

Op basis van de indeling van ambachten in schema 5.1 worden de arbeidsmarktprofielen van deze ambachten vastgesteld. Het arbeidsmarktprofiel van een ambacht is sterk als er een regulier bekostigde opleiding voor het ambacht bestaat én de aansluiting tussen opleiding en beroep redelijk/goed is. Derhalve kunnen de arbeidsmarktprofielen van het kappers-, schoonheidsverzorgings-, voetverzorgingsbedrijf als sterk beschouwd worden. In schema 5.1 zijn deze ambachten vet gedrukt. Voor het banketbakkers-, dakdekkers-, optiek-, parketvloerleggers- en slagersbedrijf wordt het arbeidsmarktprofiel als matig beoordeeld, omdat de schoolverlaters de aansluiting tussen opleiding en beroep als matig beoordelen. Deze ambachten zijn cursief gedrukt. Voorts is het arbeidsmarktprofiel van ambachten gering als er voor het betreffende ambacht geen regulier bekostigde opleiding bestaat. Het is echter niet uitgesloten dat er voor een bepaald ambacht een sterke informele relatie bestaat tussen werkenden met een bepaalde opleiding en de beroepsuitoefening in het betreffende ambacht. Overigens hebben met name veel kleine ambachten geen formeel opleidingenstelsel. Het arbeidsmarktprofiel is vooralsnog onduidelijk voor de ambachten die wel een regulier bekostigde opleiding hebben, maar waarvoor de aansluiting tussen opleiding en beroep onbekend is.

\section{Arbeidsmarktperspectieven voor de ambachten}

De arbeidsmarktperspectieven van de ambachten zijn beoordeeld op basis van de baanopeningen van de bijbehorende ambachtelijke beroepen en opleidingen over de periode van 1995 tot 2000 . Zowel de instroom van nieuwkomers op de arbeidsmarkt als het aantal baanopeningen bepalen het arbeidsmarktperspectief van een opleiding. De 
baanopeningen vallen uiteen in de uitbreidingsvraag en de vervangingsvraag ${ }^{54}$. Bij een slecht arbeidsmarktperspectief van een opleiding is er de komende jaren veel meer aanbod van nieuwkomers dan dat er baanopeningen zijn. Dit kan leiden tot een grotere werkloosheid, maar ook tot een verslechtering van de arbeidsmarktpositie waaronder een lagere beloning en meer tijdelijke contracten.

Schema 5.1

Indicatoren van het arbeidsmarktprofiel van ambachten

Regulier bekost. opleiding

ja

Aansluiting

\begin{tabular}{lll}
\hline redelijk/goed & $\begin{array}{l}\text { kappersbedrijf } \\
\text { schoonheidsverzorgingsbedrijf } \\
\text { voetverzorgingsbedrijf }\end{array}$ & \\
matig & $\begin{array}{l}\text { banketbakkersbedrijf } \\
\text { optiekbedsbedrijf } \\
\text { parketvloerleggersbedrijf } \\
\text { slagersbedrijf }\end{array}$ & glazenwassersbedrijf \\
& fijnkeramischbedrijf & \\
glasbewerkingsbedrijf & glazeniersbedrijf \\
goud- en zilversmidbedrijf & lederwarenambacht & \\
orth. schoentechnisch bedrijf & borduurbedrijf \\
schoenherstellersbedrijf & breibedrijf \\
schoorsteenvegersbedrijf & consumptie-ijsbereidingsbedrijf \\
tandtechnisch lab.bedrijf & fietsherstellersbedrijf \\
textielveredelingsbedrijf & grimeursbedrijf \\
uurwerkmakersbedrijf & modisterijbedrijf \\
& muziekinstrumentmakersbedrijf \\
& naaimachinebedrijf \\
& paramentenvervaardigingsbedrijf \\
& rolluiken- en \\
& markiezenmakersbedrijf \\
& tapijtherstellingsbedrijf \\
& toneelkappersbedrijf \\
& weverij en tapijtknoperij \\
& zadelmakersbedrijf \\
& zakkenstoppersbedrijf \\
\hline
\end{tabular}

Bron: ROA

Opm.: Bij de vet gedrukte ambachten is het arbeidsmarktprofiel sterk. Bij de cursief gedrukte ambachten is het arbeidsmarktprofiel matig. Bij de overige ambachten is het arbeidsmarktprofiel gering of onduidelijk. Zie ook hoofdstuk 1 voor de uitleg van de gebruikte begrippen.

De meeste onderzochte ambachten laten een negatieve uitbreidingsvraag en een positieve vervangingsvraag zien. De negatieve uitbreidingsvraag voor de ambachten duidt op een verwachte stagnatie of krimp van de totale werkgelegenheid in de ambachten voor 1995 tot 2000 . De negatieve uitbreidingsvraag wordt echter altijd meer dan gecompenseerd door de positieve vervangingsvraag. Het resulterende percentage verwachte baanopeningen voor zowel de beroepen als de opleidingen van deze am-

54. Zie hoofdstuk 1 voor uitleg van de gebruikte begrippen. 
bachten is derhalve altijd positief. Tegenover deze positieve percentages baanopeningen voor ambachtelijke beroepen en opleidingen staan echter de verwachte nog grotere percentages schoolverlaters met een ambachtelijke opleidingsachtergrond.

De verhouding tussen het aantal instromers op de arbeidsmarkt en het aantal baanopeningen bepaalt de Indicator Toekomstige Arbeidsmarktsituatie $(I T A)^{55}$. De arbeidsmarktperspectieven van de onderzochte ambachten worden weergegeven in schema 5.2. Hoe hoger de Indicator Toekomstige Arbeidsmarktsituatie, hoe slechter het toekomstig arbeidsmarktperspectief van een opleiding. Een waarde van ongeveer één duidt op een evenwichtige situatie (zie Borghans et al., 1995). Bij 1,00 of lager wordt de ITA als goed getypeerd, van 1,01 tot en met 1,05 als redelijk, van 1,06 tot en met 1,15 als matig en boven 1,15 als slecht. Uit het schema blijkt dat de arbeidsmarktperspectieven voor de schoolverlaters van ambachtelijke opleidingen in de meeste gevallen slechts matig zijn. Alleen in de optiekbranche heeft de bijbehorende opleiding (MBO Medische laboratorium/ Optiek) een goed arbeidsmarktperspectief.

Schema 5.2

Arbeidsmarktperspectieven voor de ambachten, 1995-2000

\begin{tabular}{lll}
\hline Typering & Ambacht & ITA \\
\hline goed & optiekbranche & 0,94 \\
redelijk & - & \\
matig & banketbakkersbranche \\
& $\begin{array}{l}\text { dakdekkersbranche } \\
\text { glazenwassers- en } \\
\text { schoonmakersbranche } \\
\text { kappersbranche } \\
\text { schoonheids- en } \\
\text { voetverzorgingsbranche } \\
\text { slagersbranche }\end{array}$ & 1,10 \\
& . & 1,10 \\
& & 1,07 \\
\end{tabular}

Bron: ROA

Opm.: Het arbeidsmarktperspectief is bepaald op basis van de Indicator Toekomstige Arbeidsmarktsituatie (ITA) van de aan de ambachten relateerde opleidingen (gewogen gemiddelde, zie hoofdstuk 5). Zie paragraaf 4.1 en hoofdstuk 1 voor de uitleg van de gebruikte begrippen en hun onderlinge samenhang. Hoofdstuk 1 geeft ook de grenswaarden van de kwalitatieve typeringen weer (goed, redelijk, matig, e.d.). Voor de niet opgenomen ambachten zijn geen arbeidsmarktperspectieven beschikbaar vanwege restricties die het Centraal Bureau voor de Statistiek oplegt op het gebruik van de gegevens.

Het matige arbeidsmarktperspectief van ambachtelijke opleidingen betekent dat werkgevers in de ambachten vooralsnog weinig moeite hebben om personeel te werven. Alleen voor de optiekbranche kan dit enigzins moeilijker zijn. Voor de ambachten met een gering arbeidsmarktprofiel dient echter gewezen te worden op het risico

55. Bij het berekenen van deze indicator wordt ook rekening gehouden met het aantal kortdurende werklozen en de substitutievraag (zie hoofdstuk 1). 
voor een adequate personeelsvoorziening bij een combinatie tussen dit geringe arbeidsmarktprofiel en een mogelijke algehele krapte op de arbeidsmarkt. Door een economische hausse van de Nederlandse economie kunnen tekorten ontstaan op alle segmenten van de Nederlandse arbeidsmarkt. De ambachten die een gering arbeidsmarktprofiel hebben, zullen dan de grootste problemen ondervinden bij het aantrekken van geschikte arbeidskrachten.

\section{Aanbevelingen voor vervolgonderzoek}

Tot slot volgen enige aanbevelingen die van belang zijn bij eventueel vervolgonderzoek. Ten eerste, om meer zicht te krijgen op de opleidingsachtergrond en de aansluiting tussen opleiding en beroep van schoolverlaters kan de schoolverlatersenquête worden uitgebreid met daadwerkelijk alle scholen die ambachtelijke opleidingen hebben. Daarnaast is het mogelijk een aparte enquête te houden onder alle werkenden in de ambachten met betrekking tot hun opleidingsachtergrond, beroepsuitoefening en overige kenmerken. Eventueel kan er ook een verzoek worden gedaan aan het Centraal voor de Statistiek om de Enquête Beroepsbevolking aan te passen ten behoeve van het uitgebreid vergaren van basisinformatie arbeidsmarkt en scholing voor de ambachten. Ten tweede, bij het opstellen van dit rapport is veel moeite gedaan de ambachten met de bestaande bedrijfsklassen- en beroepenclassificaties af te bakenen. Vervolgens bleken veel ambachten door de strikte afbakening relatief weinig werkenden of schoolverlaters te tellen, hetgeen het trekken van conclusies over deze werkenden en schoolverlaters bemoeilijkte voor een niet gering aantal ambachten. Derhalve is het zinvol te overwegen om bepaalde ambachten voor onderzoeksdoeleinden samen te voegen of deel te laten uitmaken van een grotere (eventueel niet-ambachtelijke) beroeps- of bedrijfsklasse. Ten derde, het leerlingwezen blijkt een prominente plaats in te nemen bij het vervullen van de opleidingsbehoefte van veel ambachten. In dit rapport wordt de instroom van schoolverlaters in het leerlingwezen geanalyseerd, terwijl de uitstroom van schoolverlaters uit het leerlingwezen onbekend is. Binnenkort zal het ROA beschikken over gegevens van de uitstroom van schoolverlaters uit het leerlingwezen. Het verdient aanbeveling deze gegevens te gebruiken in het eventuele vervolgonderzoek over de basisinformatie van arbeidsmarkt en scholing voor de ambachten. 


\section{Literatuur}

Borghans, L., A. de Grip, R. Dekker, A. Matheeuwsen, W. Smits en E. Willems (1995), Methodiek van het Informatiesysteem Onderwijs-Arbeidsmarkt 1995, ROA-W-1995/3, Maastricht.

Borghans, L., A. de Grip, en E. Willems (1995), Herijking ROA-Informatiesysteem OnderwijsArbeidsmarkt, ROA-R-1995/1, Maastricht.

CBS (1995), Enquête Beroepsbevolking 1994, Voorburg/ Heerlen.

CBS (1996), Enquête Beroepsbevolking 1995, Voorburg/ Heerlen.

EIM (1997), Jaarboek Ambacht 1996-1997, EIM / Ambachtsonderzoek, Zoetermeer.

LDC, Vereniging BVE, COLO en GSB, AOC-Raad (1993), Studiegids MBO en Leerlingwezen 1994, Alle opleidingen in het MBO en Leerlingwezen, Ten Brink Meppel bv, Meppel.

LDC, Vereniging BVE, COLO, AOC-Raad (1994), Studiegids MBO en Leerlingwezen 1995, Alle opleidingen in het MBO en Leerlingwezen, Ten Brink Meppel bv, Meppel.

ROA (1995), De arbeidsmarkt naar opleiding en beroep tot 2000, ROA-R-1995/3, Maastricht.

ROA (1996), De arbeidsmarkt naar opleiding en beroep tot 2000, Statistische bijlage, Actualisering 1996, ROA-R-1996/8B, Maastricht.

ROA (1996'), Schoolverlaters tussen onderwijs en arbeidsmarkt 1995, ROA-R-1996/3, Maastricht. 


\section{Bijlage A \\ Overzicht van de HBA-branches en de bijbehorende bedrijfsklassen volgens de Standaard Bedrijfsindeling}

(SBI93)

HBA-branche

1. Banketbakkersbedrijf

2. Borduurbedrijf

3. Breibedrijf

4. Consumptie-ijsbereidingsbedrijf

5. Dakdekkersbedrijf

6. Fietsherstellersbedrijf

7. Fijnkeramisch-bedrijf

8. Glasbewerkingsbedrijf
$\underline{\mathrm{SBI} 93}$ Titel

1581 Broodfabrieken, brood- en banketbakkerijen met verkoop in winkel

1582 Banketfabrieken en vervaardiging van beschuit en biscuit

5224,1 Detailhandel in brood en banket

1824 Vervaardiging van overige kleding en -toebehoren n.e.g.

1771 Vervaardiging van gebreide en gehaakte kousen en sokken

1772 Vervaardiging van gebreide en gehaakte artikelen (excl. kousen en sokken)

1552 Bereiding van consumptie-ijs

5530,3 IJssalons

4522 Dakdekken en bouwen van dakconstructies

5274 Reparatie t.b.v. particulieren n.e.g.

5248,5 Detailhandel in fietsen

2621 Vervaardiging van huishoudelijk en sieraardewerk

2624 Vervaardiging van overig technisch aardewerk

2625 Vervaardiging van overige niet-vuurvaste keramische produkten (niet voor de bouw)

2615 Vervaardiging en bewerking van overig glas

2611 Vervaardiging van vlakglas

2612 Vormen en bewerken van vlakglas 
9. Glazeniersbedrijf

10. Glazenwassersbedrijf

11. Goud- en zilversmidsbedrijf

12. Grimeursbedrijf

13. Kappersbedrijf

14. Kledingreparatiebedrijf

15. Korsettenvervaardigingsbedrijf

16. Lederwarenambacht

17. Maatoverhemdenbedrijf

18. Modisterijbedrijf

19. Muziekinstrumentmakersbedrijf

20. Naaimachinebedrijf

21. Optiekbedrijf
5153,3 Groothandel in vlakglas

2612 Vormen en bewerken van vlakglas

7470,1 Reiniging van gebouwen

5273 Reparatie van uurwerken en juweliersartikelen

3622 Vervaardiging van sieraden (excl. imitatie-)

9302,2 Schoonheidsverzorging, voetverzorgers en manicures

9232,3 Dienstverlening t.b.v. kunstbeoefening en organisatie van culturele evenementen

9302,1 Kappers

5274 Reparatie t.b.v. particulieren n.e.g.

1823 Vervaardiging van onder- en nachtkleding

1920 Vervaardiging van lederwaren (excl. kleding en schoeisel)

5271 Reparatie van schoeisel en lederwaren

1822 Vervaardiging van bovenkleding (excl. werkkleding en kleding van leer)

1823 Vervaardiging van onder- en nachtkleding

1824 Vervaardiging van overige kleding en- toebehoren n.e.g.

5274 Reparatie t.b.v. particulieren n.e.g.

3630 Vervaardiging van muziekinstrumenten

5245,7 Detailhandel in muziekinstrumenten

5274 Reparatie t.b.v. particulieren n.e.g.

5245,8 Detailhandel in naai- en breimachines

3340 Vervaardiging van optische instrumenten, foto- en 
filmapparatuur

5248,2 Detailhandel in optische artikelen

22. Orthopedisch schoentechnisch bedrijf

23. Paramentenvervaardigingsbedrijf

24. Parketvloerleggersbedrijf

25. Rolluikenenmarkiezenmakersbedrijf 26. Schoenherstellersbedrijf

27. Schoonheidsverzorgingsbedrijf

28. Schoorsteenvegersbedrijf

29. Slagersbedrijf

30. Tandtechnischlaboratoriumbedrijf

31. Tapijtherstellingsbedrijf

32. Textielveredelingsbedrijf

33. Toneelkappersbedrijf

34. Uurwerkmakersbedrijf

35. Voetverzorgingsbedrijf

36. Weverijentapijtknoperij

37. Zadelmakersbedrijf

38. Zakkenstopbedrijf
3310,2 Vervaardiging van medische apparaten en instrumenten en overige orthopedische en prothese-artikelen

1824 Vervaardiging van overige kleding en- toebehoren n.e.g.

4543 Afwerken van vloeren en wanden

4534 Overige bouwinstallatie

5271 Reparatievanschoeisel en lederwaren

9302,2 Schoonheidsverzorging, voetverzorgers en manicures

7470,1 Reiniging van gebouwen

5222,1 Detailhandel in vlees en vleeswaren

1511 Slachterijen (excl. pluimvee-)

3310,1 Tandtechnische bedrijven

5274 Reparatie t.b.v. particulieren n.e.g.

1730 Textielveredeling

9302,1 Kappers

9232,3 Dienstverlening t.b.v. kunstbeoefening en organisatie van culturele evenementen

5273 Reparatievanuurwerken en juweliersartikelen

9302,2 Schoonheidsverzorging, voetverzorgers en manicures

1751 Vervaardiging van vloerkleden en tapijt

172 Weven van textiel

1920 Vervaardigingvanlederwaren (excl.kledingenschoeisel)

1740 Vervaardigingvantextielwaren (excl.kleding)

5274 Reparatie t.b.v. particulieren n.e.g. 


\section{Bijlage B \\ Overzicht van beroepen die geheel of gedeeltelijk ambachtelijk zijn met de bijbehorende Standaard Beroepclassificatie (SBC92)}

\section{Banketbakkersbedrijf}

471 bakker ambachtelijk (excl. in-, verkoop)

47107 brood-, koek-, banketbakker, chocolademaker (ambachtelijk; excl in-, verkoop; middelbaar)

471 bakker ambachtelijk (incl. in-, verkoop; 0-9)

47105 brood-banketbakker (ambachtelijk; incl in-, verkoop)

471 bakker ambachtelijk (incl. in-, verkoop; $10 \mathrm{em}$ )

47114 leidinggevend brood-banketbakker (ambachtelijk; incl in-, verkoop)

\section{Borduurbedrijf}

272 appliqueerster confectie

272 (hand)borduurster

27204 confectie-, woning- en meubelstoffennaaister; kleermaker, zeil-, tenten, markiezen-, dekkledenmaker (excl patroontekenen, in-, verkoop)

272 borduurwerkster confectie

27204 confectie-, woning- en meubelstoffennaaister; kleermaker, zeil-, tenten, markiezen-, dekkledenmaker (excl patroontekenen, in-, verkoop)

272 festoneerster linnengoed, confectie

27204 confectie-, woning- en meubelstoffennaaister; kleermaker, zeil-, tenten, markiezen-, dekkledenmaker (excl patroontekenen, in-,verkoop)

272 plisseerster confectie

27204 confectie-, woning- en meubelstoffennaaister; kleermaker, zeil-, tenten, markiezen-, dekkledenmaker (excl patroontekenen, in-, verkoop)

\section{Breibedrijf}

4. Consumptie-ijsbereidingsbedrijf

271 consumptie-ijsbereider

27112 mechanisch operator glas-, aardewerk-, papier-, textiel-, voedings- en genotmiddelen-, procesindustrie

\section{Dakdekkersbedrijf}

262 dakdekker bedekking aanbrengen, renoveren (elementen)

26211 betontimmerman, parketvloerenlegger, monteur systeembouw; bouwvaktimmerman (lager)

262 dakdekker bedekking aanbrengen, renoveren

26219 dakdekker (geen elementen)

262 dakdekker leien dak

26219 dakdekker

262 dakdekker mastiek 
26219 dakdekker

262 dakdekker stro en riet

26219 dakdekker

6. Fietsherstellersbedrijf

265 fietsenmaker (onderhoud, reparatie)

26505 rijwiel-, motorrijwiel-, bromfietshersteller, hulpautomonteur

7. Fijnkeramisch-bedrijf

111 aardkneder aardewerkfabriek

11117 produktiemedewerker industrie (eenvoudige machine bedienen)

111 aardewerkarbeider aardewerk slijpen

11117 produktiemedewerker industrie (eenvoudige machine bedienen)

111 aardewerkarbeider znd

11117 produktiemedewerker industrie (eenvoudige machine bedienen)

111 aardewerkarbeider aardewerk uitzetten

11117 produktiemedewerker industrie (eenvoudige machine bedienen)

111 aardewerkarbeider aardewerk sorteren

11134 postsorteerder ptt, grondstof-, produktensorteerder, meteropnemer water-, energiebedrijf

271 aardewerkarbeider aardewerk draaien (handmatig)

27103 aardewerkvormer, -draaier (hand)

271 aardewerkarbeider aardewerk gieten

27109 machinebediende glas-, aardewerk-, papier-, textiel-, voedings- en genotmiddelen-, procesindustrie

271 aardewerkarbeider aardewerk vormen

27109 machinebediende glas-, aardewerk-, papier-, textiel-, voedings- en genotmiddelen-, procesindustrie

271 aardewerkarbeider aardewerk persen

27109 machinebediende glas-, aardewerk-, papier-, textiel-, voedings- en genotmiddelen-, procesindustrie

271 aardewerkarbeider aardewerk draaien (machinaal)

27109 machinebediende glas-, aardewerk-, papier-, textiel-, voedings- en genotmiddelen-, procesindustrie

271 aardewerkarbeider aardewerk schilderen (handmatig)

27115 sigarenmaker, glas- en aardewerkschilder, nettenboeter (handmatig)

271 aardewerkarbeider aardewerk decoreren (handmatig)

27115 sigarenmaker, glas- en aardewerkschilder, nettenboeter (handmatig)

464 aardewerkarbeider aardewerk modelleren

46413 gereedschapssmid, vormenmaker, modelmaker gips

8. Glasbewerkingsbedrijf

464 glasbew. (polijsten, slijpen, snijden ed glasfabriek, -handel)

46411 fijnbankwerker, uurwerkmaker, -reparateur, optisch glasslijper, (glas)instrumentmaker; gereedschapsmaker (middelbaar) 


\section{Glazeniersbedrijf}

462 glazenier (geen kunstenaar)

46217 glas in lood-zetter

462 glazenier glas-in-lood

46217 glas in lood-zetter

754 glazenierkunst

75415 beeldend kunstenaar; museummedewerker presentaties; mode-ontwerper; decor-, reclame-, grafisch ontwerper (hoger)

10. Glazenwassersbedrijf

111 glazenwasser

11133 glazenwasser, interieurverzorger, keukenknecht, medewerker huishoudelijke dienst

11. Goud-en zilversmidsbedrijf

464 goud- en zilverbewerker (massafabricage)

46421 goud- en zilversmid (massa-fabricage)

464 goud- en zilverreparateur

46421 goud- en zilversmid (massa-fabricage)

464 goud- en zilversmid (sieraden bewerken massafabricage)

46421 goud- en zilversmid (massa-fabricage)

464 goud- en zilversmid edelmetaal (massafabricage)

46421 goud- en zilversmid (massa-fabricage)

754 goud- en zilversmid kunst

75415 beeldend kunstenaar; museummedewerker presentaties; mode-ontwerper; decor-, reclame-, grafisch ontwerper (hoger)

\section{Grimeursbedrijf}

572 grimeur

57212 kapper, pruikenmaker, grimeur, schoonheidsspecialist

\section{Kappersbedrijf}

572 kapper

57212 kapper, pruikenmaker, grimeur, schoonheidsspecialist

$372 \quad$ kappershulp

37210 manicure, pedicure, kappershulp, schoonheidsmasseur sauna

14. Kledingreparatiebedrijf

11116 kledingplakker confectie

$271 \quad$ kledingmazer

27105 weefselhersteller, stopster, nopster

271 kledingstopper

27105 weefselhersteller, stopster, nopster

$272 \quad$ kleermaker $z$ nd

27204 confectie-, woning- en meubelstoffennaaister; kleermaker, zeil-, tenten, markiezen-, dekkledenmaker (excl patroontekenen, in-, verkoop) 
272 kleermaker maatkleding (excl patroontekenen; excl in-, verkoop)

27204 confectie-, woning- en meubelstoffennaaister; kleermaker, zeil-, tenten markiezen-, dekkledenmaker (excl patroontekenen, in-, verkoop)

\section{Korsettenvervaardigingsbedrijf}

472 korsettencoupeur confectie

47211 modelnaaister, patroonmaker (kleding)

272 korsettennaaister confectie

27204 confectie-, woning- en meubelstoffennaaister; kleermaker, zeil-, tenten, markiezen-, dekkledenmaker (excl patroontekenen, in-, verkoop)

272 korsettenstikster confectie

27204 confectie-, woning- en meubelstoffennaaister; kleermaker, zeil-, tenten, markiezen-, dekkledenmaker (excl patroontekenen, in-, verkoop)

16. Lederwarenambacht

272 lederwarenmaker (excl kleding; incl in-, verkoop)

27206 schoenfabrieksarbeider; schoenhersteller, lederwarenmaker (excl kleding, in-, verkoop)

272 lederwarenmaker (excl kleding; $z$ nd)

27206 schoenfabrieksarbeider; schoenhersteller, lederwarenmaker (excl kleding, in-, verkoop)

472 lederwarenmaker (excl kleding; incl in-, verkoop)

47208 schoenhersteller, lederwarenmaker (excl kleding, incl in-, verkoop)

\section{Maatoverhemdenbedrijf}

472 kleermaker maatkleding (incl patroontekenen; incl in-

47203 (bont)kleermaker, zeil-, tenten-, markiezen-, dekkledenmaker (incl patroontekenen, in-, verkoop)

472 kleermaker maatkleding (incl patroontekenen; excl in-

47204 kleermaker (excl bont), zeil-, tenten-, markiezen-, dekkledenmaker (incl patroontekenen, excl in-, verkoop)

472 kleermaker maatkleding (excl patroontekenen; incl in-

47210 kleermaker maatkleding (excl patroontekenen; incl in- en verkoop)

272 overhemdennaaister confectie

27204 confectie-, woning- en meubelstoffennaaister; kleermaker, zeil-, tenten, markiezen-, dekkledenmaker (excl patroontekenen, in-, verkoop)

272 overhemdenstikster confectie

27204 confectie-, woning- en meubelstoffennaaister; kleermaker, zeil-, tenten, markiezen-, dekkledenmaker (excl patroontekenen, in-, verkoop)

18. Modisterijbedrijf

272 modist hoeden, petten

27204 confectie-, woning- en meubelstoffennaaister; kleermaker, zeil-, tenten, markiezen-, dekkledenmaker (excl patroontekenen, in-, verkoop)

19. Muziekinstrumentmakersbedrijf

111 muziekinstrumentenmaker elektronisch (elementair)

11118 produktiemedewerker industrie (samenstellen; geen houtwaren, plastic-, rubberartikelen)

267 muziekinstrumentenmaker elektronisch (lager)

26705 wikkelaar ankers, spoelen; samensteller elektronische apparatuur 
461 muziekinstrumentenmaker hout, metaal (incl in-, verkoo

46102 muziekinstrumentenmaker-reparateur (incl in-, verkoop)

461 muziekinstrumentenreparateur (incl in-, verkoop)

46102 muziekinstrumentenmaker-reparateur (incl in-, verkoop)

461 muziekinstrumentenstemmer (geen pianostemmer; incl in-

46102 muziekinstrumentenmaker-reparateur (incl in-, verkoop)

461 muziekinstrumentenmaker hout, metaal (excl in-, verkoop)

46103 muziekinstrumentenmaker-reparateur (excl in-, verkoop)

461 muziekinstrumentenreparateur (excl in-, verkoop)

46103 muziekinstrumentenmaker-reparateur (excl in-, verkoop)

461 muziekinstrumentenstemmer (geen pianostemmer; excl in-verk.)

46103 muziekinstrumentenmaker-reparateur (excl in-, verkoop)

\section{Naaimachinebedrijf}

465 machinesteller (incl installatie)

46516 onderhoudsmonteur kantoor-, huishoudnaaimachines, motoren; motormonteur, tuiger, takelaar

\section{Optiekbedrijf}

\section{4 optisch glasslijper}

46411 fijnbankwerker, uurwerkmaker, -reparateur, optisch glasslijper, (glas)instrumentmaker; gereedschapsmaker (middelbaar)

464 optisch instrumentreparateur

46411 fijnbankwerker, uurwerkmaker, -reparateur, optisch glasslijper, (glas)instrumentmaker; gereedschapsmaker (middelbaar)

464 optiekmaker

46411 fijnbankwerker, uurwerkmaker, -reparateur, optisch glasslijper, (glas)instrumentmaker; gereedschapsmaker (middelbaar)

464 optisch instrumentmaker

46411 fijnbankwerker, uurwerkmaker, -reparateur, optisch glasslijper, (glas)instrumentmaker; gereedschapsmaker (middelbaar)

493 optometrist (incl in-, verkoop)

49309 audicien, opticien (incl in-, verkoop)

493 opticien (incl in-, verkoop)

49309 audicien, opticien (incl in-, verkoop)

493 opticien (excl in-, verkoop)

49311 eeg-, ecg-, hart-, longfunctieassistent (middelbaar); leerling-radiologisch laborant; audicien, opticien (excl in-, verkoop)

493 optometrist (excl in-, verkoop)

49311 eeg-, ecg-, hart-, longfunctieassistent (middelbaar); leerling-radiologisch laborant; audicien, opticien (excl in-, verkoop)

493 opticien (znd)

49311 eeg-, ecg-, hart-, longfunctieassistent (middelbaar); leerling-radiologisch laborant; audicien, opticien (excl in-, verkoop) 
493 optometrist (znd)

49311 eeg-, ecg-, hart-, longfunctieassistent (middelbaar); leerling-radiologisch laborant; audicien, opticien (excl in-, verkoop)

\section{Orthopedisch schoentechnisch bedrijf}

493 orthopedisch schoenmaker

49308 orthopedisch schoenmaker

493 orthopedisch schoentechnicus

49308 orthopedisch schoenmaker

693 orthopedisch maatnemer en modelmaker

69304 orthopedisch maatnemer en modelmaker

\section{Paramentenvervaardigingsbedrijf}

\section{2 sierstikselstikster}

27204 confectie-, woning- en meubelstoffennaaister; kleermaker, zeil-, tenten markiezen-, dekkledenmaker (excl patroontekenen, in-, verkoop)

272 sierstikster

27204 confectie-, woning- en meubelstoffennaaister; kleermaker, zeil-, tenten, markiezen-, dekkledenmaker (excl patroontekenen, in-, verkoop)

272 linnenknipper

27204 confectie-, woning- en meubelstoffennaaister; kleermaker, zeil-, tenten, markiezen-, dekkledenmaker (excl patroontekenen, in-, verkoop)

272 linnensnijder

27204 confectie-, woning- en meubelstoffennaaister; kleermaker, zeil-, tenten, markiezen-, dekkledenmaker (excl patroontekenen, in-, verkoop)

\section{Parketvloerleggersbedrijf}

262 parketlegger

26211 betontimmerman, parketvloerenlegger, monteur systeembouw; bouwvaktimmerman (lager)

262 parketteur parketvloeren leggen

26211 betontimmerman, parketvloerenlegger, monteur systeembouw; bouwvaktimmerman (lager)

262 parketvloerlegger

26211 betontimmerman, parketvloerenlegger, monteur systeembouw; bouwvaktimmerman (lager)

\section{Rolluiken en markiezenmakersbedrijf}

262 rolluikenmonteur

26211 betontimmerman, parketvloerenlegger, monteur systeembouw; bouwvaktimmerman (lager)

272 markiezenbekleder (excl in-, verkoop)

27204 confectie-, woning- en meubelstoffennaaister; kleermaker, zeil-, tenten, markiezen-, dekkledenmaker (excl p

272 markiezenmaker (excl patroontekenen; excl in- en verkoop)

27204 confectie-, woning- en meubelstoffennaaister; kleermaker, zeil-, tenten, markiezen-, dekkledenmaker (excl p

462 rolluikentimmerman 
46213 decor-, markiezen-, rolluikentimmerman; bouwvaktimmerman (middelbaar)

462 markiezentimmerman

46213 decor-, markiezen-, rolluikentimmerman; bouwvaktimmerman (middelbaar)

472 markiezenmaker (incl patroontekenen; incl in- en verkoop)

47203 (bont)kleermaker, zeil-, tenten-, markiezen-, dekkledenmaker (incl patroontekenen, in-, verkoop)

472 markiezenmaker (incl patroontekenen; excl in- en verkoop)

47204 kleermaker (excl bont), zeil-, tenten-, markiezen-, dekkledenmaker (incl patroontekenen, excl in-, verkoop)

472 markiezenbekleder (incl in-, verkoop)

47207 bontkleermaker, zeil-, tenten-, markiezen-, dekkledenmaker (excl patroontekenen, incl in-, verkoop)

472 markiezenmaker (excl patroontekenen; incl in- en verkoop)

47207 bontkleermaker, zeil-, tenten-, markiezen-, dekkledenmaker (excl patroontekenen, incl in-, verkoop)

\section{Schoenherstellersbedrijf}

272 schoenmaker reparatie (excl in-, verkoop)

27206 schoenfabrieksarbeider; schoenhersteller, lederwarenmaker (excl kleding, in-, verkoop)

272 schoenmaker schoenfabriek

27206 schoenfabrieksarbeider; schoenhersteller, lederwarenmaker (excl kleding, in-, verkoop)

272 schoenreparateur (excl in-, verkoop)

27206 schoenfabrieksarbeider; schoenhersteller, lederwarenmaker (excl kleding, in-, verkoop)

272 schoenstikker

27206 schoenfabrieksarbeider; schoenhersteller, lederwarenmaker (excl kleding, in-, verkoop)

472 schoenmaker reparatie (incl in-, verkoop)

47208 schoenhersteller, lederwarenmaker (excl kleding, incl in-, verkoop)

472 schoenreparateur (incl in-, verkoop)

47208 schoenhersteller, lederwarenmaker (excl kleding, incl in-, verkoop)

472 schoenmaker maatschoeisel

47212 maatschoenmaker

\section{Schoonheidsverzorgingsbedrijf}

572 schoonheidsmasseuse (geen badgelegenheid, sauna)

57212 kapper, pruikenmaker, grimeur, schoonheidsspecialist

572 schoonheidsspecialiste

57212 kapper, pruikenmaker, grimeur, schoonheidsspecialist

572 huidverzorgster

57212 kapper, pruikenmaker, grimeur, schoonheidsspecialist 


\section{Schoorsteenvegersbedrijf}

111 schoorsteenveger particuliere woningen

11111 schoonmaker machines, gebouwen, installaties, produkten (geen walserij-, gieterij-produkten)

\section{Slagersbedrijf}

111 slachterij-arbeider (geen slachter-, uitbeners- of snijderswerk

11117 produktiemedewerker industrie (eenvoudige machine bedienen)

271 slagersgezel detailhandel (incl verkoop)

27101 slager-verkoper (lager)

271 slagersbediende-verkoper

27101 slager-verkoper (lager)

271 slagersknecht detailhandel (incl verkoop)

27101 slager-verkoper (lager)

271 slager-verkoper detailhandel (lager; 0-9)

27101 slager-verkoper (lager)

271 slagersknecht-verkoper detailhandel

27101 slager-verkoper (lager)

271 slager-verkoper in winkel (lager; 0-9)

27101 slager-verkoper (lager)

271 slagersknecht detailhandel (excl verkoop)

27107 slachter, slachterij-arbeider, worst-vleeswarenmaker; visfileerder, -snijder, schaaldierenpeller

271 slagersknecht slachterij en vleeswarenfabriek

27107 slachter, slachterij-arbeider, worst-vleeswarenmaker; visfileerder, -snijder, schaaldierenpeller

271 slagersgezel detailhandel (excl verkoop)

27107 slachter, slachterij-arbeider, worst-vleeswarenmaker; visfileerder, -snijder, schaaldierenpeller

271 slagersleerling slachterij en vleeswarenfabriek

27107 slachter, slachterij-arbeider, worst-vleeswarenmaker; visfileerder, -snijder, schaaldierenpeller

271 slachthuisbediende

27107 slachter, slachterij-arbeider, worst-vleeswarenmaker; visfileerder, -snijder, schaaldierenpeller

271 slager pluimvee (geen verkoop)

27107 slachter, slachterij-arbeider, worst-vleeswarenmaker; visfileerder, -snijder, schaaldierenpeller

271 slager fabriek, hotel, inrichting

27107 slachter, slachterij-arbeider, worst-vleeswarenmaker; visfileerder, -snijder, schaaldierenpeller

271 slachthuisknecht

27107 slachter, slachterij-arbeider, worst-vleeswarenmaker; visfileerder, -snijder, schaaldierenpeller 
27107 slachter, slachterij-arbeider, worst-vleeswarenmaker; visfileerder, -snijder, schaaldierenpeller

271 slager vee (geen verkoop)

27107 slachter, slachterij-arbeider, worst-vleeswarenmaker; visfileerder, -snijder, schaaldierenpeller

271 slager detailhandel (geen verkoop)

27107 slachter, slachterij-arbeider, worst-vleeswarenmaker; visfileerder, -snijder, schaaldierenpeller

271 slager horecabedrijf

27107 slachter, slachterij-arbeider, worst-vleeswarenmaker; visfileerder, -snijder, schaaldierenpeller

471 slager-verkoper detailhandel (middelbaar; 0-9)

47106 slager-verkoper (middelbaar)

471 slager-verkoper in winkel (middelbaar; 0-9)

47106 slager-verkoper (middelbaar)

471 slager-verkoper detailhandel (10 em)

47115 leidinggevend slager-verkoper

471 slager-verkoper in winkel (10 em)

47115 leidinggevend slager-verkoper

30. Tandtechnisch laboratoriumbedrijf

492 tandartsassistente

49202 doktersassistent

493 tandtechnicus

49305 tandtechnicus

493 tandprotheticus

49305 tandtechnicus

31. Tapijtherstellingsbedrijf

271 tapijtafwerker

27105 weefselhersteller, stopster, nopster

271 tapijtschoonmaker (noppen, stoppen controleren)

27105 weefselhersteller, stopster, nopster

271 tapijtfranjeerder

27109 machinebediende glas-, aardewerk-, papier-, textiel-, voedings- en genotmiddelen-, procesindustrie

271 tapijtzomer

27109 machinebediende glas-, aardewerk-, papier-, textiel-, voedings- en genotmiddelen-, procesindustrie

272 tapijtreiniger wasserij

27202 hoofd wasserij, wasser, perser, ontvlekker wasserij

471 tapijtknoper (handmatig)

47108 handwever (stof, tapijt, kant) 
32. Textielveredelingsbedrijf

271 textielveredelaar (excl scheren, persen)

27112 mechanisch operator glas-, aardewerk-, papier-, textiel-, voedings- en genotmiddelen-, procesindustrie

271 textielverver

27112 mechanisch operator glas-, aardewerk-, papier-, textiel-, voedings- en genotmiddelen-, procesindustrie

468 textieldrukker

46808 hoog-, diep-, offset-, blok-, textieldrukker

468 textielspuiter spritzdruck

46808 hoog-, diep-, offset-, blok-, textieldrukker

\section{Toneelkappersbedrijf}

572 toneelkapper

57212 kapper, pruikenmaker, grimeur, schoonheidsspecialist

\section{Uurwerkmakersbedrijf}

464 uurwerkreparateur-verkoper

46406 uurwerkreparateur-verkoper

464 uurwerkmaker

46411 fijnbankwerker, uurwerkmaker, -reparateur, optisch glasslijper, (glas)instrumentmaker; gereedschapsmaker (middelbaar)

464 uurwerkreparateur

46411 fijnbankwerker, uurwerkmaker, -reparateur, optisch glasslijper, (glas)instrumentmaker; gereedschapsmaker (middelbaar)

\section{Voetverzorgingsbedrijf}

372 voetverzorger

37210 manicure, voetverzorger, kappershulp, schoonheidsmasseur sauna

\section{Weverij en tapijtknoperij}

271 wever gripperweefgetouw

27109 machinebediende glas-, aardewerk-, papier-, textiel-, voedings- en genotmiddelen-, procesindustrie

471 wever handgetouw

47108 handwever (stof, tapijt, kant)

471 tapijtknoper (handmatig)

47108 handwever (stof, tapijt, kant)

37. Zadelmakersbedrijf

272 zadelmaker (excl in-, verkoop)

27206 schoenfabrieksarbeider; schoenhersteller, lederwarenmaker (excl kleding, in-, verkoop)

272 zadelmaker (znd)

27206 schoenfabrieksarbeider; schoenhersteller, lederwarenmaker (excl kleding, in-, verkoop)

472 zadelmaker (incl in-, verkoop)

47208 schoenhersteller, lederwarenmaker (excl kleding, incl in-, verkoop) 
38. Zakkenstopbedrijf

272 zakkenmaakster confectie

27204 confectie-, woning- en meubelstoffennaaister; kleermaker, zeil-, tenten, markiezen-, dekkledenmaker (excl patroontekenen, in-, verkoop)

272 zakkenstikster confectie

27204 confectie-, woning- en meubelstoffennaaister; kleermaker, zeil-, tenten, markiezen-, dekkledenmaker (excl patroontekenen, in-, verkoop) 


\section{Bijlage C \\ Gegevens over schoolverlaters en werkenden in de ambachten en de totale beroepsbevolking}

Tabel C.1

Bestemming van schoolverlaters in de schoolverlatersenquête

\begin{tabular}{lr} 
Bestemming & $\%$ \\
\hline scholier/ student & 66 \\
betaald werk (excl. leerlingwezen) & 20 \\
leerlingwezen/in-service & 9 \\
werkloos & 3 \\
anders & 2 \\
totaal & 100
\end{tabular}

Bron: ROA

Opm.: De gepresenteerde gegevens hebben betrekking op schoolverlaters met en zonder diploma.

Tabel C.2

Aansluiting tussen opleiding en beroep van werkende schoolverlaters in de schoolverlatersenquête (excl. leerlingwezen)

\begin{tabular}{|c|c|c|c|}
\hline Variable & $\begin{array}{c}\text { Benutting } \\
\%\end{array}$ & $\underset{\%}{\text { Aansluiting }}$ & $\begin{array}{l}\text { Vakrichting } \\
\%\end{array}$ \\
\hline
\end{tabular}

vereist niveau:

lager

hetzelfde

37

hoger

60

aansluiting:

matig/slecht

34

goed/voldoende

66

vakrichting vereist:
ja, dezelfde
37
$\mathrm{ja}$, een andere
7
nee
56

Bron: ROA

Opm.: Zie voor de definitie van bijvoorbeeld 'onderbenutting' de begrippenlijst in hoofdstuk 1. 
Tabel C.3

Diplomabezit van alle schoolverlaters in de schoolverlatersenquête

Schoolverlaters van alle opleidingen

Indicator

met diploma

9

Bron: ROA

Opm.: Zie de begrippenlijst in hoofdstuk 1 voor de uitleg van de indicator voor diplomabezit.

Tabel C.4

Kenmerken van werkenden in de ambachten en in de totale beroepsbevolking

\begin{tabular}{lcc}
\hline Kenmerk & $\begin{array}{c}\text { Ambachten } \\
\%\end{array}$ & $\begin{array}{c}\text { Totaal } \\
\%\end{array}$ \\
\hline leeftijd & & \\
jonger (15-29 jr.) & 39 & 29 \\
middelbaar (30-49 jr.) & 49 & 56 \\
ouder (50-64 jr.) & 12 & 15 \\
geslacht & & \\
man & 55 & 63 \\
vrouw & 45 & 37 \\
etniciteit & & \\
Nederlands & 89 & 92 \\
allochtoon & 6 & 3 \\
overig & 5 & 5 \\
positie werkkring & & \\
vast ( 1 jr.) & 73 & 81 \\
flexibel (<1 jr.) & 7 & 12 \\
zelfstandig & 21 & \\
lengte werkweek & & 74 \\
voltijd (>32 uur) & & 26 \\
deeltijd ( $\leq 32$ uur) & 67 & \\
\hline
\end{tabular}

Bron: CBS/ROA

Opm.: De ambachten hebben betrekking op de ambachtelijke bedrijfsklassen van bijlage A. Zie hoofdstuk 1 voor de uitleg van de begrippen 'allochtoon' en 'flexibele arbeidsrelatie'. 